Portland State University

PDXScholar

Urban Studies and Planning Faculty

Nohad A. Toulan School of Urban Studies and

Publications and Presentations

Planning

$1-2011$

\title{
Evaluation of Bike Boxes at Signalized Intersections
}

Jennifer Dill

Portland State University, jdill@pdx.edu

Christopher M. Monsere

Portland State University, monsere@pdx.edu

Nathan McNeil

Portland State University

Follow this and additional works at: https://pdxscholar.library.pdx.edu/usp_fac

Part of the Transportation Commons, Urban Studies Commons, and the Urban Studies and Planning Commons

Let us know how access to this document benefits you.

\section{Citation Details}

Jennifer Dill, Christopher Monsere, and Nathan McNeil. Evaluation of Bike Boxes at Signalized Intersections. OTREC-RR-11-06. Portland, OR: Transportation Research and Education Center (TREC), 2011. http://dx.doi.org/10.15760/trec.138

This Report is brought to you for free and open access. It has been accepted for inclusion in Urban Studies and Planning Faculty Publications and Presentations by an authorized administrator of PDXScholar. Please contact us if we can make this document more accessible: pdxscholar@pdx.edu. 


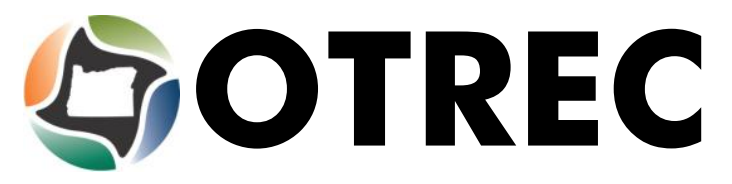

FINAL REPORT

\section{EVALUATION OF BIKE BOXES \\ AT SIGNALIZED INTERSECTIONS}

OTREC-RR-11-06 January 2011 



\title{
EVALUATION OF BIKE BOXES AT SIGNALIZED INTERSECTIONS
}

OTREC-RR-11-06

\author{
by \\ Jennifer Dill \\ Christopher Monsere \\ Nathan McNeil \\ Portland State University
}

for

City of Portland

Office of Transportation

Oregon Transportation Research and Education Consortium (OTREC)

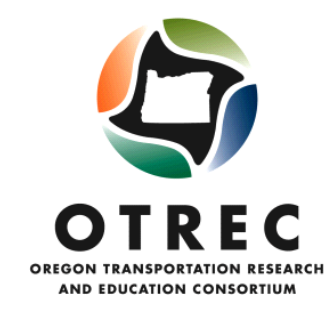

January 2011 



\section{Technical Report Documentation Page}

\begin{tabular}{|l|l|l}
\hline $\begin{array}{l}\text { 1. Report No. } \\
\text { OTREC-RR-11-06 }\end{array}$ & 2. Government Accession No. & 3. \\
\hline
\end{tabular}

Evaluation of Bike Boxes at Signalized Intersections

Jennifer Dill, Christopher Monsere, Nathan McNeil

9. Performing Organization Name and Address

Portland State University

PO Box 751

Portland, OR 97207

12. Sponsoring Agency Name and Address

Oregon Transportation Research

and Education Consortium (OTREC)

P.O. Box 751

Portland, Oregon 97207

15. Supplementary Notes
3. Recipient's Catalog No.

5. Report Date

January 2011

6. Performing Organization Code

8. Performing Organization Report No.

10. Work Unit No. (TRAIS)

11. Contract or Grant No.

13. Type of Report and Period Covered

14. Sponsoring Agency Code

\section{Abstract}

This report presents a before-after study of bike boxes at 10 signalized intersections in Portland, Oregon. The bike boxes, also known as advanced stop lines or advanced stop boxes, were installed to increase visibility of cyclists and reduce conflicts between motor vehicle and cyclists, particularly in potential "right-hook" situations. Before and after video were analyzed for seven intersections with green bike boxes, three intersections with uncolored bike boxes, and two control intersections. User perceptions were measured through surveys of cyclists passing through five of the bike box intersections and of motorists working downtown, where the boxes were concentrated. Both the observations and survey of motorists found a high rate of compliance and understanding of the markings. Overall, $73 \%$ of the stopping motor vehicles did not encroach at all into the bike box. Both motor vehicle and bicycle encroachment in the pedestrian crosswalk fell significantly at the bike box locations compared to the control intersections. The bike boxes had mixed effects on the motorists' encroachment in the bicycle lane. The number of observed conflicts at the bike box locations decreased, while the total number of cyclists and motor vehicles turning right increased. Negative-binomial models based upon the data predict fewer conflicts with the boxes, particularly as right-turning motor vehicle volumes increase. Observations of yielding behavior at two bike box and one control intersection found an improvement in motorists yielding to cyclists at the bike box locations. Differences in the traffic volumes and location contexts make firm conclusions about the effects of green coloring of the boxes difficult. Higher shares of surveyed motorists felt that the bike boxes made driving safer rather than more dangerous, even when the sample was narrowed to respondents who were not also cyclists. Over three-quarters of the surveyed cyclists thought that the boxes made the intersection safer.

17. Key Words

Bike boxes; Road safety; Pavement marking; Before-after study
18. Distribution Statement

No restrictions. Copies available from OTREC: www.otrec.us

19. Security Classification (of this report)

20. Security Classification (of this page)
Unclassified

21. No. of Pages
122

Unclassified

Unclassified

22. Price 


\section{ACKNOWLEDGEMENTS}

This research was funded by Oregon Transportation Research and Education Consortium (OTREC) and the City of Portland. Bob Kellett and William Farley assisted in data reduction. Senior Trooper Jeff Willis, Oregon State Police, provided feedback on the friction testing results.

\section{DISCLAIMER}

The contents of this report reflect the views of the authors, who are solely responsible for the facts and the accuracy of the material and information presented herein. This document is disseminated under the sponsorship of the U.S. Department of Transportation University Transportation Centers Program and the City of Portland in the interest of information exchange. The U.S. Government and the City of Portland assume no liability for the contents or use thereof. The contents do not necessarily reflect the official views of the U.S. Government and the City of Portland. This report does not constitute a standard, specification, or regulation. 


\section{TABLE OF CONTENTS}

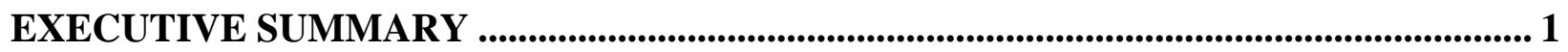

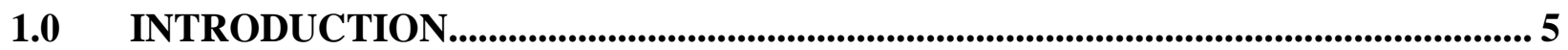

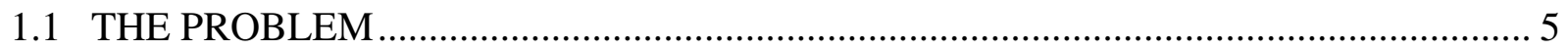

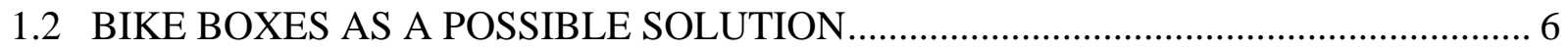

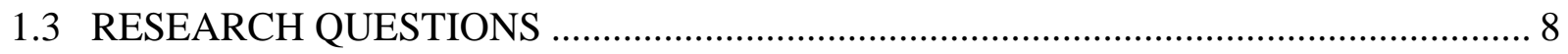

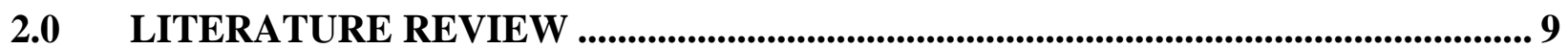

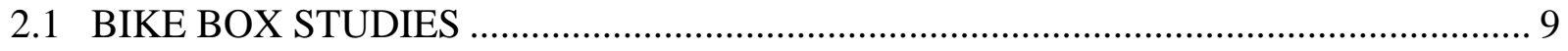

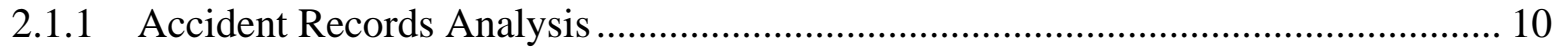

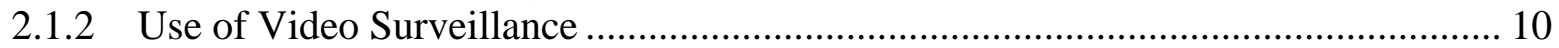

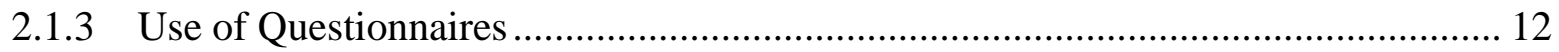

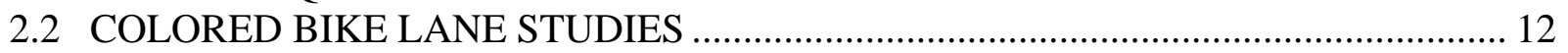

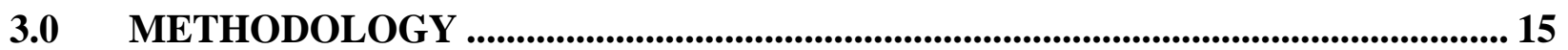

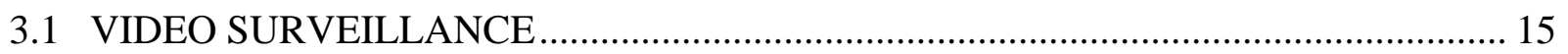

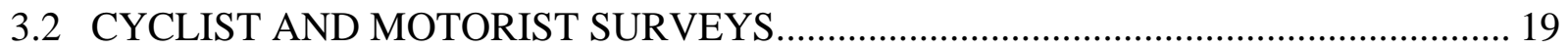

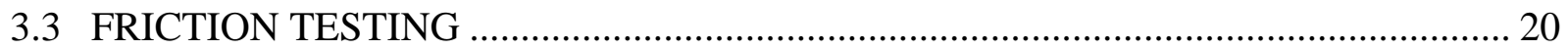

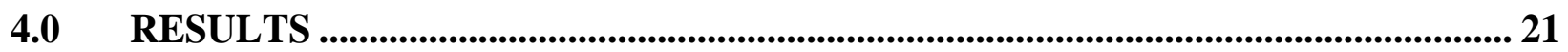

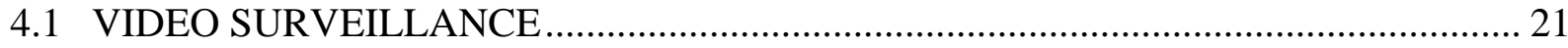

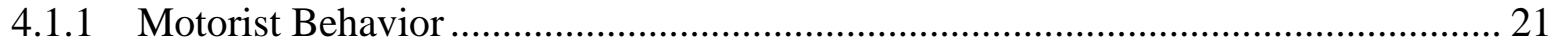

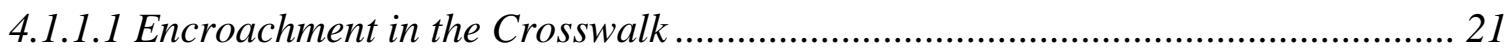

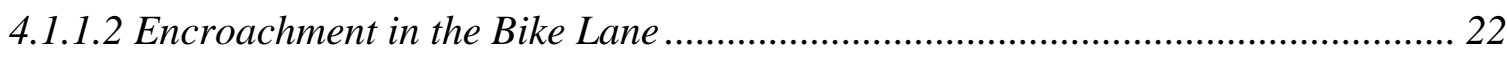

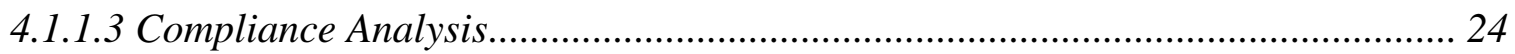

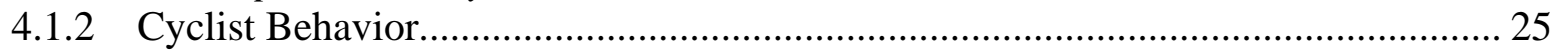

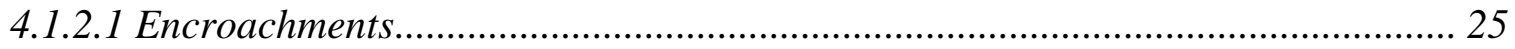

4.1.2.2 Cyclists Position in the Bike Box ………………........................................ 25

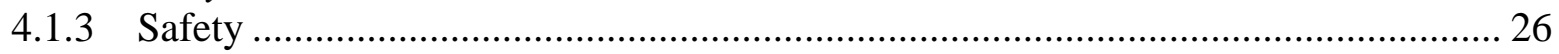

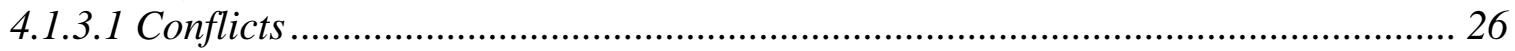

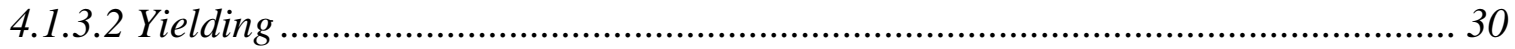

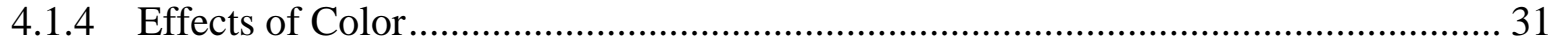

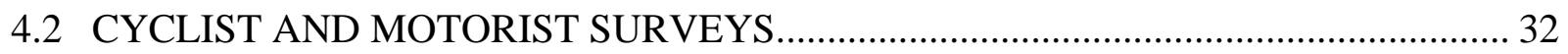

4.2.1 Did road users understand the markings? ............................................................ 32

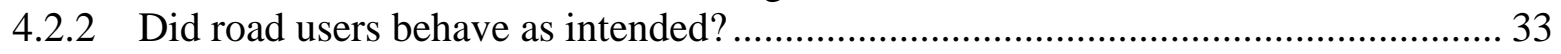

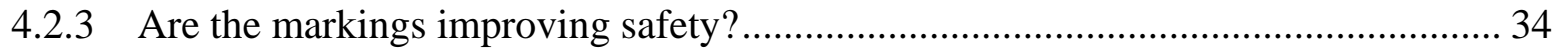

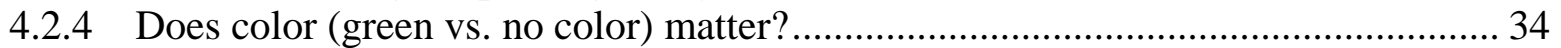

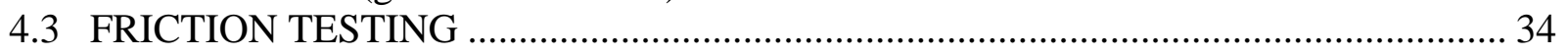

5.0 CONCLUSIONS …............................................................................................................ 37

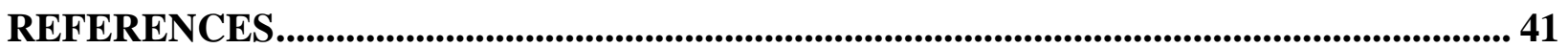

\section{APPENDICES}

APPENDIX A: INTERSECTION PLANS AND PHOTOGRAPHS

APPENDIX B: CYCLIST AND MOTORIST SURVEYS

APPENDIX C: SURVEY RESPONSES 


\section{LIST OF TABLES}

Table 1 Summary of Video Observation Data...................................................................... 17

Table 2 Motor Vehicle Encroachment in Crosswalk ................................................................ 22

Table 3 Motor Vehicle Encroachment in Bike Lane ............................................................. 23

Table 4 Motor Vehicle Encroachment in Crosswalk (Before) and Bike Box (After) ................. 24

Table 5 Motor Vehicle Encroachment in Bike Box............................................................... 24

Table 6 Cyclist Encroachment in Crosswalk ..................................................................... 25

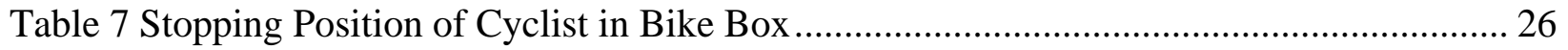

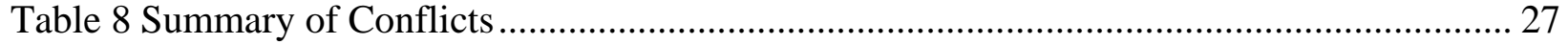

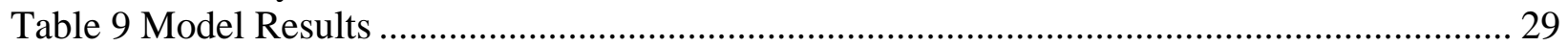

Table 10 Summary of Yielding Behavior, Before (B) to After (A) Treatment .......................... 31

Table 11 Surveyed Motorists' Understanding of Bike Boxes ............................................. 33

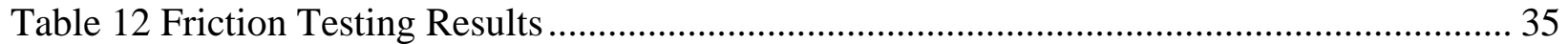

\section{LIST OF FIGURES}

Figure 1 Photo of green bike box at signalized intersection in Portland, OR............................ 7

Figure 2 Photo of uncolored bike box at signalized intersection in Portland, OR...................... 7

Figure 3 Average monthly high temperature and precipitation, January 2008-December 2009,

Portland OR. 15

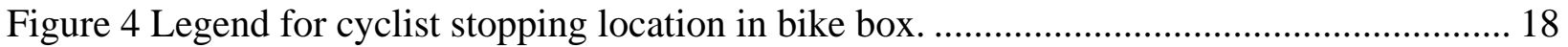

Figure 5 Before and After Hourly Conflict Counts by Intersection ....................................... 28

Figure 6 Isocontour plot of the difference between the estimated conflicts before and after per hour 


\section{EXECUTIVE SUMMARY}

Many U.S. cities, including Portland, OR, are increasing their efforts to get more people bicycling and to improve the safety of cyclists on the road. Collisions between cyclists and motorists are the cause of most bicycle fatalities. A common bicycle-motorist crash pattern is the "right-hook," where right-turning motorists collide with through or stopped bicycles. One possible treatment to ameliorate these crashes and conflicts is the installation of a "bike box." Used at signalized intersections, the bike box places bicyclists in front of motor vehicles, with the aim of increasing their visibility and reducing conflict.

In 2008, the City of Portland completed the first large-scale installation of this treatment in the United States by installing 12 bike boxes throughout the central core. The typical installation consists of an advanced stop line, green textured thermoplastic marking with a bicycle stencil, intersection striping, and regulatory signage (including no-turn-on-red). Three installations omitted the green textured thermoplastic so that a comparison could be made. This research project aims to build knowledge about how this marking is working in the context of an American city. This project sought to assess road users' understanding and compliance with the new markings, effects on safety, and whether the green thermoplastic treatment (versus no color) improved outcomes.

Research methods included the analysis of before-and-after video data and surveys of motorists and cyclists. The analysis was drawn from 918 hours of video, from which the researchers coded 83 hours for usage and compliance (5,315 cyclists), and 139 hours for bicyclist-motorist conflicts (7,454 cyclists). Researchers also analyzed 17 hours of video for motorist yielding behaviors and recorded the behaviors of 1,141 vehicles, of which 135 had interactions with bicyclists necessitating yielding behaviors. Researchers surveyed 468 cyclists who were intercepted as they approached or passed through bike boxes. In addition, 721 motorists who were recruited via email completed a survey. Both surveys asked questions assessing whether respondents understood the markings and their reactions to the markings.

The key findings are as follows:

\section{Do cyclists and motorists understand and comply with the new bike box markings? Most motorists and cyclists appear to understand and comply with the markings.}

- Video analysis found that $77 \%$ of motorists stopped at the appropriate position before the installation (at the stop bar prior to the pedestrian crosswalk), while $73 \%$ stopped at the appropriate position after the installation (at the stop bar prior to the bike box). On a variety of measures in the survey, motorists indicated an understanding of the bike boxes of $86 \%$ or better.

- With the bike box in place, $73 \%$ of the stopping cyclists correctly stopped ahead of the motor vehicle stop line, though only 5\% stopped in the area of the box directly in front of where a motor vehicle would stop. However, more cyclists (38\%) stopped in the bike 
box directly in front of where a motor vehicle would stop when other cyclists were already waiting in the box area.

- Cyclist encroachment in the crosswalk decreased significantly after the installation of the bike boxes, dropping from $41 \%$ to $25 \%$ of cyclists arriving on a red signal.

\section{Do the bike boxes improve safety? After controlling for volumes, the number of conflicts decreased and yielding behavior increased. In addition, user perceptions of safety improved.}

- Conflicts: Overall, the number of observed conflicts decreased from 29 to 20 while the total number of cyclists increased $94 \%$ and motor vehicle right-turn volumes increased by $15 \%$. Controlling for differences in volumes of bicycles and right-turning vehicles, fewer bicycle-motor vehicle conflicts are expected for an intersection with a bike box.

- Yielding: Our analysis of the three additional intersections for yielding behavior found an increase in the key behavior of right-turning cars yielding to cyclists at the treatment locations and a decrease at the control location. The increase is partially driven by additional interactions as a result of increased volumes; however, the increase in yielding is proportionally more than the volume increase.

- Perception of Safety: The surveys found that both motorists and cyclists perceived the intersections to be safer after the installation of the bike boxes. In particular, $42 \%$ of motorists who are not cyclists felt driving through the intersections was safer with the bike boxes (compared to $14 \%$ who felt it was more dangerous). Moreover, $77 \%$ of cyclists felt bicycling through the intersections was safer with the bike boxes (compared to $2 \%$ who felt it was more dangerous).

Does the green color make a difference? The observational data did not detect significant differences between the green and no-color boxes, though the vast majority of surveyed motorists preferred the green boxes.

- Although the timing of the bike box installations and the selection of intersections to receive color versus no color made a comparison difficult, some observations can be made about the observed effects of color on motorist and cyclist behavior. Motor vehicle encroachment in the bike lane prior to arriving at the intersection decreased for color locations, but not no-color locations. The color locations appear to encourage cyclists to stop ahead of the motor vehicle stop line. No significant difference in the frequency of conflicts was observed between color and no-color locations. In the survey, nearly $90 \%$ of motorists preferred the green bike box to the no-color bike box.

\section{Study Limitations}

It is not clear how transferable the results are to other cities. Rates of bicycling in Portland are among the highest of any U.S. city, particularly in the core downtown area where the boxes were installed. The city has adopted many policies and programs, installed other infrastructure aimed at increasing cycling, and the city's residents are generally favorable towards cycling. In addition, awareness of safety issues is high; $95 \%$ of the motorists surveyed remembered reading or hearing about a right-hook crash involving a cyclist. This context may have resulted in more positive results than other cities might experience. The small sample size of the non-color 
locations makes conclusions about the effects of color less clear. The lack of crash data, though typical of this type of study, also limits the findings; we will need to revisit this evaluation over time when actual crash data are available. The negative-binomial (NB) safety comparison model may not be reliable at the upper range of the volumes because of the lack of data. Therefore, we do not maintain that the results are conclusive. These limitations point to the need for additional monitoring and evaluation over longer time periods and additional contexts. 


\subsection{INTRODUCTION}

\subsection{THE PROBLEM}

The U.S. Department of Transportation (DOT) set two goals in its 1994 National Bicycling and Walking Study: To double the number of total trips made by bicycling and walking in the United States from $7.9 \%$ to $15.8 \%$ of all travel trips, and to reduce by $10 \%$ the number of bicyclists and pedestrians killed or injured in traffic crashes. These goals were adopted by Congress (NCHRP 2008). More recently, the Secretary of Transportation, Ray LaHood, issued a new policy statement on bicycle and pedestrian accommodation:

The DOT policy is to incorporate safe and convenient walking and bicycling facilities into transportation projects. Every transportation agency, including DOT, has the responsibility to improve conditions and opportunities for walking and bicycling and to integrate walking and bicycling into their transportation systems. Because of the numerous individual and community benefits that walking and bicycling provide — including health, safety, environmental, transportation, and quality of life - transportation agencies are encouraged to go beyond minimum standards to provide safe and convenient facilities for these modes. (U.S. Department of Transportation 2010)

However, in the most recent years for which data is available, bicycling as a percentage of all trips has barely increased, while bicycle injuries and fatalities have increased (NCHRP 2008). Crashes with motor vehicles account for $90 \%$ of bicycle fatalities, yet only $11 \%$ of all bicycle crashes (2002 Data: City of Portland, 2004). Thus, they must be a target in the effort to reduce bicycle fatalities.

The American Community Survey, an annual survey conducted by the U.S. Census Bureau, has recorded a tripling in the share of the City of Portland's workers who regularly commute by bicycle between 1996 (1.8\%) and 2008 (6.0\%). Despite this increase in bicycling activity, a recent survey found that a majority of residents limit their bicycling due to traffic safety concerns (City of Portland, 2007). Analyses of motor vehicle and police reported crash data reveal that nearly $68 \%$ of bicycle crashes in Portland occur at intersections (City of Portland, 2004), which are consistent with national trends (Hunter et al., 1996). Hunter et al. also found that $12.2 \%$ of crashes involving bicyclists and motor vehicles occurred when a motorist turned or merged into a cyclist's path. Of these intersection crash types, a common crash pattern is the "right-hook," where right-turning motorists collide with through or stopped bicycles.

This conflict occurs whether or not a bicycle lane is present; however, the presence of a bicycle lane adds additional complexity to safe design and operation of the intersection. Where space allows and right-turn movements are heavy, the AASHTO guidance suggests transitioning the bicycle lane from the curb to the left of the right-turn lane. This has a number of advantages. In dense urban environments, however, the provision of right-turn-only lanes is often not feasible and the bicycle lane must remain to the right of the right-turn lane. This location violates driver (and cyclist) expectancies by placing through bicycles to the right of potentially conflicting motor vehicles. When stopped and waiting to turn right or when attempting to turn right while in 
motion, it is much more likely that a driver will fail to observe a bicycle to the right. In high driver-demand situations (such as urban areas), this possibility only increases. In its 2008 Guide for Reducing Collisions Involving Bicycles, the National Cooperative Highway Research Program identifies improving pavement markings at intersections as an important moderate cost and quickly implementable strategy to address the dangers of bicycling (NCHRP 2008).

\subsection{BIKE BOXES AS A POSSIBLE SOLUTION}

Bike boxes, commonly known outside the United States as advanced stop boxes (ASBs), usually incorporating advanced stop lines (ASLs) for motor vehicles, have been in use for over 20 years in parts of Northern Europe. The Netherlands, Germany, Denmark and the United Kingdom have all utilized variations on the treatment. More recently, the treatment has been adapted for use in a number of other countries including Taiwan, Australia, New Zealand, France, Canada and the United States. This treatment is hypothesized to reduce conflicts between motor vehicles and cyclists and help motorists identify areas of potential conflict. An additional desired secondary outcome would be to encourage more bicycling by enhancing the perception of safety and priority at an intersection. By design, bike boxes place cyclists at the front of the queue at a red signal, which should increase their visibility. Some treatments are designed to assist cyclists in turning across oncoming traffic (i.e., turning left in the United States, or right in the United Kingdom). Others have been designed to facilitate cyclists when the bicycle lane crosses from one side of the road to another (Hunter, 2000). Perhaps the most common application of the bike box is to place cyclists in front of right-turning vehicles, proactively preventing collisions where the motor vehicle turns right in front of a through cyclist in the adjacent bicycle lane - the "righthook."

Bike box treatments can have a number of variations. Bike boxes designed to help cyclists turn across traffic or to navigate a bicycle lane switch from one side of the road to another are more likely to extend across all lanes of traffic. Bike boxes designed to assist cyclists proceeding straight through the intersection are more likely to be limited to a one-lane width. Demarcating the box with colored surfacing, to increase contrast, is a common strategy. Known applications of color include green (e.g., Portland and Tucson, AZ), red (e.g., Vancouver, B.C, and Christchurch, NZ), or blue (Victoria, B.C.). A common practice in the Netherlands is to provide a separate cyclist-specific signal, giving cyclists a brief head start; however, this is rare in the United States. Because a bike box places bicycles in front of motorist traffic, they can impede motorists from making right turns at red signals. For this reason, the bike boxes are sometimes paired with "no right turn on red" signs.

To partially address right-hook conflicts at intersections with bicycle lanes, the City of Portland installed 12 bike boxes at signalized intersections in 2008. Figure 1 shows the typical installation in Portland, which consisted of an advanced stop line, green textured thermoplastic marking with a bicycle stencil, intersection striping, and regulatory signage including no-turn-on-red (generally, right turns are permitted on red lights in Portland). In addition, the words "WAIT HERE" are stenciled just before the stop line and colored bicycle lane markings were added in the intersection. Three intersections did not include the green thermoplastic marking, one of which is shown in Figure 2. All of the intersections were in the core downtown area or on a major street leading into or out of the core. Prior to the installation of treatments, the City of Portland engaged in a public education campaign that included posters and billboards with a 
marketing slogan of "Get Behind It. The Bike Box: Portland's new green space." The posters were affixed near the bike box locations facing approaching traffic. The city also distributed brochures explaining the purpose and intended use of the boxes. The Portland Police Bureau conducted a short enforcement campaign and issued citations and warnings.

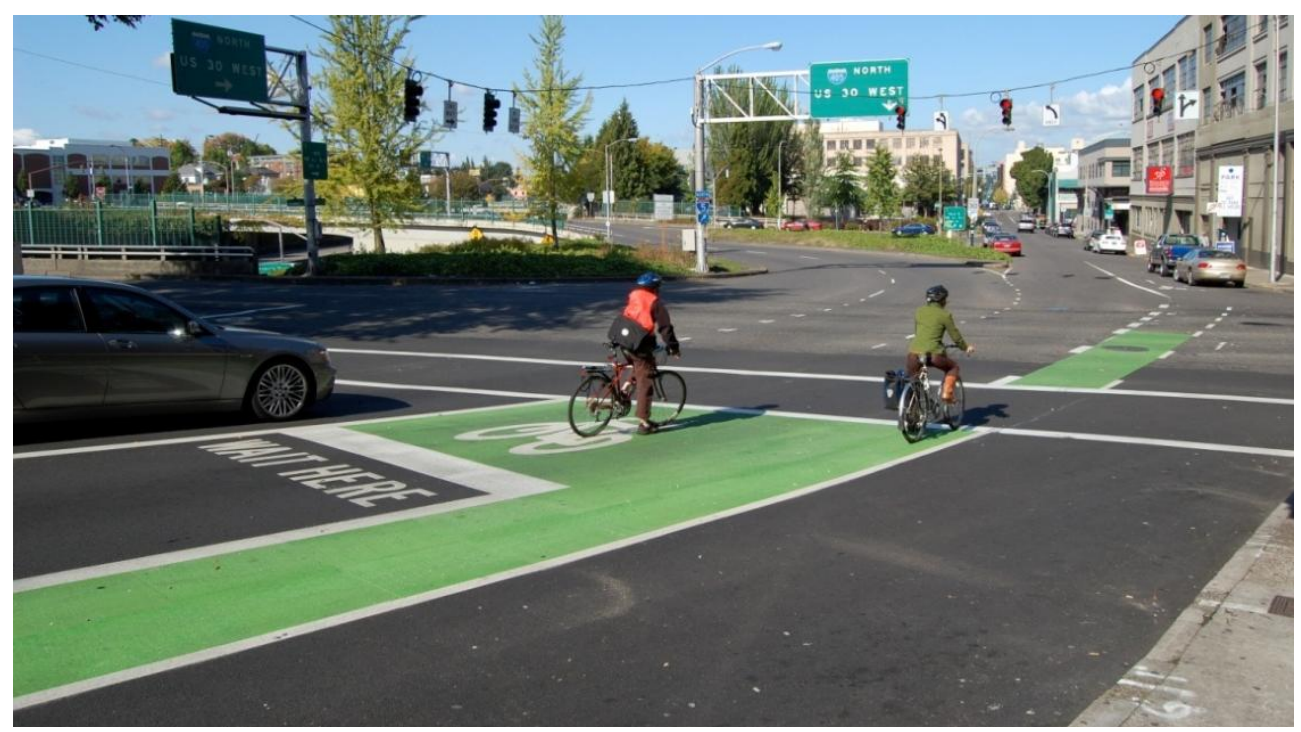

Figure 1 Photo of green bike box at signalized intersection in Portland, OR.

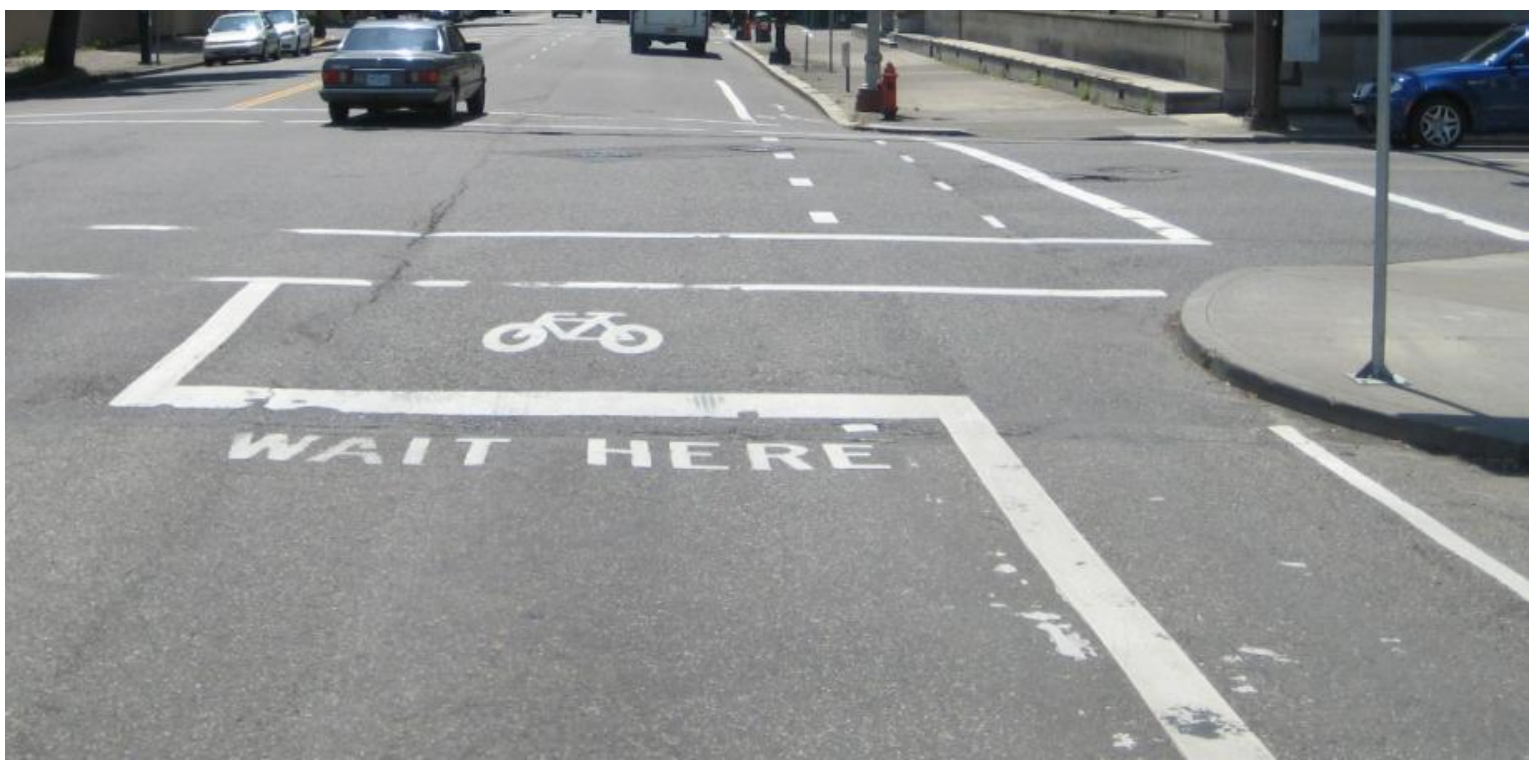

Figure 2 Photo of uncolored bike box at signalized intersection in Portland, OR

Since the City of Portland installed bike boxes, a number of other cities have followed with similar installations. These include Phoenix and Tucson, AZ; Long Beach, West Hollywood and San Francisco, CA; Boston and Cambridge, MA; Minneapolis, MN; Albuquerque, NM; New York, NY; Columbus, OH; Eugene, OR; Austin, TX; Alexandria, VA; Madison, WI; and Washington, D.C. 


\subsection{RESEARCH QUESTIONS}

This study is an observational before-and-after study of the effectiveness of the installed experimental traffic control devices and responses of all system users impacted by the installation of the bicycle boxes using two primary research methods: (1) before-and-after video surveillance of the intersections where bike boxes were to be installed and appropriate control intersections; and (2) surveys of cyclists and drivers. This before-and-after study presents findings from 10 of the intersections with bike boxes ("treatment") and two "control" intersections. The research focuses on how motorists and cyclists understand and use the bike boxes, and the impact of the bike boxes on safety. In particular, the following questions are addressed:

- Do road users (motorists and cyclists) understand the markings?

- Do road users behave as intended?

- Are the markings improving safety?

- Does color (green vs. no color) matter?

- Does the green thermoplastic alter road friction? 


\subsection{LITERATURE REVIEW}

\section{$2.1 \quad$ BIKE BOX STUDIES}

This review focuses on the methods and findings from six previous studies that have examined the effects of bike boxes:

- Wall et al. (2003) considered the capacity implications of four bike box installations in the UK and included a useful overview of previous research into ASLs in the Netherlands and UK. All four bike boxes had nearside feeder lanes, while one also had a central feeder (between motorist lanes). The number of lanes on approach varies from one to three, and in each case the bike box extends across all lanes. Satellite imagery shows the boxes received a colored treatment.

- Newman (2002) examined the effect of bike boxes and advanced cycle-lane installations on vehicles and cyclists at seven intersections in Christchurch, NZ. The study covered one type of bike box layout at three intersections: the layout includes a nearside feeder lane and extends across both approaching lanes. The boxes are designed to assist cyclist in moving straight through the intersection, but offer assistance for cyclists to maneuver into a right-turn lane at a red signal. None of the boxes used in the study had received colored treatment.

- Hunter (2000) evaluated a bike box installation in Eugene, OR, and is the only evaluation of a bike box in the United States that we identified. This bike box aimed to connect a left-side bicycle lane to a right-side bicycle lane at the far side of an intersection. The box extends across the two straight-ahead lanes of the three-lane one-way street - the box does not extend across the right-turn lane. The box did not receive colored treatment.

- Transport for London (TfL) commissioned three studies on ASLs, which were published in 2005. Allen et al. (2005) assessed cyclist and motorist behavior at 12 intersections after the installation of bike boxes, and at two control intersections. An array of sites with and without feeder lanes, and with from one to three approaching lanes, were chosen. Each box extended the width of all approaching lanes. The boxes were colored grey or green. Atkins (2005) evaluated three variations of bike box layouts at 10 intersections and two control sites in South London. Five of the bike boxes were partial width, covering one approaching lane, while five covered all approaching lanes. Five had feeder lanes while five used other measures, such as virtual cycle lanes or stubs (both of which are carved out of normal-width motorist lanes). Eight of the 10 boxes were colored green. Rodgers (2005) is a before-and-after study of the effect of bike boxes installed along two major cycling routes in South London. The boxes are either partial or full width, and most are treated with green coloring.

The review is supplemented with a handful of studies on colored bike lanes. 


\subsubsection{Accident Records Analysis}

In theory, bicycle crash data offer concrete evidence of changes in intersection safety. However, in practice drawing valid conclusions from available crash data has proven very difficult. Three of the six bike box studies analyzed bicycle and motor vehicle accident records (Allen et al., 2005; Newman, 2002; Rodgers, 2005). However, none of the studies found that there was an adequate amount of crash data to draw firm conclusions. Newman (2002) found an overall trend toward accident reduction after installation, while Allen et al. (2005) found some sites with increased casualties and others with decreased casualties. Neither study had statistically significant findings. Rodgers (2005) analyzed accident records for the period prior to the bike box installation, but concluded there was not enough data in the short period of time after the installation to merit including after-installation data. Atkins (2005) utilized accident records to identify which intersections were appropriate for study, but did not include any analysis of accident data in the study.

The difficulty presented by incomplete accident data in assessing intersection safety is not unique to these bike box studies. A meta-analysis of accident reporting across 13 countries, including the United States, found that single-vehicle bicycle accident reporting was the lowest of all categories - at less than 10\% (Elvik and Mysen, 1999). Another study found that fewer than $10 \%$ of emergency-room cases that resulted from bicycle accidents were duplicated in state accident files (Stutts and Hunter, 1999).

\subsubsection{Use of Video Surveillance}

Because of the difficulty in utilizing accident data, most prior studies of bike boxes have relied on a combination of video surveillance and user questionnaires. Each of the six studies used video surveillance to assess bike box usage, cyclist and motorist behaviors and interactions at the altered intersections. Hours of video footage taken ranged from four hours per site (Wall et al., 2003) to more than 24 hours per site (Atkins, 2005). Each study shot video of at least one rushhour period, and two studies shot footage from the beginning of the morning rush (7 a.m.) through 6 p.m. (Allen et al., 2005) or 7 p.m. (Atkins, 2005).

Five of the six studies examined whether cyclists were utilizing bike boxes appropriately. Newman (2002) found that practically all stopping cyclists used the bike box as intended. Other studies found far more modest results: Hunter (2000) found that $11 \%$ used the box as intended (16\% used it in some way); Atkins (2005) found that $25 \%$ of cyclists arriving at red signals waited in the box; Wall et al. (2003) found that $23 \%$ of cyclists waited in the box; and Allen et al. (2005) found that $38 \%$ of cyclists waited in the box (and $78 \%$ of waiting cyclists positioned themselves in front of automobile traffic, compared with 54\% at control sites). Two of the studies found that inappropriate lane use or crossing of lanes at intersections significantly decreased (Hunter, 2000 and Newman, 2002). One study found that the percentage of cyclists positioning themselves ahead of traffic at red signals was significantly higher (Allen et al., 2005).

The variations in these findings derive from considerable variation in definitions of appropriate use: 
- Allen et al. (2005) examined cyclist usage of bike boxes by considering, of those cyclists waiting at a red light, what percentage waited inside the box, as opposed to in the pedestrian crosswalk, beyond the box, or elsewhere. The study's data also show that $29 \%$ percent of cyclists arriving at a red signal violated the red light.

- Atkins (2005) examined those cyclists that arrived at an intersection during a red signal; if we were to extract only those that waited at the red signal (i.e., remove those that violate the red signal - which averaged $39 \%$ of cyclists arriving during the red signal), then $39 \%$ of cyclists stopping at the red light stopped in the bike box.

- Hunter (2000) employed a very specific definition of appropriate use of the box (to move cyclists from a left side bicycle lane (BL), across three lanes of traffic, to a right side BL), which contributed to the lower percentage of cyclists using the box as intended. The study defined appropriate use, or "intended" use, as approaching from the left-side BL, moving into the box in front of traffic on a red signal, and then proceeding into the rightside BL on the green signal. This study also does not distinguish between cyclists arriving at green signals and those arriving at red signals.

- Newman (2002) examined how many cyclists approaching the intersection at a red light used the reservoir, and stopped within the box. Sixty-one cyclists used the reservoir correctly, while five stopped elsewhere (in the cycle lane, at the vehicle limit line or behind traffic) and seven did not stop at the red light.

- Wall et al. (2003) recorded whether cyclists waited inside the bike box, in front of the bike box, or did not queue. The study does not explain where those that did not queue waited.

Four of the studies (Allen et al., 2005; Atkins, 2005; Hunter, 2000; Newman, 2002) examined video recordings to determine if motorists inappropriately encroached into bike boxes during the red-signal phase. Each study found some degree of motorist encroachment into the bike boxes, although definitions of encroachment varied. Hunter defined encroachment as when up to a quarter of the motor vehicle is the bike box during a red-signal phase, while others defined it as when the motorist drives over the stop line and stops in the bike box (Newman, 2002) or when the motor vehicle's front wheels are stopped in the bike box (Wall et al., 2003). Three of the studies employed a tiered encroachment definition system depending on the percentage of the vehicle in the bike box (Allen et al., 2005; Hunter, 2000) or the percentage of the bike box that is coved by the vehicle (Atkins, 2005). Definitions also differed on how often encroachment occurred, with some studies providing the percent of traffic cycles in which the front vehicle encroached on the bike box (Atkins, 2005; Hunter, 2000; Newman, 2002; Wall et al., 2003), or the percentage of cyclists that encountered some level of encroachment (Allen et al., 2005). Allen et al. found that $36 \%$ of the cyclists experienced some level of encroachment. Hunter found that encroachment was more severe during heavy traffic flows. And Atkins determined that high levels of encroachment were preventing cyclists from using bike box reservoirs.

Four of the studies examined video recordings to assess the level of conflict between motorists and cyclists. Wall et al. (2003) defined conflict as interactions that could potentially lead to a collision if evasive action was not taken by the cyclist or motorist. Three of the studies rated the conflict on a scale of severity, including minor conflict and major conflict, with some variation on definitions or further breakdowns (Allen et al., 2005; Atkins, 2005; Hunter, 2000). One study found no instances of conflict (Wall et al., 2003), while two studies found that the incidence of 
conflict was too low to conduct significant analysis on the impact of the bike box installation (Allen et al., 2005; Atkins, 2005). Hunter (2000) found the level of conflict low both before and after bike box installation, with no significant difference.

\subsubsection{Use of Questionnaires}

Four of the six bike box evaluations included surveys of cyclists (Hunter, 2000; Newman, 2002; Rodgers, 2005; Wall et al., 2003). Three studies utilized intercept surveys, while the fourth (Newman, 2002) solicited responses via email and by handing out surveys for cyclists to mail back. Rodgers (2005) was the only study that included a component of the survey from before installation. The number of people surveyed (after installation) ranged from 45 to 80 (Hunter (2000) did not state the number of surveys conducted).

Three of the studies identified findings related to cyclists' sense of safety. In one study, $70 \%$ of cyclists continuing straight through an intersection felt safer with the bike box treatment than without (Newman, 2002). In another, $51 \%$ of those surveyed felt safer after treatment, while $45 \%$ felt no difference and $86 \%$ felt the bike boxes were better than no bicycle facility at all (Rodgers, 2005). In a third study, $71 \%$ of those surveyed felt the treatment made the intersection either a lot or a little safer, and $74 \%$ felt the changes made the intersection easier for cyclists (Wall et al., 2003).

Three of the studies asked questions aimed at identifying the cyclists' understanding of the appropriate way to use the bike box; however, varying wording makes cross-study comparisons difficult. Hunter (2000) found that 59\% of respondents were unsure of the purpose of the bike box. Newman (2002) left the question open ended, and most respondents demonstrated an understanding the purpose of the bike boxes in their responses. Wall et al. (2003) found that 89\% of respondents knew where to wait at an intersection during a red signal.

Only one of the bike box studies surveyed motorists, though the sample was small $(n=74)$ (Newman, 2002). In an open-ended question about the purpose of the bike box, $57 \%$ provided an answer that was consistent with the purpose, including a waiting place for cyclists, making cyclists more visible, improving safety, and stopping motor vehicles further away. Only $15 \%$ of the drivers thought that the boxes made the intersection safer for cyclists, though $62 \%$ did not know or answer the question. A larger share thought that the boxes made the intersections more dangerous for drivers (28\%) than safer for drivers (19\%).

\subsection{COLORED BIKE LANE STUDIES}

Several studies have evaluated the impact of colored pavement markings, including blue, green and red markings, designed to articulate potential conflict areas between bicycles and automobiles. Five studies were identified that examine the effect of colored bike lanes extending across areas of potential conflict with automobiles, including areas where motorists may be making right turns. Hunter et al. (2000) used before-and-after video, along with cyclist and motorist questionnaires, to evaluate 10 bicycle-automobile conflict areas in Portland that were treated with blue pavement markings. Garder et al. (1998) is a before-and-after study of four cycle track intersection crossings in Gothenburg, Sweden, that were elevated and painted red. 
The study utilized surveys of bicyclists and selected experts, accident analysis, and video analysis. Sadek et al. (2007) evaluated the effectiveness of two green bicycle-lane crossing treatments and two control crossings in South Burlington, VT, using visual and video surveillance, along with surveys for bicyclists and motorists. Jensen (2008) conducted a review of before-and-after accident data at 65 signalized intersections with blue bicycle lane crossing treatments. Koorey and Mangundu (2010) evaluated the effect of colored versus uncolored surfacing on motorist encroachment in ASLs and ASBs in Christchurch, NZ. They find that motorist were much less likely to encroach on colored surfaces, particularly in the case of turning vehicles and ASLs.

Two of the studies found increases in cyclist safety (Hunter et al., 2000 and Jensen, 2008), while a third suggested that the colored lanes were believed to contribute to an increase in safety (Garder et al., 1998). The fourth study did not identify a change in safety. Two studies noted an increase in yielding behavior among motorists (Hunter et al., 2000; Jensen, 2008), while a third noted that motorists' speeds as they crossed the bike lane were significantly slower than before the treatment (Garder et al., 1998). One study did not find any significant increase in motorist yielding behavior (Sadek et al., 2007). Hunter et al. (2000) also identified a decrease in the number of cyclists turning their heads to look for oncoming motorists and using hand signals before turning using the colored lanes. Garder et al. (1998) also found that the new facility encouraged up to $50 \%$ more cyclists. 


\subsection{METHODOLOGY}

\subsection{VIDEO SURVEILLANCE}

Video cameras installed by the City of Portland on nearby signal or utility poles captured a total of approximately 48 hours of video at each of the selected bike box and control intersections before and after installation. In most cases the cameras were positioned facing approaching traffic as it moved through the bike box (or control) area. Before video was collected January through March 2008; after video was collected April through June 2009. Generally, the collection period was from 7 a.m. to 7 p.m. for two consecutive midweek days (both before and after installation).

Average high temperature and monthly precipitation recorded by the National Oceanic and Atmospheric Administration for this time period is shown in Figure 3. The data collection periods are shown by the horizontal boxes. Average weather patterns are different between the time periods, especially comparing the beginning of the before and the end of the after periods. Because of the short time between the decision to install the boxes and installation, which began in April 2008, it was not possible to collect before data during better and more comparable weather and lighting conditions.

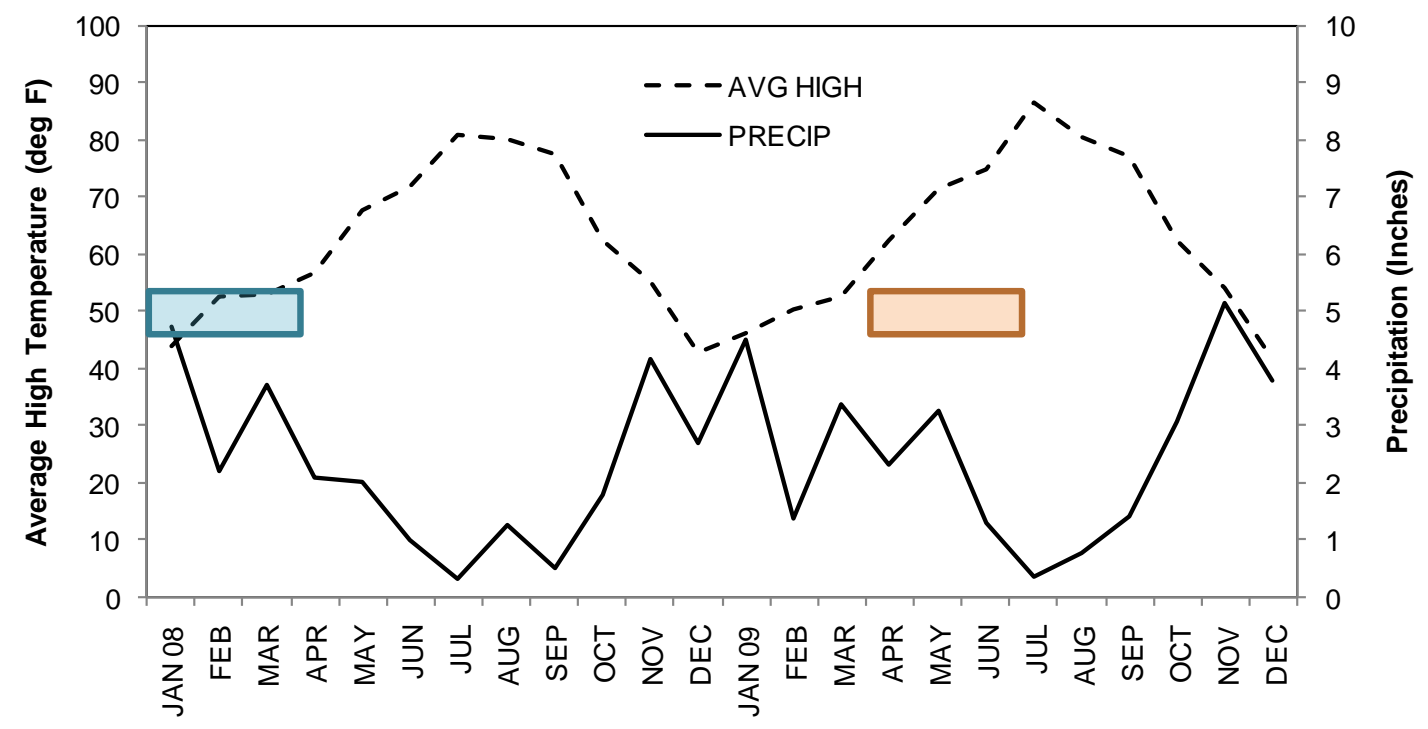

Figure 3 Average monthly high temperature and precipitation, January 2008-December 2009, Portland OR.

The before video was condensed-frame VHS, which was digitized for analysis, while the after video was digital. Due to video errors and construction issues, before-and-after video was available for 10 bike boxes (seven green, and three uncolored) and two control locations. Three research assistants viewed and coded the video.

For each location and time period (before and after), data were collected from the video for two peak period hours and one off-peak hour. Each intersection was designated as either an AM or 
PM peak intersection, depending on observed traffic patterns. For each intersection, for each period (before and after), two hours of peak video were selected by taking one peak hour from two consecutive days. The AM peak hour reviewed was 8 to 9 a.m., and the PM peak hour was 4:45 to 5:45 p.m. One non-peak hour was also selected for each intersection, for each period: 12 to $1 \mathrm{p} . \mathrm{m}$. A total of three hours of pre-treatment video and three hours of post-treatment video were selected for review for each intersection. There were several exceptions to this program. Review of Southwest Broadway at Southwest Hoyt Street for the before period was limited to two hours (one peak hour and one non-peak hour) due to a video error resulting in a second peak period not being recorded. Before video of the Southeast Hawthorne Boulevard at Southeast $7^{\text {th }}$ Avenue intersection used a PM peak of 4 to $5 \mathrm{p} . \mathrm{m}$. because of short daylight hours at the time the video was recorded (January). Finally, the hour of non-peak video at Hawthorne at $7^{\text {th }}$ for the before period was shifted back 10 minutes (to 12:10 to 1:10 p.m.) because a parked truck obscured the view of the intersection from noon until 12:10 p.m.

The research assistants recorded information on each cyclist proceeding through the intersection in the direction of the bike box. For each cyclist, reviewers marked the time of arrival at the intersection, the approach lane (e.g., bike lane or traffic lane), signal phase at arrival (red or green), stopping location, red-light violations, position relative to the nearest car, whether any conflict occurred, helmet or light usage (when possible), and the cyclist's path through the intersection (straight, left, or right). Video quality and camera positioning made some determinations difficult or impossible in some instances, particularly regarding red-light violations, helmet usage and light usage.

Reviewers also recorded the total number of motorists in the lane adjacent to the bicycle lane and the total number of cars turning right. Reviewers noted each motorist at the front of the queue in the right lane (adjacent to the bicycle lane) during red lights, and noted if the motorist stopping position encroached on the bike box or pedestrian crosswalk. The number and degree of encroachments on the bike lane, either during a red light or while proceeding through the intersection on a green light, were also recorded. Additionally, reviewers counted the number of pedestrians using the crosswalk immediately in front of the bike box location.

The three-hour volume of motor vehicles at the intersections ranges from 140 to 1,655, and the three-hour volume of cyclists ranges from 13 to 640. A summary of these data is presented in Table 1. 
Table 1 Summary of Video Observation Data

\begin{tabular}{|c|c|c|c|c|c|c|c|c|c|c|c|}
\hline \multirow{2}{*}{$\begin{array}{c}\text { Intersection } \\
\text { Name }\end{array}$} & \multirow{2}{*}{$\begin{array}{l}\text { Approach } \\
\text { with Bike } \\
\text { Box }\end{array}$} & \multicolumn{2}{|c|}{ Total Cyclists } & \multicolumn{2}{|c|}{$\begin{array}{c}\text { Cyclists } \\
\text { Arriving on } \\
\text { Red } \\
\end{array}$} & \multicolumn{2}{|c|}{$\begin{array}{l}\text { Total Vehicles } \\
\text { in Right Lane }\end{array}$} & \multicolumn{2}{|c|}{$\begin{array}{c}\text { Vehicles } \\
\text { Turning Right } \\
\end{array}$} & \multicolumn{2}{|c|}{$\begin{array}{c}\text { Vehicles } \\
\text { Arriving On } \\
\text { Red } \\
\end{array}$} \\
\hline & & Before & After & Before & After & Before & After & Before & After & Before & After \\
\hline \multicolumn{12}{|c|}{ Color } \\
\hline $\begin{array}{l}\text { NW Everett \& } \\
16^{\text {th }}\end{array}$ & $\begin{array}{r}2 \text { lane, } \\
\text { one-way }\end{array}$ & 58 & 125 & 7 & 19 & 1,447 & 1,307 & 909 & 959 & 149 & 144 \\
\hline $\begin{array}{l}\text { SE 11th \& } \\
\text { Hawthorne }\end{array}$ & $\begin{array}{r}3 \text { lane, } \\
\text { one-way }\end{array}$ & 369 & 511 & 142 & 184 & 1,150 & 1,034 & 231 & 206 & 148 & 132 \\
\hline $\begin{array}{l}\text { SE 7th \& } \\
\text { Hawthorne }\end{array}$ & $\begin{array}{r}3 \text { lane, } \\
\text { one-way }\end{array}$ & 296 & 640 & 29 & 71 & 873 & 780 & 114 & 125 & 148 & 116 \\
\hline $\begin{array}{l}\text { SW 3rd \& } \\
\text { Madison }\end{array}$ & $\begin{array}{l}2 \text { lane, } \\
\text { one-way }\end{array}$ & 314 & 611 & 84 & 167 & 744 & 918 & 101 & 117 & 171 & 163 \\
\hline $\begin{array}{l}\text { SW Broadway } \\
\& \text { 6th Ave }\end{array}$ & $\begin{array}{r}3 \text { lane, } \\
\text { two-way }\end{array}$ & 34 & 58 & 20 & 36 & 140 & 146 & 3 & 5 & 60 & 77 \\
\hline $\begin{array}{l}\text { SW Broadway } \\
\text { \& Taylor }\end{array}$ & $\begin{array}{r}3 \text { lane, } \\
\text { one-way }\end{array}$ & 170 & 216 & 19 & 13 & 774 & 864 & 516 & 566 & 148 & 148 \\
\hline \multirow[t]{2}{*}{$\begin{array}{l}\text { W Burnside \& } \\
\text { 14th Ave }\end{array}$} & $\begin{array}{r}3 \text { lane, } \\
\text { one-way }\end{array}$ & 42 & 59 & 27 & 33 & 644 & 671 & - & 181 & 153 & 136 \\
\hline & Subtotal & 1,283 & 2,220 & 328 & 523 & 5,772 & 5,720 & 1,874 & 2,159 & 977 & 916 \\
\hline \multicolumn{12}{|c|}{ No Color } \\
\hline $\begin{array}{l}\text { NW Broadway } \\
\& \text { Hoyt }\end{array}$ & $\begin{array}{l}2 \text { lane, } \\
\text { two-way }\end{array}$ & 155 & 607 & 55 & 114 & 778 & 1,085 & 204 & 243 & 122 & 149 \\
\hline $\begin{array}{l}\text { SW Terw. \& } \\
\text { Taylors Fy NB }\end{array}$ & $\begin{array}{l}2 \text { lane, } \\
\text { two-way }\end{array}$ & 13 & 11 & 8 & 4 & 1,193 & 1,655 & 110 & 134 & 142 & 103 \\
\hline \multirow[t]{2}{*}{$\begin{array}{l}\text { SW Terw. \& } \\
\text { Taylors Fy, SB }\end{array}$} & $\begin{array}{l}2 \text { lane, } \\
\text { two-way }\end{array}$ & 20 & 16 & 3 & 10 & 363 & 395 & 177 & 175 & 93 & 83 \\
\hline & Subtotal & 188 & 634 & 66 & 128 & 2,334 & 3,135 & 491 & 552 & 357 & 335 \\
\hline \multicolumn{12}{|c|}{ Control } \\
\hline $\begin{array}{l}\text { NE 16th \& } \\
\text { Weidler }\end{array}$ & $\begin{array}{r}2 \text { lane, } \\
\text { one-way }\end{array}$ & 82 & 55 & 11 & 9 & 1,875 & 1,878 & 134 & 145 & 134 & 108 \\
\hline \multirow[t]{2}{*}{$\begin{array}{l}\text { NE 7th \& } \\
\text { Weidler }\end{array}$} & $\begin{array}{l}3 \text { lane, } \\
\text { one-way }\end{array}$ & 92 & 69 & 9 & 13 & 1,904 & 1,929 & 227 & 218 & 136 & 131 \\
\hline & Subtotal & 174 & 124 & 20 & 22 & 3,779 & 3,807 & 361 & 363 & 270 & 239 \\
\hline
\end{tabular}

Notes:

Does not include data from 56 hours of additional video reviewed for conflicts

NW Broadway \& Hoyt and SW Broadway \& 6th Ave no bicycle lane downstream

SW Broadway \& 6th Ave no right turns allowed

Data were collected on motor vehicle and cyclist encroachment in the crosswalk, motor vehicle encroachment into the bike box and bike lane, and the location of stopped cyclists in the bike box. Motor vehicle encroachment in the crosswalk and bike box were coded as minor (up to $25 \%$ of the vehicle length across the line), moderate (up to $50 \%$ of the vehicle length across the line), 
or major (over $50 \%$ of the vehicle length across the line). Cyclist encroachment in the crosswalk was defined as when any part of the bicycle stopped in the marked crosswalk. Motor vehicle encroachment in the bike lane in the before situation was examined at three points: prior to the intersection, while making a right turn, and while stopped at the light. In the after situation, we coded whether the vehicle encroached in a "virtual" bike lane within the bike box - the area where the bike lane had been striped prior to the bike box installation. To better understand this encroachment measure, the reader is referred to Figure 4. Without the bike box, the bike-lane stripe would extend all the way to the crosswalk line (the left edge of rectangle B).

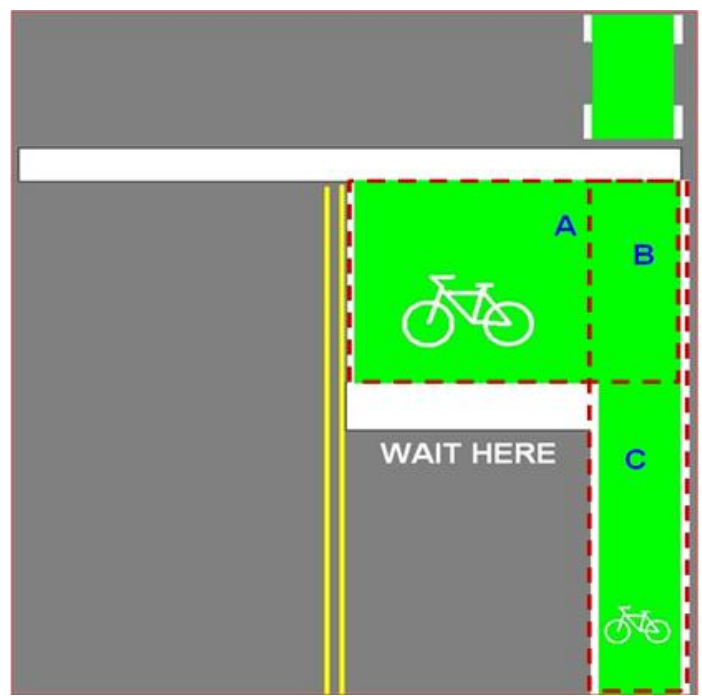

Figure 4 Legend for cyclist stopping location in bike box.

To capture how cyclists were using the box, we coded the location of each stopping cyclist in three general locations shown in Figure 4. We noted the presence of bicycles in location B so the decision to stop in the box (A) or prior to the box (C) could be separated by preference or volume. In all but two locations (Northwest Broadway at Hoyt and Southwest Broadway at $6^{\text {th }}$ Avenue), the bicycle lane continues downstream of the bike box. No left-turns would be legal (or practical) from any box. Thus, a cyclist's choice to use the box is one of preference. A fourth category ("D-other") includes cyclists stopping in the motor vehicle lane, the sidewalk, the crosswalk or other.

The change in safety performance was quantified by two surrogate measures: 1) change in the before-and-after bicycle-motor vehicle conflicts; and, 2) a change in yielding behaviors. Surrogate measures (rather than reported collision data) were used because, in general, motor vehicle-bicycle collisions are rare occurrences, and long time periods and a large number of treatment sites are needed for meaningful analysis with reported crash data. At the time of this paper's publication, there have been no known actual collisions at the treatment locations. During the review of the video data, all potential conflicts were flagged by the research assistants, who were instructed to liberally define these events as any motor vehicle-bicycle interaction that did not appear typical. To ensure repeatability, all three authors then reviewed each vehicle-bicycle interaction and rated them as major (near collision with emergency braking and/or change of direction), substantial (emergency braking and/or change of direction), minor 
(precautionary braking and/or change of direction), or no conflict. The severity of conflicts was measured by actions of either the motorist or the cyclist. A conflict was defined as series of events that could lead to a collision. Drawing on work in earlier studies, the conflicts were identified and categorized based on observed precautionary braking, precautionary change of direction, emergency braking, emergency change of direction, and/or full stop by either the motorist or cyclist (Allen et al., 2005; Atkins, 2005; Carter et al., 2007; Hunter, 2000).

Due to the small number of conflicts, 56 hours of additional video were viewed only to collect additional data on conflicts. Two additional hours were selected of before video and two more of after video for a total of four additional hours at each location. Generally, an additional peak hour or a saddle peak hour (e.g., if the original peak hour reviewed was 4:45-5:45 p.m., this additional review may have taken 3:45-4:45 p.m.), and an additional off-peak hour were selected for review. In several cases, the two additional hours were selected from both an AM peak and a PM peak (rather than one peak and one off-peak hour). This was done in the case of the Southwest Terwilliger Boulevard at Taylors Ferry Road intersection because it was hypothesized that there may be a significant reverse peak flow at these locations (in part because of the proximity to Lewis and Clark College). For this additional video, only conflicts and total rightturning and bicycle volumes were recorded.

The initial coding schema for user behavior, compliance, and conflicts failed to capture an important behavioral outcome of the bicycle box - yielding of right-turning traffic to through cyclists. To partially address this question, we reviewed an additional 17 hours of video at two treatment intersections and one control location where the field of view allowed us to accurately categorize yielding as either no interaction; car yielded to cyclist(s); car yielded but not exclusively to cyclists (e.g., to a pedestrian); cyclist actively yielded to car; or car failed to yield (e.g., cut off the cyclist). We also recorded the number of cyclists that proceeded through the intersection before the yielding car made their turn.

\subsection{CYCLIST AND MOTORIST SURVEYS}

Cyclist and motorist surveys were conducted to assess knowledge and understanding of the bike boxes, perceptions of safety, and other reactions to the treatments. The intercept survey of cyclists collected data from five bike box intersections. The five locations were chosen based upon bicycle volumes and to get a variety of intersection types and locations. A sign indicating "Bike Survey Ahead" was placed on the side of the road in advance of the bike box. Research assistants stood on the sidewalk adjacent to the bike box wearing a safety vest, and asked all stopped cyclists to take a postcard explaining the survey. In two cases, postcards were handed out one to two blocks upstream of the bike box due to a higher percentage of cyclists stopping for a red light at those upstream positions. The postcard included a website address for the survey and a unique identification number. That number was to be entered by the respondent, so as to avoid responses from people not sampled at the intersections. A total of 997 postcards were distributed and 468 valid responses were received - a $47 \%$ response rate. The postcards were distributed between September 30 and October 18, 2009, and the cyclists were asked to complete the survey by the end of October 2009.

Due to safety and legal constraints, it was not possible to intercept motorists or use license plate data to survey motorists traveling through the intersections. Instead, the City of Portland sent an 
email invitation to people working downtown to take the survey. The sample was from people who signed up to receive information from a city demand management program to address traffic problems related to light-rail construction in the downtown area. The sample only included people who indicated that they did drive to work downtown, at least part-time. While many employees in the sample were seeking information on alternatives to driving downtown, others may have only participated because of prize incentives the city offered. The analysis presented here attempts to control for potential respondent bias by looking at several subgroups of respondents, including non-cyclists and people not expressing pro-bike attitudes. Of the 3,020 people invited to participate, 721 responded, for a $24 \%$ response rate. For both the motorist and cyclist survey, respondents could enter a drawing for gift cards as an incentive to improve the response rate. Both surveys were reviewed and approved by Portland State University's Human Subjects Research Review Committee.

\subsection{FRICTION TESTING}

In order to assess whether the green thermoplastic surface alters roadway friction, and thus the stopping distance, a simple friction test was conducted based on a methodology used in Bartlett et al. (2006). In this data collection, we neglect the difference between motor vehicles and bicycle tires (composition and contact area). We dragged a drag sled (consisting of a 20.75 pound section of concrete-filled, rubber car tire attached to a hanging weight scale) parallel across the surface being measured in the direction of traffic flow. The scale reading was monitored as the tool was slowly dragged across the surface, with the reading recorded four seconds into the drag (in order to minimize extreme readings due to initializing the drag). Any readings taken when the sled was jerking or bouncing were thrown out. A drag factor was calculated by taking the average of five recordings at each location and dividing by the weight of the sled. Drag factors were calculated at a variety of locations, including on the green thermoplastic surface (both on sections that appeared to be worn and unworn), on white stop bars and lane stripes, and on adjacent asphalt. These measurements were taken on August 4, 2009, and July 1, 2010. 


\subsection{RESULTS}

\subsection{VIDEO SURVEILLANCE}

The object of the video surveillance was to obtain empirical evidence of motorist and cyclist compliance, comprehension and use of the new bike boxes (these will be referred to as behavioral measures) and surrogate measures of safety. For all measures, the data are presented in the same manner in Tables 2-6. The before-and-after behavioral counts and the normalizing variable are organized by treatment type (color or no color) and control locations. The sample proportions (behavior counts / normalizing counts) are presented. The p-value of the two population proportions test is reported $\left(H_{o}: p_{1}-p_{2}=0\right)$. Comparisons that are statistically significant for rejecting the null hypothesis at the $95^{\text {th }}$ percentile confidence are bolded. For convenience, the direction of the proportion change is indicated in the last column (+ increase from before to after, - a decrease from before to after).

\subsubsection{Motorist Behavior}

\subsubsection{Encroachment in the Crosswalk}

The encroachment of every motor vehicle that arrived during a red signal into the crosswalk was observed and recorded. These counts were normalized by the number of motor vehicles arriving on red. Note that only the vehicle at the front of the queue at the red light was recorded (any other vehicle that arrives cannot encroach). These results are presented in Table 2. 
Table 2 Motor Vehicle Encroachment in Crosswalk

\begin{tabular}{|c|c|c|c|c|c|c|c|c|}
\hline \multirow[b]{2}{*}{ Treatment Type } & \multicolumn{2}{|c|}{$\begin{array}{c}\text { Motor Vehicles } \\
\text { Encroaching }\end{array}$} & \multicolumn{2}{|c|}{$\begin{array}{c}\text { Motor Vehicles } \\
\text { Arriving on Red } \\
\text { Signal }\end{array}$} & \multicolumn{2}{|c|}{ Sample Proportion } & \multirow[b]{2}{*}{ p-value } & \multirow{2}{*}{$\begin{array}{l}\text { Dir. } \\
\text { Change }\end{array}$} \\
\hline & Before & After & Before & After & Before & After & & \\
\hline \multicolumn{9}{|l|}{ All Encroachments } \\
\hline Color & 244 & 58 & 977 & 916 & 0.250 & 0.063 & 0.000 & - \\
\hline No Color & 66 & 20 & 357 & 335 & 0.185 & 0.060 & 0.000 & - \\
\hline Control & 28 & 32 & 270 & 239 & 0.104 & 0.134 & 0.265 & \\
\hline \multicolumn{9}{|c|}{ Minor Encroachments } \\
\hline Color & 149 & 13 & 977 & 916 & 0.153 & 0.014 & 0.000 & - \\
\hline No Color & 26 & 1 & 357 & 335 & 0.073 & 0.003 & 0.000 & - \\
\hline Control & 9 & 18 & 270 & 239 & 0.033 & 0.075 & 0.031 & + \\
\hline \multicolumn{9}{|c|}{ Moderate Encroachments } \\
\hline Color & 58 & 6 & 977 & 916 & 0.059 & 0.007 & 0.000 & - \\
\hline No Color & 14 & 1 & 357 & 335 & 0.039 & 0.003 & 0.001 & - \\
\hline Control & 3 & 4 & 270 & 239 & 0.011 & 0.017 & 0.584 & \\
\hline \multicolumn{9}{|c|}{ Major Encroachments } \\
\hline Color & 37 & 39 & 977 & 916 & 0.038 & 0.043 & 0.595 & \\
\hline No Color & 26 & 18 & 357 & 335 & 0.073 & 0.054 & 0.289 & \\
\hline Control & 16 & 10 & 270 & 239 & 0.059 & 0.042 & 0.362 & \\
\hline
\end{tabular}

The video data showed that motorist encroachment into the pedestrian crosswalk fell significantly compared to the control intersections. The change in all motor vehicle encroachments in the crosswalk per motorists arriving on red was virtually eliminated: color (before $=0.250$, after $=0.063, \mathrm{p}=0.000$ ); no color locations (before $=0.185$, after $=0.060, \mathrm{p}=0.000$ ); and control (before $=0.104$, after $=0.134, \mathrm{p}=0.000$ ). This reduction of motor vehicles entering the crosswalk has the potential to improve pedestrian safety.

\subsubsection{Encroachment in the Bike Lane}

The intended action for right-turning motorists is to remain in the motor vehicle lane and yield to bicycles until there is a gap. The encroachment of every right-turning vehicle in the bicycle lane was observed and recorded for three conditions: 1) while making a right-turn (i.e., making a wide turn that passes through a portion of the bicycle lane), 2) prior to the intersection (i.e., moving from the vehicle travel lane into the bicycle lane in advance of the intersection), and 3) while stopped waiting to waiting to make a right turn. These behaviors were normalized by rightturning vehicles. A summary of these counts is given in Table 3. Note that at one of the treatment intersections (Southwest Broadway at $6^{\text {th }}$ Avenue) right turns are not allowed; thus it was excluded from this analysis (and the conflict analysis). 
Table 3 Motor Vehicle Encroachment in Bike Lane

\begin{tabular}{|c|c|c|c|c|c|c|c|c|}
\hline \multirow[b]{2}{*}{ Treatment Type } & \multicolumn{2}{|c|}{$\begin{array}{l}\text { Motor Vehicles } \\
\text { Encroaching in } \\
\text { Bicycle Lane }\end{array}$} & \multicolumn{2}{|c|}{$\begin{array}{l}\text { Motor Vehicles } \\
\text { Turning Right }\end{array}$} & \multicolumn{2}{|c|}{ Sample Proportion } & \multirow[b]{2}{*}{ p-value } & \multirow{2}{*}{$\begin{array}{l}\text { Dir. } \\
\text { Chang } \\
\text { e }\end{array}$} \\
\hline & Before & After & Before & After & Before & After & & \\
\hline \multicolumn{9}{|l|}{ All Encroachments } \\
\hline Color & 619 & 755 & 1871 & 1973 & 0.331 & 0.383 & 0.000 & + \\
\hline No Color & 61 & 179 & 491 & 552 & 0.124 & 0.324 & 0.000 & + \\
\hline Control & 344 & 324 & 361 & 363 & 0.953 & 0.893 & 0.000 & - \\
\hline \multicolumn{9}{|c|}{ While Making a Right-turn } \\
\hline Color & 505 & 718 & 1871 & 1973 & 0.270 & 0.364 & 0.000 & + \\
\hline No Color & 42 & 163 & 491 & 552 & 0.086 & 0.295 & 0.000 & + \\
\hline Control & 280 & 298 & 361 & 363 & 0.776 & 0.821 & 0.042 & + \\
\hline \multicolumn{9}{|c|}{ Prior to Arriving at Intersection } \\
\hline Color & 66 & 22 & 1871 & 1973 & 0.035 & 0.011 & 0.000 & - \\
\hline No Color & 9 & 6 & 491 & 552 & 0.018 & 0.011 & 0.309 & \\
\hline Control & 57 & 14 & 361 & 363 & 0.158 & 0.039 & 0.000 & - \\
\hline \multicolumn{9}{|c|}{ While Stopped at Red Signal Indication } \\
\hline Color & 48 & 15 & 1871 & 1973 & 0.026 & 0.008 & 0.000 & - \\
\hline No Color & 10 & 10 & 491 & 552 & 0.020 & 0.018 & 0.789 & \\
\hline Control & 7 & 12 & 361 & 363 & 0.019 & 0.033 & 0.244 & \\
\hline
\end{tabular}

Note: excludes SW Broadway and 6th Ave

The installation of the bike box had mixed effects on motor vehicle encroachment in the bicycle lane. The tendency of motor vehicles to enter the bicycle lane in preparation for a right turn in advance of the intersection decreased for both the colored and non-colored locations (as well as for the control locations, the reason for which is not clear). The change at the color locations was statistically significant (before $=0.035$, after $=0.011, \mathrm{p}=0.000$ ); the no-color location was not (before $=0.018$, after $=0.011, \mathrm{p}=0.309$ ). The proportion of encroachments in the bike lane while stopped at a red signal per right-turning vehicle also decreased at color (before $=0.026$, after $=$ $0.008, \mathrm{p}=0.000$ ) and no-color locations (before $=0.020$, after $=0.018, \mathrm{p}=0.789$ ), but was not statistically significant at the no-color locations. The normalizing of these encroachments by total right-turning volumes or by stopping vehicles produced the same conclusion.

The data show that a higher proportion of motor vehicles encroached in the bike lane while making a right turn. This increase was statistically significant for both the colored and noncolored boxes: color (before $=0.270$, after $=0.364, p=0.000$ ) and no-color locations (before $=0.086$, after $=0.295, \mathrm{p}=0.000$ ). The video data reveal that with the bike box present, vehicles tended to start their turn further from the intersection (possibly encouraged by the missing solid bike-lane stripe). Clearly, this behavior is also influenced by the intersection geometry and the result was not found at all intersections. In addition, we did not code the severity of the encroachment as with other behaviors. A re-review of many of the intersections found this encroachment minor at most intersections, except at Southwest Broadway and Taylor (which exhibited the largest decrease in conflicts). Whether this increased encroachment while turning poses an increased safety risk is unclear. 


\subsubsection{Compliance Analysis}

Because there was no bike box in the before condition, we made two analyses of the encroachment of motor vehicles in the bike box. Normalizing counts in both conditions were the number of motor vehicles arriving on red. First, we compared the before motor vehicle encroachment in the crosswalk to the after encroachment in the bike box. Our assumption was that these behaviors are comparable since the motorist is required to stop prior to the stop bar in both designs. The results of this analysis are presented in Table 4. Second, we compared the encroachment of motor vehicles in the bike box (categorized by minor, moderate and major) by color or no color. Table 5 summarizes these results.

Table 4 Motor Vehicle Encroachment in Crosswalk (Before) and Bike Box (After)

\begin{tabular}{|c|c|c|c|c|c|c|c|c|}
\hline $\begin{array}{l}\text { Intersection } \\
\text { Type }\end{array}$ & $\begin{array}{l}\text { Motor Veh } \\
\text { Encroachir } \\
\text { Crosswalk }\end{array}$ & $\begin{array}{l}\text { Bike } \\
\text { Box }\end{array}$ & $\begin{array}{l}\text { Motor Vehi } \\
\text { Arriving on } \\
\text { Signal } \\
\text { Crosswalk } \\
\end{array}$ & $\begin{array}{l}\text { les } \\
\text { Red } \\
\text { Bike } \\
\text { Box } \\
\end{array}$ & $\begin{array}{l}\text { Sample Pro } \\
\text { Crosswalk }\end{array}$ & $\begin{array}{l}\text { ortion } \\
\text { Bike } \\
\text { Box } \\
\end{array}$ & p-value & $\begin{array}{c}\text { Dir. } \\
\text { Change }\end{array}$ \\
\hline Color & 244 & 259 & 977 & 916 & 0.250 & 0.283 & 0.068 & \\
\hline No Color & 66 & 76 & 357 & 335 & 0.185 & 0.227 & 0.134 & \\
\hline All & 310 & 335 & 1334 & 1251 & 0.232 & 0.268 & 0.020 & + \\
\hline
\end{tabular}

Table 5 Motor Vehicle Encroachment in Bike Box

\begin{tabular}{lcclccccc}
\hline & \multicolumn{9}{c}{$\begin{array}{l}\text { Motor Vehicles } \\
\text { Motor Vehicle } \\
\text { Entering Bike Box }\end{array}$} & $\begin{array}{l}\text { Arriving on Red } \\
\text { Signal }\end{array}$ & \multicolumn{2}{l}{ Sample Proportion } & & Dir. \\
Treatment Type & No Color & Color & No Color & Color & No Color & Color & p-value & Change \\
\hline All Encroachments & 76 & 259 & 335 & 916 & 0.227 & 0.283 & $\mathbf{0 . 0 2 8}$ & + \\
Minor & 39 & 123 & 335 & 916 & 0.116 & 0.134 & 0.378 & \\
Moderate & 11 & 43 & 335 & 916 & 0.033 & 0.047 & 0.269 & \\
Major & 26 & 93 & 335 & 916 & 0.078 & 0.102 & 0.184 & \\
\hline
\end{tabular}

Because bike boxes are uncommon in the U.S., a major objective of this study was to assess compliance with the pavement markings, which were new to most drivers. The video surveillance data showed good compliance rates with the new traffic-control devices. Overall, $73.2 \%$ of stopping motor vehicles did not encroach at all in the bike box. While this was a lower and statistically significant proportion when compared to stopping motorists' encroachment in the crosswalk prior to installation $(76.8 \%, \mathrm{p}=0.02)$, this result is not unexpected or concerning. The box requires motorists to stop at an increased distance from the intersection and more encroachments should be expected. Since motorists are quite familiar with the stopping expectation for crosswalks, the similarity of the behavior is a strong indication that motorists understand the traffic control. 


\subsubsection{Cyclist Behavior}

\subsubsection{Encroachments}

For each cyclist that arrived during a red signal, we recorded if the cyclist stopped with any part of the bicycle entering the crosswalk (defined by pavement markings). The normalizing count was the number of cyclists arriving on red. A summary of these observations is presented in Table 6.

Table 6 Cyclist Encroachment in Crosswalk

\begin{tabular}{|c|c|c|c|c|c|c|c|c|}
\hline \multirow[b]{2}{*}{ Treatment Type } & \multicolumn{2}{|c|}{$\begin{array}{r}\text { Cyclists Entering } \\
\text { Crosswalk }\end{array}$} & \multicolumn{2}{|c|}{$\begin{array}{r}\text { Cyclists Arriving } \\
\text { on Red Signal }\end{array}$} & \multicolumn{2}{|c|}{ Sample Proportion } & \multirow{2}{*}{$\begin{array}{l}\text { p- } \\
\text { value }\end{array}$} & \multirow{2}{*}{$\begin{array}{r}\text { Dir. } \\
\text { Change }\end{array}$} \\
\hline & Before & After & Before & After & Before & After & & \\
\hline Color & 134 & 130 & 328 & 523 & 0.409 & 0.249 & 0.000 & - \\
\hline No Color & 15 & 16 & 66 & 128 & 0.227 & 0.125 & 0.046 & - \\
\hline Control & 4 & 5 & 20 & 22 & 0.200 & 0.227 & 0.813 & \\
\hline
\end{tabular}

As with motorists, the video data showed that cyclist encroachment into the pedestrian crosswalk fell significantly compared to the control intersections. After the installation of the bike boxes, the proportion of cyclists entering the crosswalk per cyclist arriving on red was statistically significantly lower for both the color (before $=0.409$, after $=0.249, \mathrm{p}=0.000$ ) and no-color locations (before $=0.227$, after $=0.125, p=0.046$ ). There was not a statistically significant change at the control locations (before $=0.200$, after $=0.227, p=0.813$ ), though far fewer cyclists were observed. As with the motorist reduction in crosswalk encroachments, this reduction of cyclists entering the crosswalk area has the potential to improve pedestrian safety.

\subsubsection{Cyclists Position in the Bike Box}

The final behavior we analyzed was the stopping location of cyclists in the box. Cyclist stopping position was recorded according to the locations identified in Figure 4, including the portion of the box directly in front of the motor vehicle lane (location A), the portion of the box in front of the motor vehicle stop bar but in line with the approaching bike lane (location $\mathrm{B}$ ), in the bike lane behind the stop bar (location C), and other (location D). Those cyclists that continued through the intersection without stopping (usually due to arrival on a green signal), are marked as "did not stop." The results are summarized by treatment type in Table 7. The rows labeled "Bike in Location B" indicate the stopping location of cyclists when a bicycle was already stopped in B. The row labeled "No other bike present" indicates the stopping location when no other bike was present. 
Table 7 Stopping Position of Cyclist in Bike Box

\begin{tabular}{llrrrrr}
\hline & & \multicolumn{3}{c}{ Stopping Location } & \multicolumn{3}{c}{ Did Not } \\
Treatment & Other Cyclist & A & B & C & D & Stop \\
\hline Color & No other bike present & 20 & 343 & 2 & 107 & 1711 \\
& Bike in Location B & 16 & -- & 20 & 0 & \\
& Subtotal & 36 & 343 & 22 & 107 & 1711 \\
\hline \multirow{2}{*}{ No Color } & No other bike present & 9 & 58 & 2 & 14 & 514 \\
& Bike in Location B & 12 & -- & 25 & 0 & \\
& Subtotal & 21 & 58 & 27 & 14 & 514 \\
\hline Total & & 57 & 401 & 49 & 121 & 2225 \\
\hline
\end{tabular}

The video data reveal that the majority of cyclists understood that they were to stop ahead of the motor vehicle traffic. When no other bike was present $(n=555), 73 \%$ of the stopping cyclists correctly stopped ahead of the motor vehicle stop line and behind the crosswalk (location A or B in Figure 4), though only 5\% stopped in the area of the box directly in front of where a motor vehicle would stop and to the left of the bicycle lane (location A). When a cyclist was present in location $B(n=73), 38 \%$ of the stopping cyclists chose to stop in the box in front of the motor vehicle area (location A), while $62 \%$ chose to stop behind the existing bike in location $\mathrm{C}$. Use of the full area of the bike box (i.e., location A) was more likely at higher bike volume locations and at the two locations where the bike lane ends downstream of the bike box (Northwest Broadway and Hoyt and Southwest Broadway and $6^{\text {th }}$ Avenue).

\subsubsection{Safety}

\subsubsection{Conflicts}

We analyzed two surrogate measures of safety (conflicts and yielding behavior) to assess the change in safety performance. For each hour of video data (five hours before and after), we counted the number and severity of conflicts, the number of cyclists, and the number of rightturning cars. These data are aggregated and are presented in Table 8. The count change in conflicts and the percentage change of the exposure measures are also shown. Note at the control locations, no conflicts were observed either before or after.

The effects of the bike boxes on safety were assessed by comparing before-and-after behaviors (including conflicts) at the treatment and control intersections, as well as perceptions of safety through the motorist and cyclist surveys. Overall, the number of observed conflicts decreased from 29 to 20 while the total number of cyclists increased $94 \%$ and motor vehicle right-turn volumes increased by $15 \%$. Only one location saw an increase in conflicts - Northwest Everett at $16^{\text {th }}$ Avenue. At this location, the geometry of the intersection encourages higher speed rightturns (most vehicles are turning to the far left lane of a three-lane one-way street to enter a freeway). This was a problem prior to the installation of the bike box, and the city installed a curb-bulb out to partially mitigate this problem. 
Table 8 Summary of Conflicts

\begin{tabular}{|c|c|c|c|c|c|c|c|c|c|}
\hline \multirow[b]{2}{*}{ Intersections } & \multicolumn{2}{|c|}{ Pre (44 hours) } & \multicolumn{4}{|c|}{ Post (45 hours) } & \multirow{2}{*}{$\begin{array}{l}\text { Count } \\
\text { Change } \\
\text { in } \\
\text { Conflic } \\
\text { ts }\end{array}$} & \multicolumn{2}{|c|}{$\%$ Change in } \\
\hline & $\begin{array}{l}\text { Conf } \\
\text { licts }\end{array}$ & Cyclists & $\begin{array}{l}\text { Turni } \\
\text { ng } \\
\text { Cars } \\
\end{array}$ & $\begin{array}{l}\text { Confli } \\
\text { cts }\end{array}$ & Cyclists & $\begin{array}{l}\text { Turni } \\
\text { ng } \\
\text { Cars } \\
\end{array}$ & & Cyclists & $\begin{array}{l}\text { Turni } \\
\text { ng } \\
\text { Cars }\end{array}$ \\
\hline \multicolumn{10}{|c|}{ Color } \\
\hline $\begin{array}{l}\text { W Burnside \& 14th } \\
\text { Ave }\end{array}$ & 1 & 57 & 97 & 1 & 98 & 301 & 0 & $72 \%$ & $210 \%$ \\
\hline NW Everett \& 16th & 2 & 92 & 1464 & 7 & 192 & 1641 & 5 & $109 \%$ & $12 \%$ \\
\hline $\begin{array}{l}\text { SE 11th \& } \\
\text { Hawthorne }\end{array}$ & 3 & 441 & 356 & 2 & 631 & 358 & -1 & $43 \%$ & $1 \%$ \\
\hline $\begin{array}{l}\text { SE 7th \& } \\
\text { Hawthorne }\end{array}$ & 2 & 431 & 183 & 2 & 779 & 222 & 0 & $81 \%$ & $21 \%$ \\
\hline SW 3rd \& Madison & 2 & 404 & 159 & 1 & 795 & 197 & -1 & $97 \%$ & $24 \%$ \\
\hline $\begin{array}{l}\text { SW Broadway \& } \\
\text { Taylor }\end{array}$ & 15 & 247 & 770 & 6 & 348 & 867 & -9 & $41 \%$ & $13 \%$ \\
\hline $\begin{array}{l}\text { SW } 6^{\text {th }} \& \\
\text { Broadway }\end{array}$ & 0 & 34 & 3 & 0 & 58 & 5 & 0 & $71 \%$ & $67 \%$ \\
\hline \multicolumn{10}{|c|}{ No Color } \\
\hline $\begin{array}{l}\text { NW Broadway \& } \\
\text { Hoyt }\end{array}$ & 4 & 275 & 411 & 1 & 964 & 414 & -3 & $251 \%$ & $1 \%$ \\
\hline $\begin{array}{l}\text { SW Terwilliger \& } \\
\text { Taylors Ferry, NB }\end{array}$ & 0 & 21 & 216 & 0 & 29 & 234 & 0 & $38 \%$ & $8 \%$ \\
\hline $\begin{array}{l}\text { SW Terwilliger \& } \\
\text { Taylors Ferry, SB }\end{array}$ & 0 & 23 & 254 & 0 & 28 & 262 & 0 & $22 \%$ & $3 \%$ \\
\hline Subtotal Boxes & 29 & 2025 & 3913 & 20 & 3922 & 4501 & -9 & $94 \%$ & $15 \%$ \\
\hline \multicolumn{10}{|c|}{ Control } \\
\hline NE $16^{\text {th }} \&$ Weidler & 0 & 82 & 134 & 0 & 55 & 145 & 0 & $-33 \%$ & $8 \%$ \\
\hline $\mathrm{NE} 7^{\text {th }} \&$ Weidler & 0 & 92 & 227 & 0 & 69 & 218 & 0 & $-25 \%$ & $-4 \%$ \\
\hline Total & 29 & 2199 & 4274 & 20 & 4046 & 4864 & -9 & & \\
\hline
\end{tabular}

Excluding the control locations, Figure 5 shows the hourly before-to-after conflict counts by intersection and the corresponding number of cyclists and right-turning motor vehicles. In the figure, the radius of the circles is proportional to hourly number of conflicts. The outline of the circle identifies the intersection of the count in the legend (color needed to view). In the before figure region, the largest hourly count of conflicts (5) is labeled. White filled circles are zero conflicts. By comparing the before-to-after panels, the overall decrease in conflicts (9) is shown by the decrease in the majority of size of the circles. The figure also shows how the individual intersections changed based on changes in cycle and right-turning car volumes. Further inspection of the figure, shows the largest decrease in conflicts was at Southwest Broadway at Taylor. The increase in hourly conflicts at Northwest Everett at $16^{\text {th }}$ is also clear.

In an attempt to control for changes in exposure shown in these data, we estimated negativebinomial (NB) models for the number of conflicts as a function of cycle and right-turning volumes. Conflict data has many of the same properties and challenges encountered in crash 
data, and NB models are perhaps the most common approach to crash-frequency modeling (Lord and Mannering, 2010). We estimated models separately for the before-and-after data and then compared the predictions. The model results are shown in Table 9. Model fits were reasonable (null deviance: 58.58, residual deviance: 33.88 on 37 degrees of freedom, pseudo $\mathrm{R}^{2} 0.42$ (from Cameron and Trivedi, 1998), after: null deviance: 46.73, residual deviance: 27.79 on 42 degrees of freedom, pseudo $\mathrm{R}^{2} 0.41$, in both models coefficients for turning cars and cyclist significant at the 0.05 level).

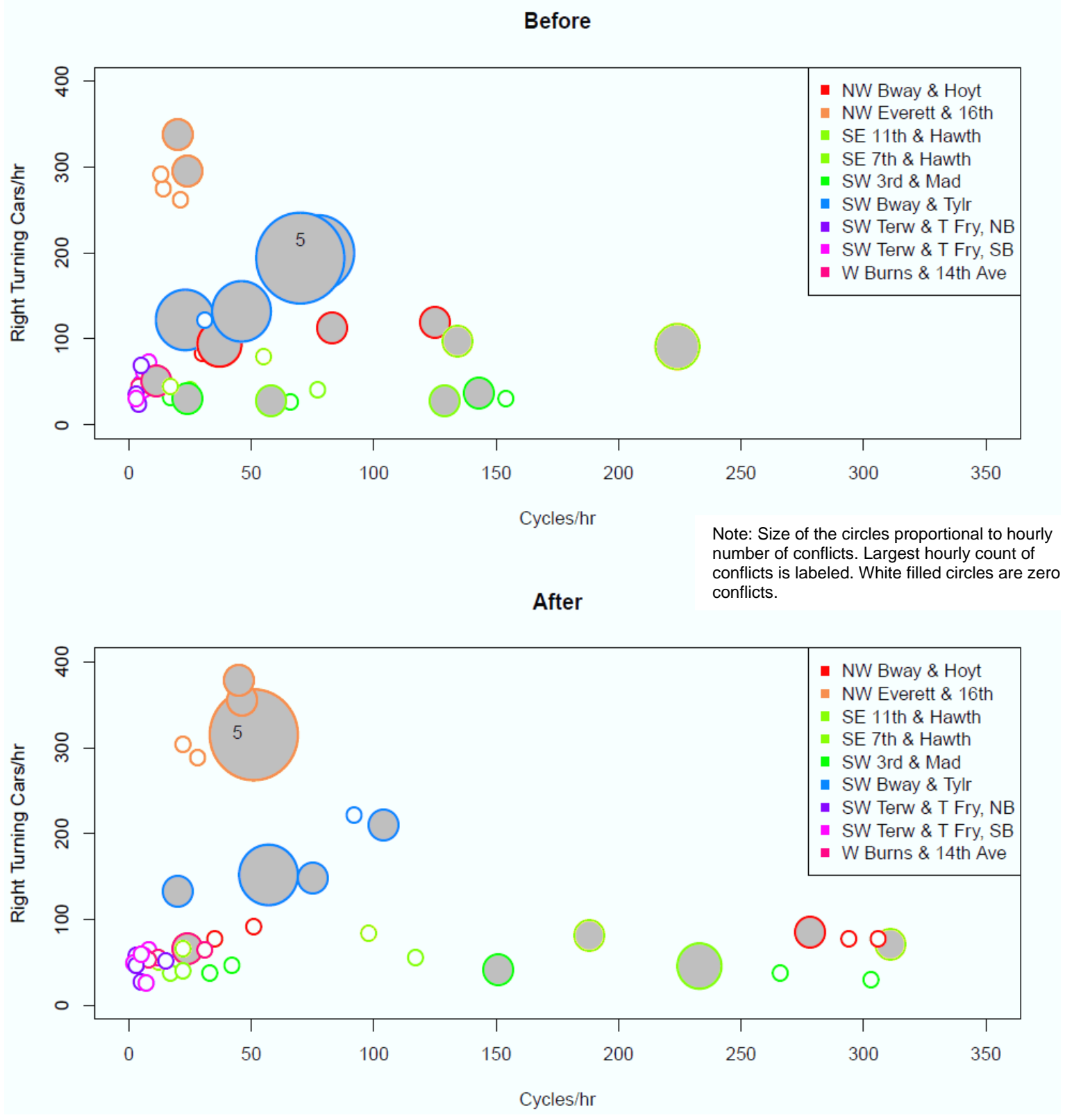

Figure 5 Before and After Hourly Conflict Counts by Intersection 
Table 9 Model Results

\begin{tabular}{|c|c|c|c|c|c|}
\hline \multirow[t]{2}{*}{ Model } & \multicolumn{3}{|c|}{ Estimated coefficients (standard error) } & \multirow{2}{*}{$\begin{array}{l}\text { Null } \\
\text { Deviance }\end{array}$} & \multirow{2}{*}{$\begin{array}{l}\text { Residual } \\
\text { Deviance }\end{array}$} \\
\hline & Bo & $\ln ($ cycle/hr) & $\begin{array}{l}\text { In(vehicles } \\
\text { turn rt/hr) }\end{array}$ & & \\
\hline $\begin{array}{l}\text { Conflicts } \\
\text { Before }\end{array}$ & $\begin{array}{l}-7.4130(1.9194) \\
p=0.000112\end{array}$ & $\begin{array}{l}0.7643(0.2272) \\
p=0.000770\end{array}$ & $\begin{array}{l}0.9387(0.2944) \\
p=0.001427\end{array}$ & $\begin{array}{l}58.583 \\
\text { dof }=39\end{array}$ & $\begin{array}{l}33.884 \\
\text { dof }=37\end{array}$ \\
\hline $\begin{array}{l}\text { Conflicts } \\
\text { After }\end{array}$ & $\begin{array}{l}-9.3416(2.6278) \\
p=0.000378\end{array}$ & $\begin{array}{l}0.6521(0.2863) \\
p=0.022738\end{array}$ & $\begin{array}{l}1.2570(0.3756) \\
p=0.000819\end{array}$ & $\begin{array}{l}46.726 \\
\text { dof }=44\end{array}$ & $\begin{array}{l}27.791 \\
\text { dof }=42\end{array}$ \\
\hline
\end{tabular}

We created the contour plot in Figure 6 to explore how the number of conflicts per hour varies with exposure by subtracting the fitted models in Table 9 . In the figure, the $x$-axis is the cycle volume per hour, the $y$-axis is the right-turning motor vehicle volumes per hour, and the isocontours show the modeled difference between the number of conflicts after (with bike box) and before (no bike box). Over all ranges of both exposures, fewer conflicts are predicted with the bike box (i.e., all isocontours are negative). In both models, the estimated coefficients for right-turning volumes are greater than cycle volume.

The purpose of this modeling was not to develop predictive models of the number of conflicts reduced by bike boxes rather only to explore how cycle and right-turning volumes influenced conflicts in our data. As shown in Figure 5, we had no data points in the upper limits of the figure (both volumes >200) so extrapolation of the estimates should be done with caution, if at all. Because of the small counts and observations there are clear limitations to this model. We also recognized that the hourly counts of the same intersection are not independent and explored a repeated measures approach. However, the before model did not converge though the after model had similar estimated coefficients to the NB model. Thus, we urge that these models be interpreted with recognition of their identified limitations. 


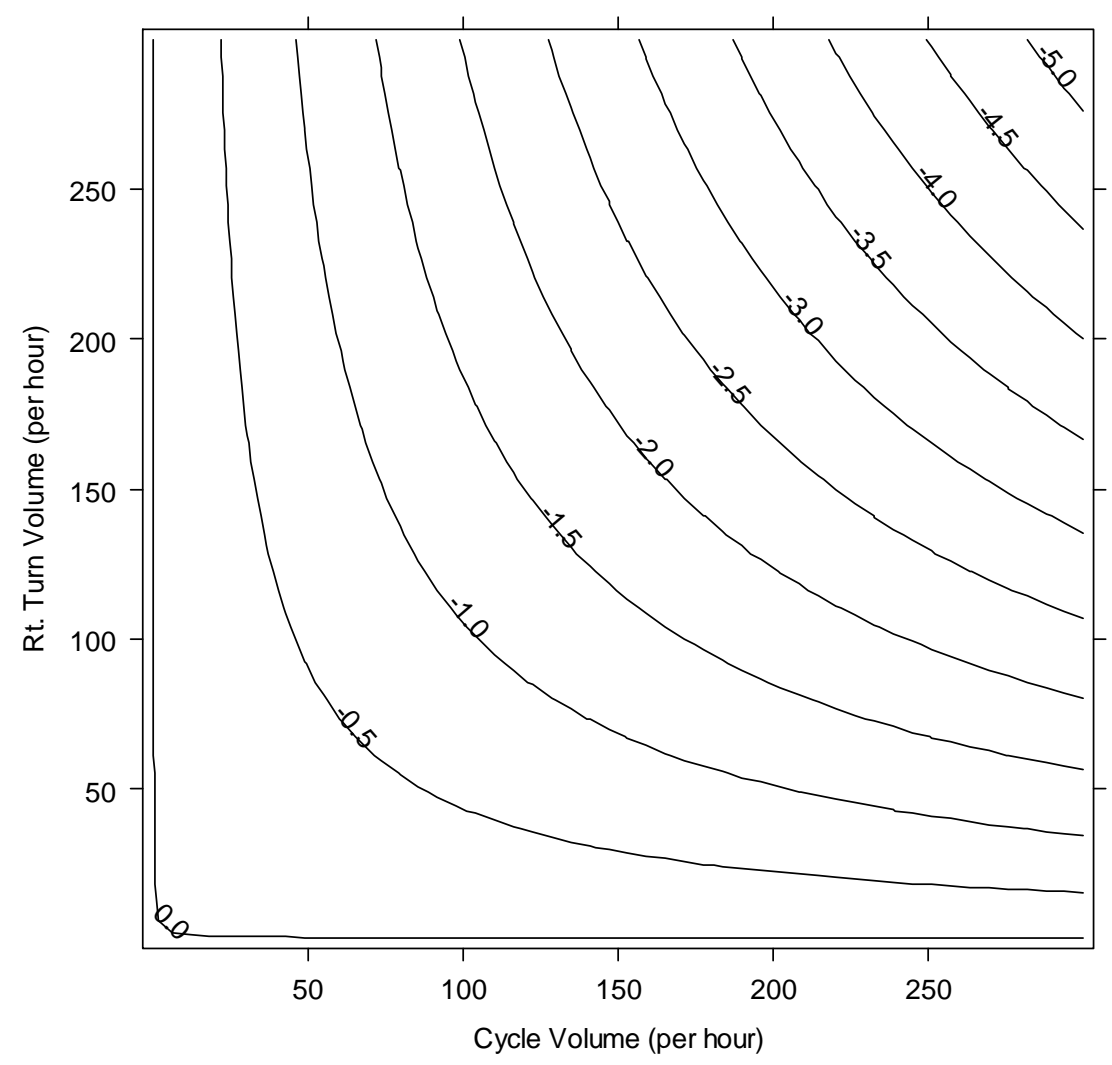

Figure 6 Isocontour plot of the difference between the estimated conflicts before and after per hour

\subsubsection{Yielding}

An analysis of the yielding behavior was conducted specifically for three intersections where the field of view allowed accurate characterization of the cyclist or motorists yielding behavior. The percent change for number of bicycles, right-turning cars and yielding behaviors are shown in Table 10 . 
Table 10 Summary of Yielding Behavior, Before (B) to After (A) Treatment

\begin{tabular}{|c|c|c|c|c|c|c|c|c|c|c|c|c|c|c|}
\hline \multirow[b]{3}{*}{ Intersection } & \multirow{2}{*}{\multicolumn{2}{|c|}{ Bicycles }} & \multirow{2}{*}{\multicolumn{2}{|c|}{$\begin{array}{l}\text { Rt. Turning } \\
\text { Motor } \\
\text { Vehicles }\end{array}$}} & \multirow{2}{*}{\multicolumn{2}{|c|}{$\begin{array}{l}\text { No } \\
\text { Interaction }\end{array}$}} & \multicolumn{8}{|c|}{ Yielding } \\
\hline & & & & & & & \multicolumn{2}{|c|}{$\begin{array}{l}\text { Motorist } \\
\text { to Cyclist }\end{array}$} & \multicolumn{2}{|c|}{$\begin{array}{l}\text { Motorist } \\
\text { to Other }\end{array}$} & \multicolumn{2}{|c|}{$\begin{array}{l}\text { Cyclist to } \\
\text { Motorist }\end{array}$} & \multicolumn{2}{|l|}{$\begin{array}{l}\text { Motorist } \\
\text { Fails to } \\
\text { Yield }\end{array}$} \\
\hline & B & $\mathbf{A}$ & B & $\mathbf{A}$ & B & $\mathbf{A}$ & B & $\mathbf{A}$ & B & $\mathbf{A}$ & B & $\mathbf{A}$ & B & $\mathbf{A}$ \\
\hline $\begin{array}{l}\text { NW Broadway } \\
\& \text { NW Hoyt } \\
\text { (no color) }\end{array}$ & 155 & 607 & 210 & 245 & 197 & 195 & 6 & 36 & 4 & 10 & 0 & 1 & 3 & 2 \\
\hline $\begin{array}{l}\text { SE Hawthorne } \\
\& \text { SE } 7^{\text {th }} \text { (color) }\end{array}$ & 296 & 640 & 118 & 130 & 109 & 89 & 7 & 37 & 2 & 2 & 0 & 0 & 0 & 2 \\
\hline \multirow[t]{2}{*}{$\begin{array}{l}\text { NE Weidler \& } \\
\text { NE } 7^{\text {th }} \text { (control) }\end{array}$} & 92 & 69 & 221 & 217 & 208 & 208 & 6 & 2 & 7 & 7 & 0 & 0 & 0 & 0 \\
\hline & \multicolumn{14}{|c|}{ Percent Change, Before to After } \\
\hline $\begin{array}{l}\text { NW Broadway } \\
\& \text { NW Hoyt } \\
\text { (no color) } \\
\text { SE Hawthorne } \\
\& \text { SE } 7^{\text {th }} \text { (color) }\end{array}$ & \multicolumn{2}{|c|}{$292 \%$} & \multicolumn{2}{|c|}{$17 \%$} & \multicolumn{2}{|c|}{$-1 \%$} & \multicolumn{2}{|c|}{$500 \%$} & \multicolumn{2}{|c|}{$150 \%$} & \multicolumn{2}{|c|}{-- } & \multicolumn{2}{|l|}{$-33 \%$} \\
\hline $\begin{array}{l}\text { NE Weidler \& } \\
\text { NE } 7^{\text {th }} \text { (control) }\end{array}$ & \multicolumn{2}{|c|}{$-25 \%$} & \multicolumn{2}{|c|}{$-2 \%$} & \multicolumn{2}{|c|}{$0 \%$} & \multicolumn{2}{|c|}{$-67 \%$} & \multicolumn{2}{|c|}{$0 \%$} & & & & \\
\hline
\end{tabular}

Our analysis of the three additional intersections for yielding behavior found an increase in the key behavior of right-turning cars yielding to cyclists at the treatment locations and a decrease at the control locations. At the two treatment locations there was an increase in cycle volumes $(292 \%, 116 \%)$, an increase in the right-turning cars $(17 \%, 10 \%)$. Cars yielding to cyclists increased by $500 \%$ and $429 \%$ after the installation of the bike box. The increase is partially driven by additional interactions as a result of increased volumes; however, the increase in yielding is proportionally more than the volume increase.

Because these intersections were selected for treatment on the basis of safety, there is the potential for these results to be biased by regression-to-the-mean in crash or conflict data. This bias could be controlled with a larger control sample; unfortunately, our two control locations did not provide sufficient data for these purposes. However, the two principal exposure measures increased from before to after; yet the conflicts decreased. We have made the assumption that the surrogate measure of conflicts is a predictor of actual crashes. We do not have the empirical data to verify this assumption. Overall, however, we feel confident that the overall reduction in conflicts and improvements in yielding is a positive change in safety performance.

\subsubsection{Effects of Color}

One objective of the study was to assess any differences between bike boxes with and without the green coloring. Unfortunately, the timing of the installation of the bike boxes resulted in a less than ideal comparison group between the color and no-color locations. As shown in Error! Reference source not found., the no-color locations have far fewer cyclists, vehicles and rightturning traffic than the colored locations. Two of the non-colored locations are also outside the 
central downtown core. Nonetheless, some observations can be made about the observed effects of color on motorist and cyclist behavior.

The share of motor vehicles arriving at a red signal encroaching in the green colored bike boxes was $28.3 \%$ compared to $22.7 \%$ for the no color boxes (Table 4 ). This is a significant difference $(\mathrm{p}=0.028)$. However, motor vehicle encroachment into the crosswalk at the no color locations prior to installation was also significantly lower. Therefore, the difference in bike box encroachment may be due to other intersection design or use factors.

Motor vehicle encroachment in the bike lane prior to arriving at the intersection decreased for color locations, but not no-color locations. Encroachments while making a right-turn or while waiting for red signals were not different. Measures of encroachment in the bike box by severity (minor, moderate, major) were no different for color, though the pooling of all results showed a higher proportion of encroachments for color locations. Colored marking did seem to influence the stopping location of cyclists. Chi-square test of position stopping proportions is significant $(\mathrm{p}=0.000)$. The color locations appear to encourage cyclists to stop ahead of the motor vehicle stop line, either in position B or A (with color 75\%, without color 66\%). Without color, a higher proportion $(23 \%)$ chose to stay in position $\mathrm{C}$ while only $5 \%$ did with color.

\subsection{CYCLIST AND MOTORIST SURVEYS}

This section presents highlights from the motorist and cyclist surveys related to the primary research questions. Complete survey results can be found in Appendix C.

\subsubsection{Did road users understand the markings?}

Both surveys aimed to assess in a number of ways whether respondents understood the bike boxes. Motorists were first shown two photos of bike boxes (with and without green) and asked if they had ever driven through an intersection with such a marking; 86\% indicated that they had done so. They were then asked an open-ended question, "What do you think the purpose of this pavement marking is?" Eighty-four percent included an answer that is consistent with the intent of the bike box, such as increasing visibility of cyclists, increasing safety, having cars stop back or bikes go ahead, minimizing conflict or right-hooks, etc. Of the remaining $16 \%$ of respondents, $8 \%$ only labeled the marking (e.g., "bike box" or "bike lane") without indicating the purpose; $6 \%$ did not answer; and $2 \%$ gave an answer that was not clearly consistent with the purpose, such as improving traffic flow or an area for bicycles to turn.

The next set of questions included graphic representations of two options for what to do when approaching an intersection with a bike box (though not labeled as such) when the light is red stopping behind the box or in the box. The first pair of diagrams did not include a bicycle and 94\% of respondents chose the correct response, stopping behind the box. The second pair included a bicycle positioned in the bike box, but to the far right, not directly in front of where the vehicle should stop. In this scenario, $89 \%$ of the respondents selected the correct response, a significantly lower share than in the first scenario $(\mathrm{p}<0.05)$. Table 11 shows differences in responses to these questions based upon the motorists' experiences. When shown photos of uncolored and green bike boxes, $89 \%$ of the motorists answered that they thought the green 
marking was better. When cyclists were asked an open-ended question about the purpose of the bike boxes, nearly all (97\%) gave a response that was consistent with the intent, including $52 \%$ who specifically mentioned the reduction of right-hook crashes.

Table 11 Surveyed Motorists' Understanding of Bike Boxes

\begin{tabular}{|c|c|c|c|c|c|c|c|c|c|c|c|}
\hline & \multirow{2}{*}{$\begin{array}{c}\text { All } \\
\text { Respon } \\
\text { dents }\end{array}$} & \multicolumn{2}{|c|}{$\begin{array}{c}\text { Has driven } \\
\text { through a } \\
\text { bike box }\end{array}$} & \multicolumn{2}{|c|}{$\begin{array}{c}\text { Remembers } \\
\text { billboard } \\
\text { about bike } \\
\text { boxes } \\
\end{array}$} & \multicolumn{2}{|c|}{ Is a cyclist } & \multicolumn{2}{|c|}{$\begin{array}{c}\text { Agrees that } \\
\text { City should } \\
\text { do more to } \\
\text { increase } \\
\text { cycling } \\
\end{array}$} & \multicolumn{2}{|c|}{$\begin{array}{c}\text { Has been } \\
\text { involved in a } \\
\text { near miss } \\
\text { with a cyclist, } \\
\text { as a motorist }\end{array}$} \\
\hline & & No & Yes & No & Yes & No & Yes & No & Yes & No & Yes \\
\hline \multicolumn{12}{|l|}{$\begin{array}{l}\text { Selected correct } \\
\text { stopping location } \\
\text { diagram... }\end{array}$} \\
\hline without bike in box & $94 \%$ & $\mathbf{8 8 \%}$ & $95 \%$ & $93 \%$ & $98 \%$ & $92 \%$ & $95 \%$ & $91 \%$ & $96 \%$ & $96 \%$ & $92 \%$ \\
\hline $\begin{array}{l}\text { with bike in box, in } \\
\text { far right area }\end{array}$ & $89 \%$ & $85 \%$ & $90 \%$ & $90 \%$ & $89 \%$ & $86 \%$ & $91 \%$ & $90 \%$ & $89 \%$ & $88 \%$ & $91 \%$ \\
\hline $\begin{array}{l}\text { Provided open ended } \\
\text { answer consistent } \\
\text { with bike box } \\
\text { purposes }\end{array}$ & $84 \%$ & $64 \%$ & $87 \%$ & $82 \%$ & $89 \%$ & $79 \%$ & $86 \%$ & $78 \%$ & $88 \%$ & $83 \%$ & $85 \%$ \\
\hline $\mathbf{n}$ & 721 & 100 & 617 & 536 & 181 & 219 & 497 & 299 & 417 & 392 & 321 \\
\hline
\end{tabular}

Both drivers and cyclists had largely positive reactions to the bike boxes. Over half $(52 \%)$ of the motorists $(n=717)$ felt that the bike boxes made driving safer at the intersections, while only $12 \%$ felt that it made driving more dangerous. Limiting the sample to motorists who are not cyclists $(n=219), 42 \%$ felt that that the bike boxes made driving at the intersections safer and $14 \%$ felt that they made driving more dangerous. Of those 219 drivers who are not cyclists, 33\% felt more comfortable driving through the intersections with the boxes (versus $16 \%$ less comfortable). However, $42 \%$ thought that the boxes made driving less convenient at the intersections. Finally, $37 \%$ thought drivers drove more safely because of the boxes, and 52\% thought the boxes made drivers more aware of cyclists generally. Drivers who were also cyclists $(n=497$, defined as owning a bicycle and bicycling at least once a month during the summer or remainder of the year) were generally more positive about the bike boxes.

Over three-quarters (77\%) of the cyclists said that the bike box they rode through when handed the survey postcard made the intersection safer for them as a cyclist, while only $2 \%$ felt it made the intersection more dangerous, $13 \%$ felt no difference, and 8\% did not know. In addition, $81 \%$ thought that motorists were more aware of cyclists because of the boxes, though $35 \%$ did not think that most motorists understood the purpose of the boxes.

\subsubsection{Did road users behave as intended?}

As mentioned, the video surveillance data showed good compliance rates with the new traffic control devices. Our motorist survey also supports this conclusion; 89\% of the motorists 
surveyed indicated that they understood that they were to stop behind the box. Perhaps unexpectedly, the rate was higher $(94 \%)$ when there was no bicycle present in the box. Respondents who had driven through a bike box; who remembered seeing a billboard about the bike boxes; who were also cyclists; who agreed that the city should be doing more to increase the number of cyclists; and who had been involved in a near miss with a cyclist were generally more likely to provide the correct stopping location and a consistent purpose in the open-ended question. However, even with the differences, at least $80 \%$ of most categories of motorists examined understood the boxes, using three different measures (Table 11). The one notable exception was that only $64 \%$ of the motorists who had not driven through a bike box provided a consistent answer to the open-ended question. When the respondents who did not provide any answer are omitted, the rate among inexperienced drivers goes up to $74 \%$.

\subsubsection{Are the markings improving safety?}

Both the motorist and cyclist surveys found an improvement in the perception of safety, though the improvement was greater for cyclists. Excluding drivers who are also cyclists (a conservative approach), survey respondents were more likely to think the boxes made driving in the intersection safer ( $42 \%$ vs. $14 \%$ more dangerous) and made them more comfortable driving through the intersection (33\% vs. $16 \%$ less comfortable). While comparable shares of drivers found the boxes inconvenient (42\%), the findings indicate that the boxes are likely to be improving awareness and safe driving behavior. Over half of the non-cycling drivers (52\%) thought that the boxes made drivers more aware of cyclists generally. The positive response from cyclists $-77 \%$ thought the boxes made the intersections safer for them vs. $2 \%$ more dangerous supports the secondary intent to increase cycling through improving perceptions of safety.

\subsubsection{Does color (green vs. no color) matter?}

The motorist survey showed a strong preference for the colored boxes. Eighty-nine percent of all respondents (and 90\% of non-cycling drivers) preferred the green bike box to the uncolored bike box.

\subsection{FRICTION TESTING}

We conducted a comparative assessment of the friction provided by the green thermoplastic, standard asphalt roadway surfacing and white roadway striping using a drag sled. Table 12 shows results of the friction tests, with each result being the average of five individual drags. 
Table 12 Friction Testing Results

\begin{tabular}{|c|c|c|c|}
\hline Location & Description & Surface & $\begin{array}{l}\text { Average } \\
\text { Drag }\end{array}$ \\
\hline SW $6^{\text {th }}$ and Broadway & $\begin{array}{l}\text { Bike lane (asphalt just prior to beginning of green } \\
\text { coloring) }\end{array}$ & Asphalt & 0.81 \\
\hline SW $6^{\text {th }}$ and Broadway & $\begin{array}{l}\text { Bike lane (in green at beginning of green coloring } \\
\text { area) }\end{array}$ & $\begin{array}{l}\text { Green } \\
\text { Thermoplastic }\end{array}$ & 0.87 \\
\hline SW $6^{\text {th }}$ and Broadway & $\begin{array}{l}\text { Grey spot on green coloring (seeming to indicate } \\
\text { wear), in bike lane portion of coloring }\end{array}$ & $\begin{array}{l}\text { Green } \\
\text { Thermoplastic }\end{array}$ & 0.60 \\
\hline SW $6^{\text {th }}$ and Broadway & $\begin{array}{l}\text { In bike lane, green area, just prior to white stop } \\
\text { bar }\end{array}$ & $\begin{array}{l}\text { Green } \\
\text { Thermoplastic }\end{array}$ & 0.68 \\
\hline SW Broadway and Jefferson & Bike lane, asphalt, no coloring & Asphalt & 0.77 \\
\hline SW Broadway and Jefferson & Motor vehicle lane, no coloring & Asphalt & 0.86 \\
\hline SW Broadway and Clay & Bike lane, green, by stop bar & $\begin{array}{l}\text { Green } \\
\text { Thermoplastic }\end{array}$ & 0.75 \\
\hline SW Broadway and Clay & Bike lane, area where coloring starts, in green & $\begin{array}{l}\text { Green } \\
\text { Thermoplastic }\end{array}$ & 0.84 \\
\hline SW Broadway and Clay & Bike lane, area where coloring starts, no green & Asphalt & 0.81 \\
\hline SW Broadway and Clay & Across motor vehicle stop bar prior to bike box & $\begin{array}{l}\text { White stop } \\
\text { bar }\end{array}$ & 0.86 \\
\hline SW Broadway and Clay & $\begin{array}{l}\text { Across bike lane white strip (Between bike lane } \\
\text { and motor vehicle lane) }\end{array}$ & $\begin{array}{l}\text { White } \\
\text { Striping }\end{array}$ & 0.80 \\
\hline \multicolumn{3}{|c|}{ Asphalt Average: } & 0.81 \\
\hline \multicolumn{3}{|c|}{ Green Thermoplastic Average: } & 0.75 \\
\hline \multirow{2}{*}{\multicolumn{3}{|c|}{$\begin{array}{r}\text { Green Thermoplastic Average (excluding worn section): } \\
\text { White stripe/bar average: }\end{array}$}} & 0.78 \\
\hline & & & 0.83 \\
\hline
\end{tabular}

The green surface had an average drag, across all locations, of 0.75 . Excepting a noticeably worn (and grey) section of the green thermoplastic, the average drag factor on the green was slightly higher at 0.78 . In comparison, the average drag factor on the asphalt was 0.81 , while the average drag factor on the white roadway markings (stop bars and lane stripes) was 0.83 . All of these values are acceptable and indicate that the thermoplastic markings have sufficient surface friction. 


\subsection{CONCLUSIONS}

The findings from both the video and survey data are generally positive. The bike boxes appear to be affecting behaviors that can improve safety for cyclists, and responses from both motorists and cyclists are far more favorable than negative. Compliance and understanding of the boxes by both motorists and cyclists is high and higher than found in several previous studies. This may be a result of the design (which includes instructions to "Wait Here" and prominent markings); the education efforts (including billboards, which $25 \%$ of the surveyed motorists remembered seeing); a high rate of compliance with traffic controls generally; and/or a high level of awareness of cyclists on the road. Most of the boxes were installed on routes that had high bicycle traffic volumes. Pedestrians appear to be benefiting through a reduction in encroachment into crosswalks. Overall, the number of conflicts fell and yielding behavior increased, which should lead to improvements in safety. The only potentially negative finding was an increased level of encroachment from motor vehicles into the bike lane while making a right turn.

However, the potential effect of this change on safety is unclear. Finally, the study's findings with respect to colored vs. uncolored bike boxes are also unclear due, in part, to the intersections examined. The video data did not reveal a significant difference in motor vehicle encroachment into the boxes with or without color, though the motorist survey revealed a strong preference for color. In addition, cyclists appear to use the box more as intended with the color, which should increase their visibility and improve safety.

The key findings in response to the research questions are as follows:

\section{Do cyclists and motorists understand and comply with the new bike box markings? Most motorists and cyclists appear to understand and comply with the markings.}

- Video analysis found that $77 \%$ of motorists stopped at the appropriate position before the installation (at the stop bar prior to the pedestrian crosswalk), while $73 \%$ stopped at the appropriate position after the installation (at the stop bar prior to the bike box). On a variety of measures in the survey, motorists indicated an understanding of the bike boxes of $86 \%$ or better.

- With the bike box in place, $73 \%$ of the stopping cyclists correctly stopped ahead of the motor vehicle stop line, though only $5 \%$ stopped in the area of the box directly in front of where a motor vehicle would stop. However, more cyclists (38\%) stopped in the bike box directly in front of where a motor vehicle would stop when other cyclists were already waiting in the box area.

- Cyclist encroachment in the crosswalk decreased significantly after the installation of the bike boxes, dropping from $41 \%$ to $25 \%$ of cyclists arriving on a red signal.

Do the bike boxes improve safety? After controlling for volumes, the number of conflicts decreased and yielding behavior increased. In addition, user perceptions of safety improved. 
- Conflicts: Overall, the number of observed conflicts decreased from 29 to 20 , while the total number of cyclists increased $94 \%$ and motor vehicle right-turn volumes increased by $15 \%$. Controlling for differences in volumes of bicycles and right-turning vehicles, fewer bicycle-motor vehicle conflicts are expected for an intersection with a bike box.

- Yielding: Our analysis of the three additional intersections for yielding behavior found an increase in the key behavior of right-turning cars yielding to cyclists at the treatment locations and a decrease at the control location. The increase is partially driven by additional interactions as a result of increased volumes; however, the increase in yielding is proportionally more than the volume increase.

- Perception of Safety: The surveys found that both motorists and cyclists perceived the intersections to be safer after the installation of the bike boxes. In particular, $42 \%$ of motorists who are not cyclists felt driving through the intersections was safer with the bike boxes (compared to $14 \%$ who felt it was more dangerous). Moreover, $77 \%$ of cyclists felt bicycling through the intersections was safer with the bike boxes (compared to $2 \%$ who felt it was more dangerous).

\section{Does the green color make a difference? The observational data did not detect significant differences between the green and no-color boxes, though the vast majority of surveyed motorists preferred the green boxes.}

- Although the timing of the bike box installations and the selection of intersections to receive color versus no color made a comparison difficult, some observations can be made about the effects of color on motorist and cyclist behavior. Motor vehicle encroachment in the bike lane prior to arriving at the intersection decreased for color locations, but not no-color locations. The color locations appear to encourage cyclists to stop ahead of the motor vehicle stop line. No significant difference in the frequency of conflicts was observed between color and no-color locations. In the survey, nearly $90 \%$ of motorists preferred the green bike box to the no-color bike box.

The study is not without limitations, which points to additional research needs. It is not clear how transferable the results are to other cities. Rates of bicycling in Portland are among the highest of any U.S. city, particularly in the core downtown area where the boxes were installed. The city has adopted many policies and programs and installed other infrastructure aimed to increase cycling, and the city's residents are generally favorable towards cycling. In addition, awareness of safety issues is high; $95 \%$ of the motorists surveyed remembered reading or hearing about a right-hook crash involving a cyclist. This context may have resulted in more positive results than other cities might experience. Other U.S. cities, including Austin, TX, are currently undertaking evaluations of bike box installations, which will help answer the question of transferability.

The limited time period of the study presents some limitations. A small number of conflicts were observed ( 20 before and 14 after). The negative-binomial safety comparison model may not be reliable at the upper range of the volumes because of the lack of data. Therefore, we do not maintain that the results are conclusive. These limitations point to the need for additional monitoring and evaluation over longer time periods and additional contexts. Thus, future work should seek to increase the sampling period for the before-and-after periods such that there are more observations of cycle and vehicle interactions. The use of automated video analysis would 
aid in large-scale data reduction. With a larger sample, we will be able to explore peak and offpeak safety performance. A longer evaluation period may also allow for the comparison of before-and-after crash data. While the lack of such data is typical of this type of study, it does limit the findings. We will need to revisit this evaluation over time when actual crash data are available. Moreover, as with any traffic control device, it may be relevant to explore changes in behavior after some time to identify whether compliance and yielding changes as the "newness" effect wears off.

At many locations in this study, the ability to interpret interactions between car, bicycle and pedestrians was limited by our field of view. In future evaluations, the placement of video cameras should be improved to provide synchronized views of the box location, the upstream leg and turning leg. The synchronized views will include signal-phase indications (vehicle and pedestrian) such that conflicts and issues associated with arrivals on red or during the green phase can be explored.

Finally, the small sample size of the non-color locations makes conclusions about the effects of color less clear. The question of colored markings could be further explored with a selection of better matched locations. 


\section{REFERENCES}

Allen, D., S. Bygrave, and H. Harper. 2005. Behavior at Cycle Advanced Stop Lines Report No. PPR240. London, UK: Transport for London, London Road Safety Unit.

Atkins Services, 2005. Advanced Stop Line Variations, Research Study Report No. 5031271. London: Transport for London.

Bartlett, Wade, Albert Baxter, Ed Livesay, Bruno Schmidt, Terry Stanard, and William Wright. 2006. Comparison of Drag-Sled and Skidding-Vehicle Drag Factors on Dry Roadways. Society of Automotive Engineers, Inc., Paper 2006-01-1398, Warrendale PA.

Cameron, C.A., and P.K. Trivedi. 1998. Regression analysis of count data. Cambridge University Press.

City of Portland, Office of Transportation, 2004. "Pedestrian and Bicycle Enhanced Enforcement Project: Opportunity Analysis", Portland, OR, 2004. http://www.portlandonline.com/transportation/index.cfm?a=99325\&c=34811. Accessed September 8, 2010.

City of Portland, Office of Transportation, 2007. "Improving Bicycle Safety in Portland," October 26, 2007. http://www.portlandonline.com/transportation/index.cfm?a=185776\&c=34811 Accessed September 8. 2010.

Elvik, R., and A.B. Mysen. 1999. Incomplete Accident Reporting: Meta-Analysis of Studies Made in 13 Countries. Transportation Research Record 1665: 133-140.

Garder, P., L. Leden, and U. Pulkkinen. 1998. Measuring the Safety Effect of Raised Bicycle Crossings Using a New Research Methodology. Transportation Research Record 1636: 64-70.

Hunter, W. W.. 2000. Evaluation of Innovative Bike-Box Application in Eugene, Oregon. Transportation Research Record 1705: 99-106.

Hunter, W. W., D. L. Harkey, J.R. Stewart, and M.L. Birk. 2000. Evaluation of Blue Bike-Lane Treatment in Portland, Oregon. Transportation Research Record 1705: 107-115.

Hunter, William W., Wayne E. Pein, and Jane C. Stutts. Bicycle-Motor Vehicle Crash Types: The Early 1990s. Transportation Research Record 1502: 65-74.

Jensen, S. U.. 2008. Safety effects of blue cycle crossings: A before-after study. Accident Analysis \& Prevention 40(2): 742-750. 
Koorey G.F., Mangundu E. 2010. Effects on Motor Vehicle Behavior of Color and Width of Bicycle Facilities at Signalized Intersections. Paper presented at the 89th Transportation Research Board (TRB) Annual Meeting, January 10-14, 2010, in Washington DC.

Lord, D., and F. Mannering. 2010. The statistical analysis of crash-frequency data: A review and assessment of methodological alternatives. Transportation Research Part A: Policy and Practice 44(5): 291-305. doi:10.1016/j.tra.2010.02.001.

National Cooperative Highway Research Program (2008). NCHRP Report 500: Guidance for Implementation of the AASHTO Strategic Highway Safety Plan: A Guide for Reducing Collisions Involving Bicycles (Vol. 18). Washington, D.C.: Transportation Research Board.

Newman, A.. 2002. Marking of Advanced Cycle Lanes and Advanced Stop Boxes at Signalized Intersections, the Report. Christchurch, NZ: Christchurch City Council, City Streets Unit.

Portland Office of Transportation. 2004. Portland Safe Communities: Pedestrian and Bicycle Enhanced Enforcement Project. Portland, OR: City of Portland Office of Transportation.

Rodgers, A.. 2005. A23 \& A202 ASL Before \& After Study Report No. T40900; 5085R/AB CD1/RF. Hertfordshire, UK: Transport for London, Cycling Centre of Excellence.

Sadek, A. W., A.S. Dickason, and J. Kaplan. 2007. Effectiveness of Green, High-Visibility Bike Lane and Crossing Treatment. Paper presented at the Transportation Research Board 86th Annual Meeting, January 21-25, 2007, in Washington D.C..

Stutts, J. C., and W.W. Hunter. 1999. Motor Vehicle and Roadway Factors in Pedestrian and Bicyclist Injuries: An Examination Based on Emergency Department Data. Accident Analysis and Prevention 31(5): 505-514.

United States Department of Transportation. 2010. Policy Statement on Bicycle and Pedestrian Accommodation Regulations and Recommendations, Signed on March 11, 2010 and announced March 15, 2010. http://www.dot.gov/affairs/2010/bicycle-ped.html. Accessed September 8, 2010

Wall, G. T., D.G. Davies, and M. Crabtree. 2003. Capacity implications of advanced stop lines for cyclists. UK: Transport Research Laboratory. 


\section{APPENDIX A}

\section{A. INTERSECTION PLANS AND PHOTOGRAPHS}




\section{BIKE BOX PLANS AND PHOTOGRAPHS}

The plans and photographs below illustrate the intersections examined in this study. Control Intersections are included following the bike box intersections.

\section{NW Everett Street at NW $16^{\text {th }}$ Avenue (Green Bike Box)}

Approach with Bike Box: 2 through lanes, one-way
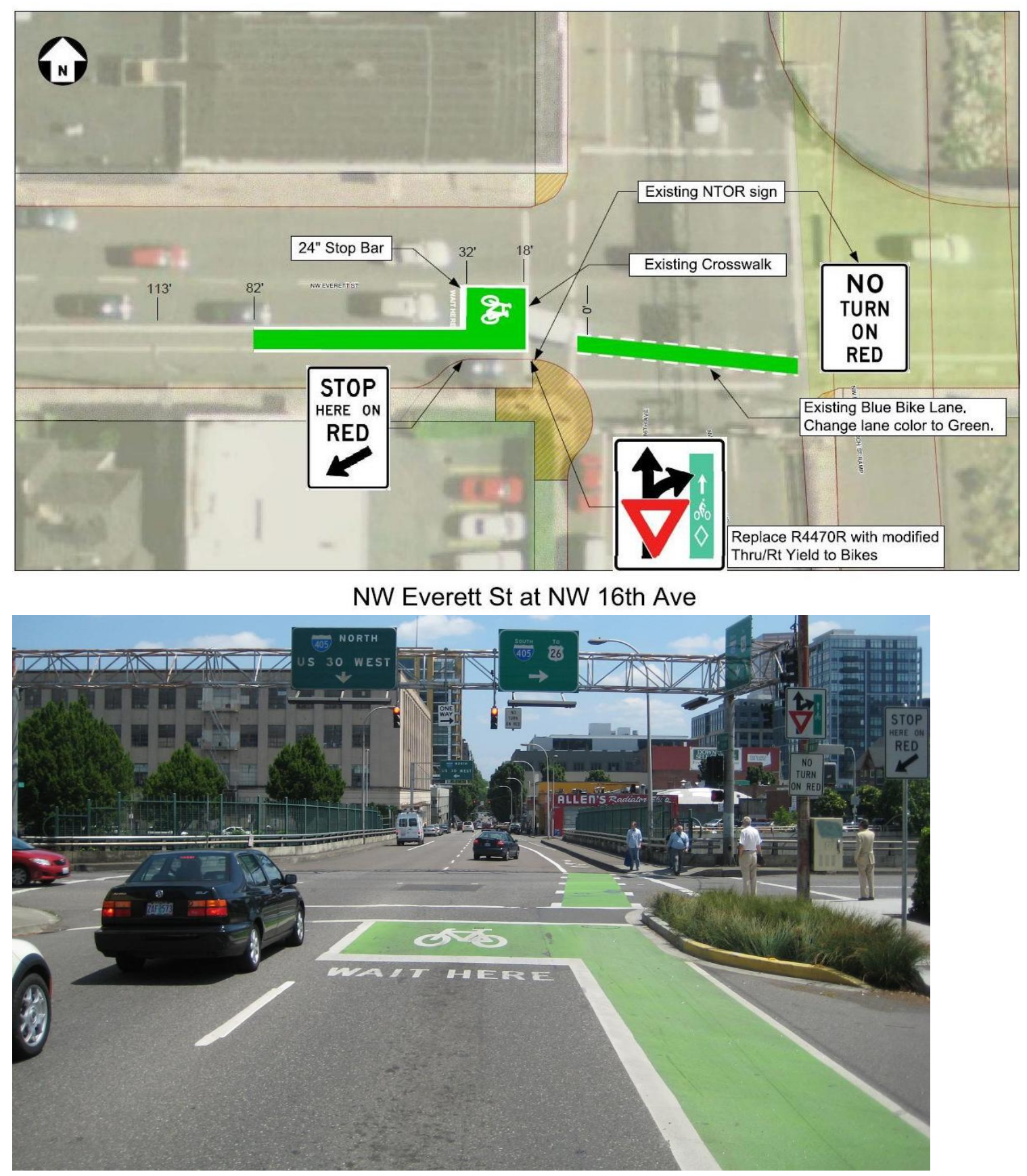
SE Hawthorne Boulevard at SE $11^{\text {th }}$ Avenue (Green Bike Box)

Approach with Bike Box: 3 through lanes, one-way
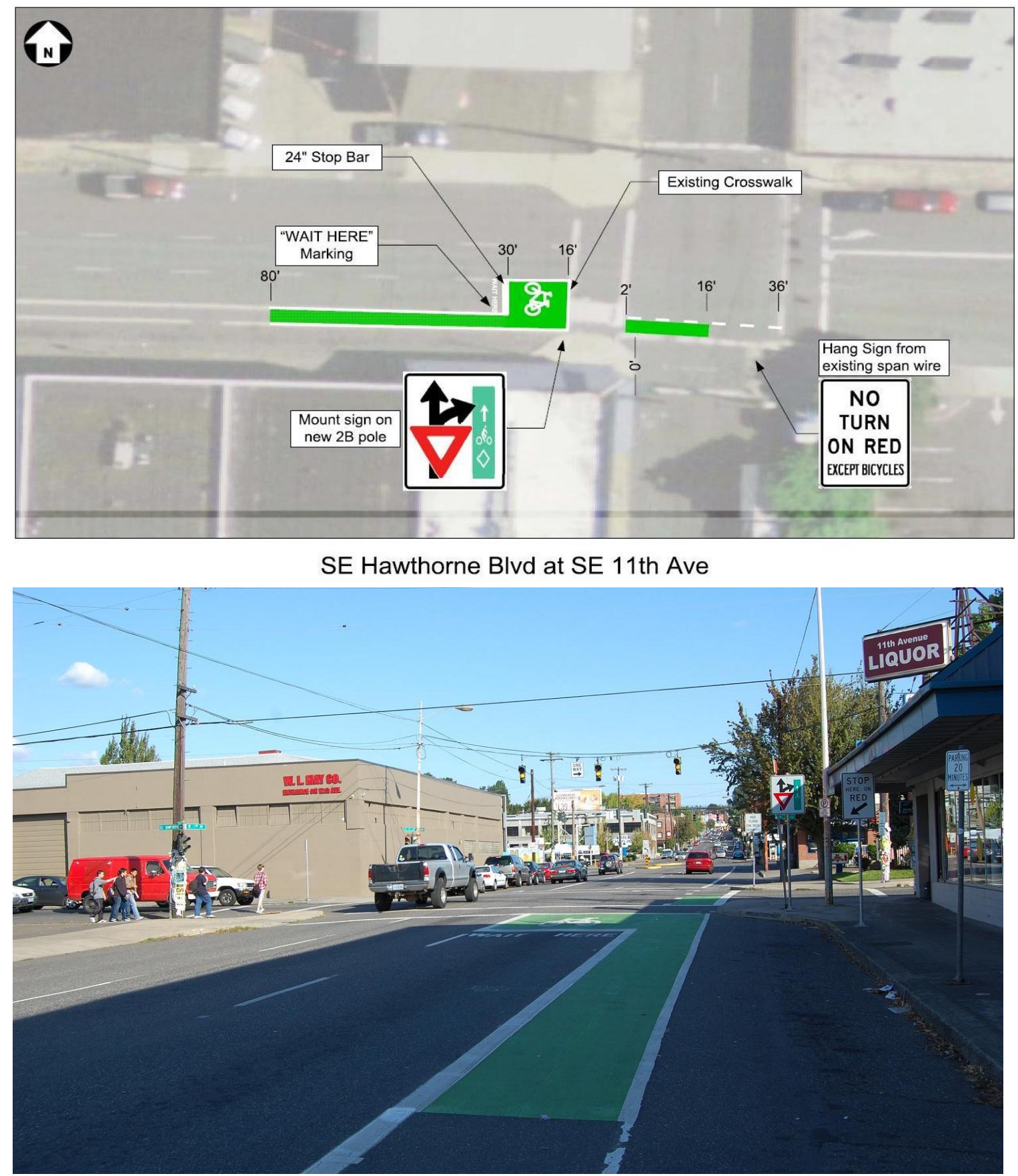
SE Hawthorne Boulevard at SE $7^{\text {th }}$ Avenue (Green Bike Box)

Approach with Bike Box: 3 through lanes, one-way

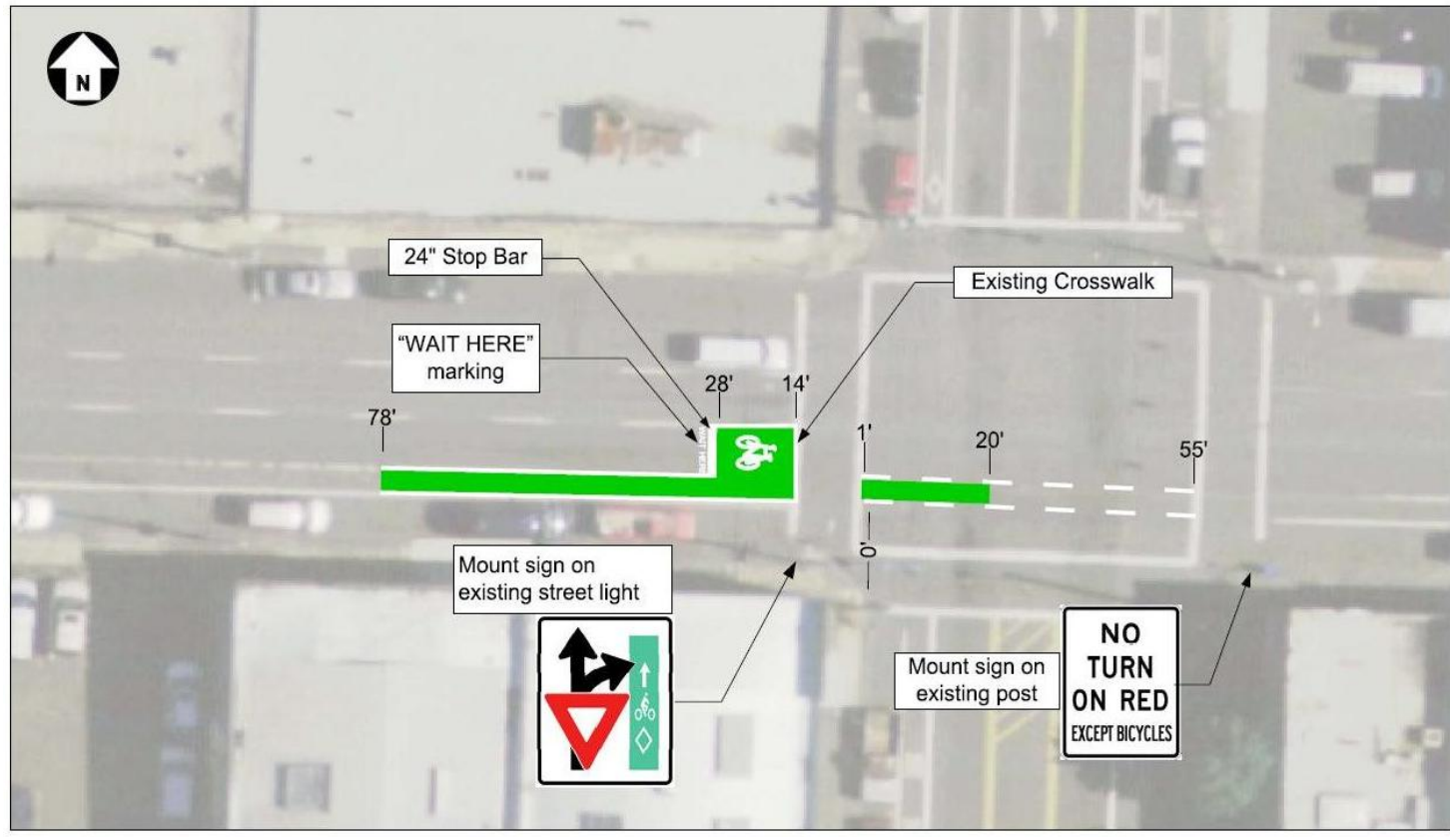

SE Hawthorne Blvd at SE 7th Ave

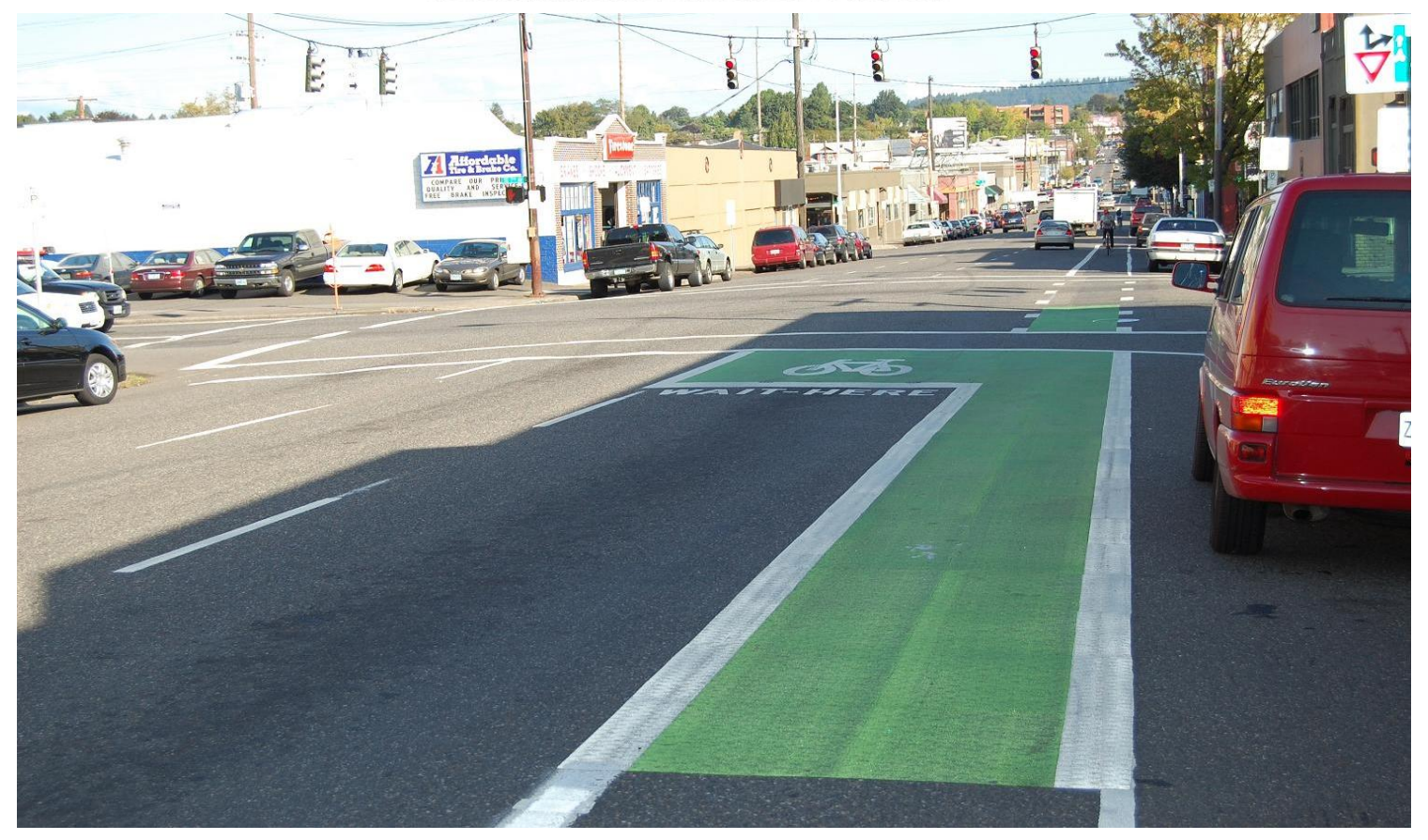




\section{SW Madison Street at SW $3^{\text {rd }}$ Avenue (Green Bike Box)}

Approach with Bike Box: 2 through lanes, one-way

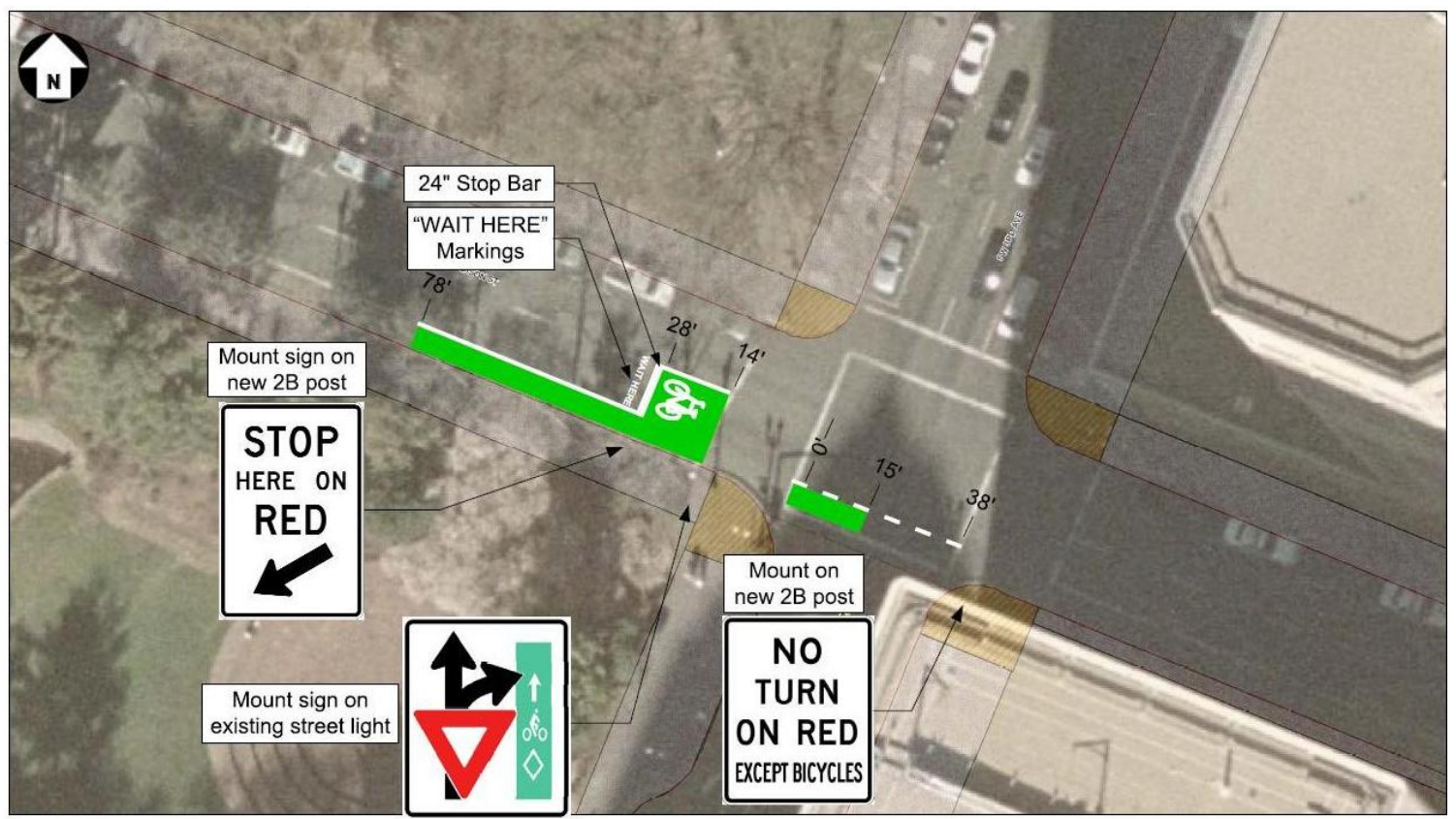

SW Madison St at SW 3rd Ave

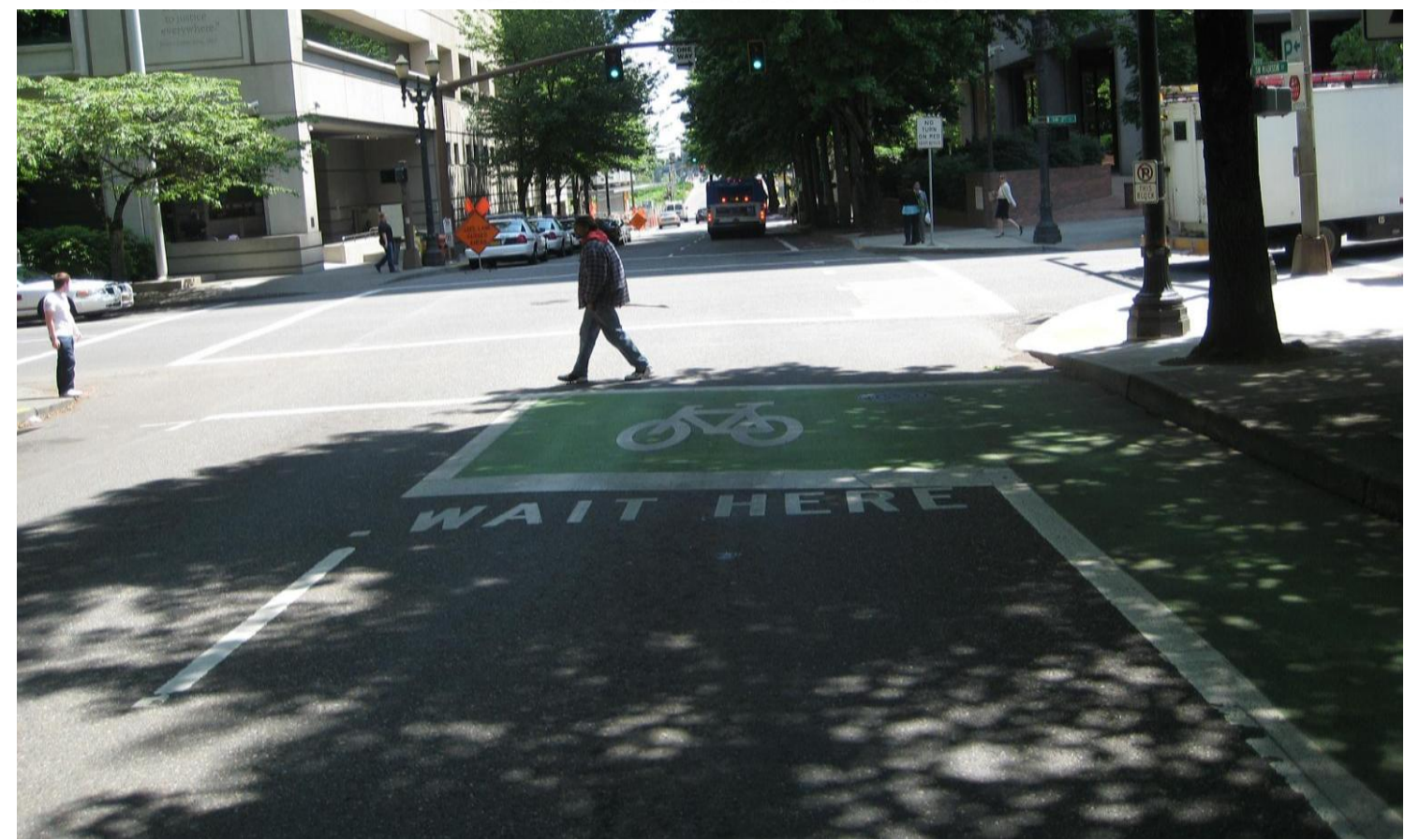




\section{SW $6^{\text {th }}$ Avenue at SW Broadway (Green Bike Box)}

Approach with Bike Box: 3 approaching through lanes, two-way (4 lanes total)

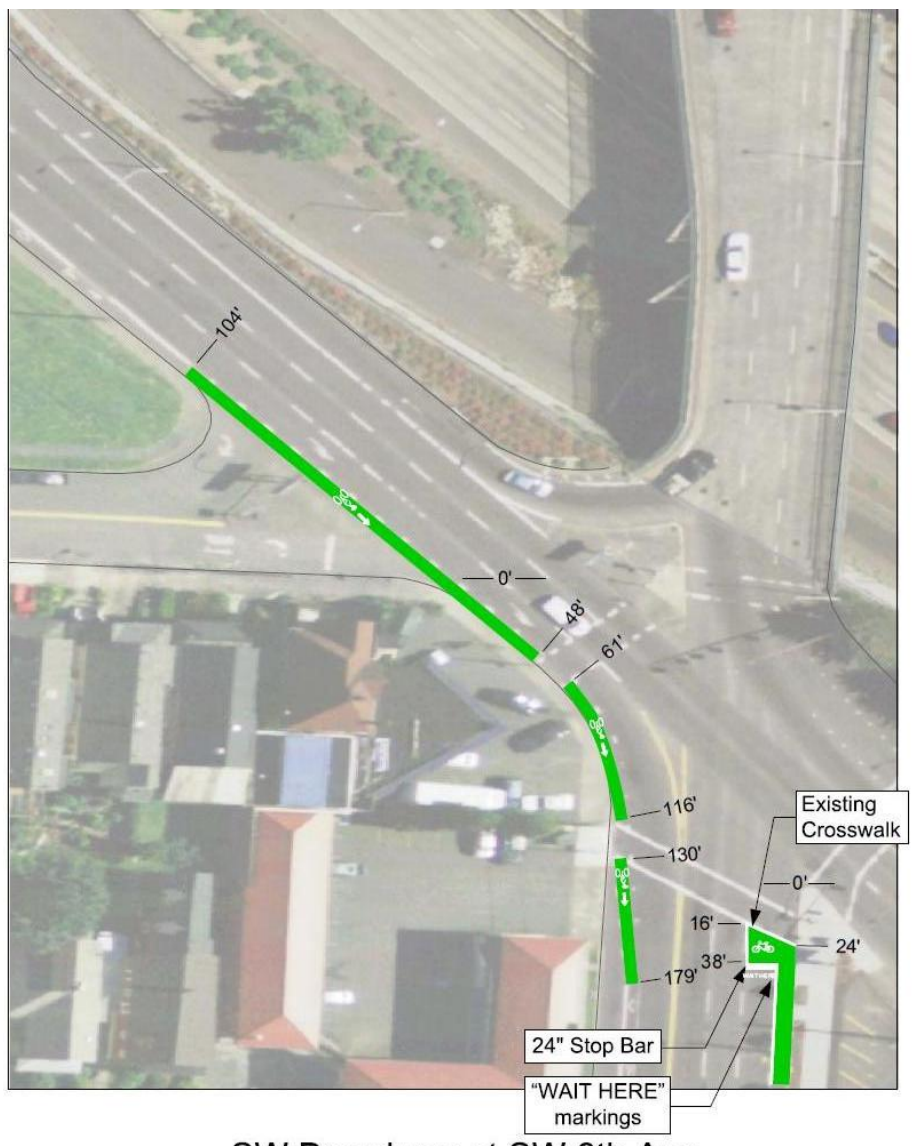

SW Broadway at SW 6th Ave

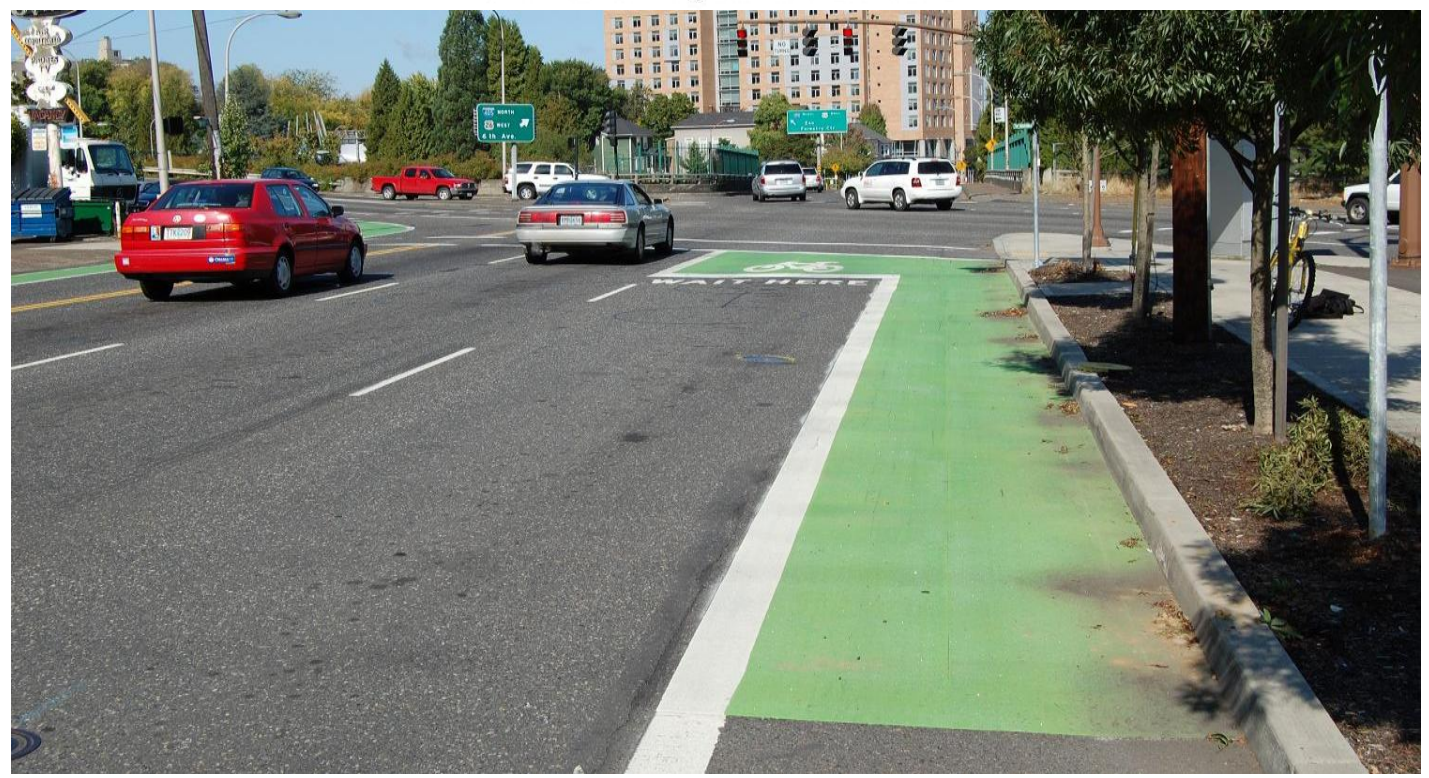




\section{SW Broadway \& SW Taylor Street (Green Bike Box)}

Approach with Bike Box: 3 through lanes, one-way

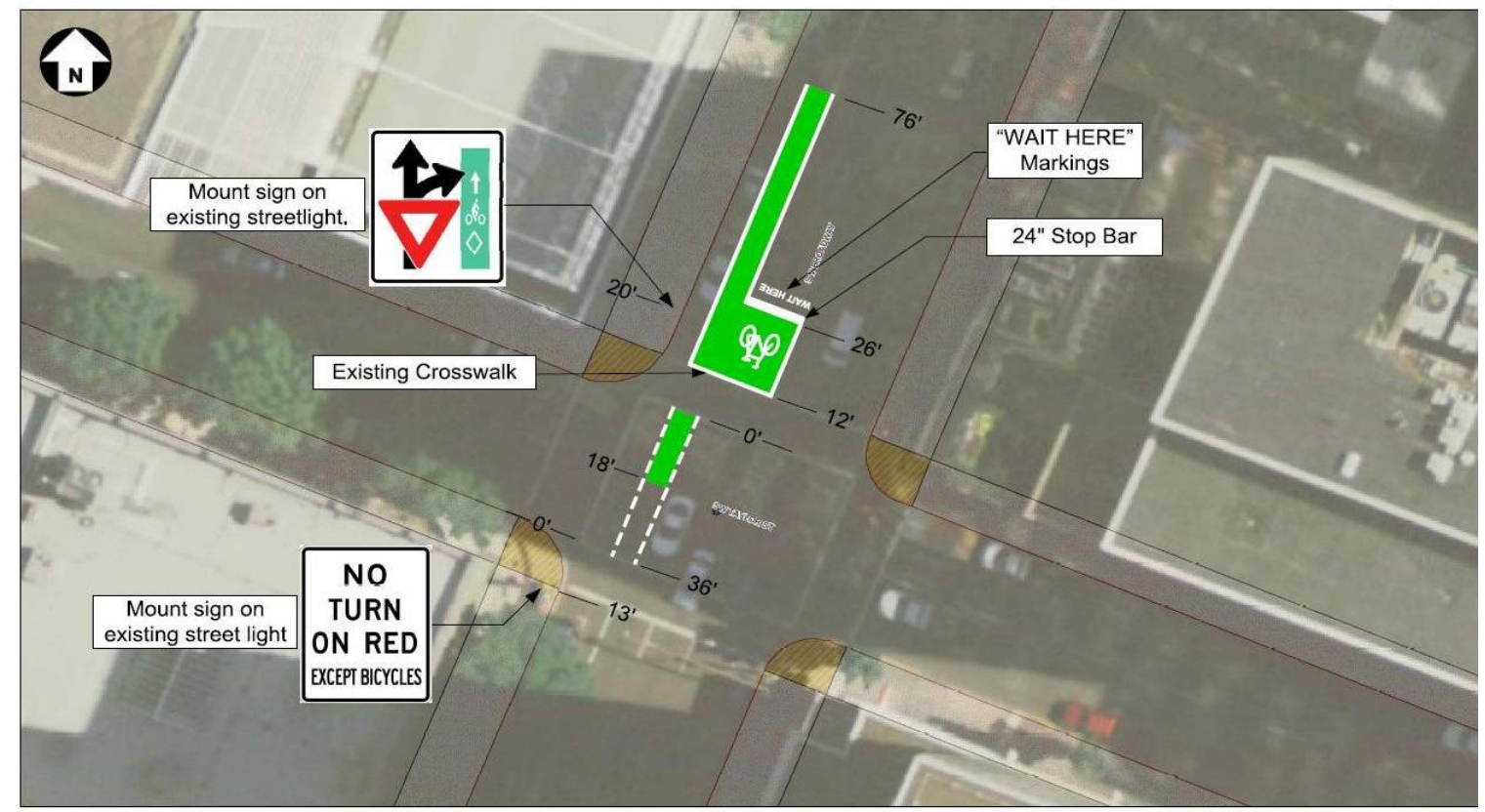

SW Broadway at SW Taylor St

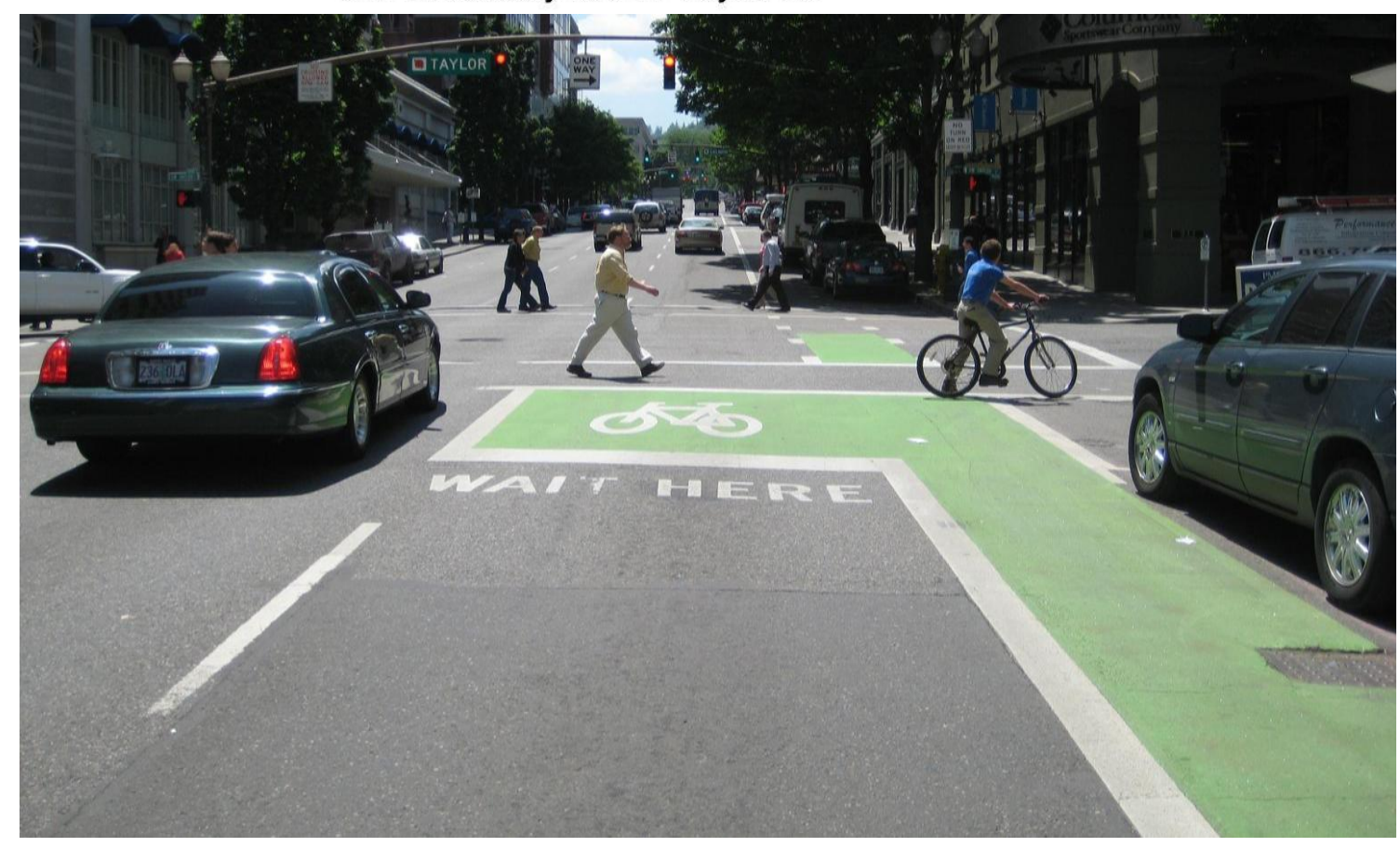




\section{SW $14^{\text {th }}$ Avenue at W Burnside (Green Bike Box)}

Approach with Bike Box: 3 through lanes, one-way

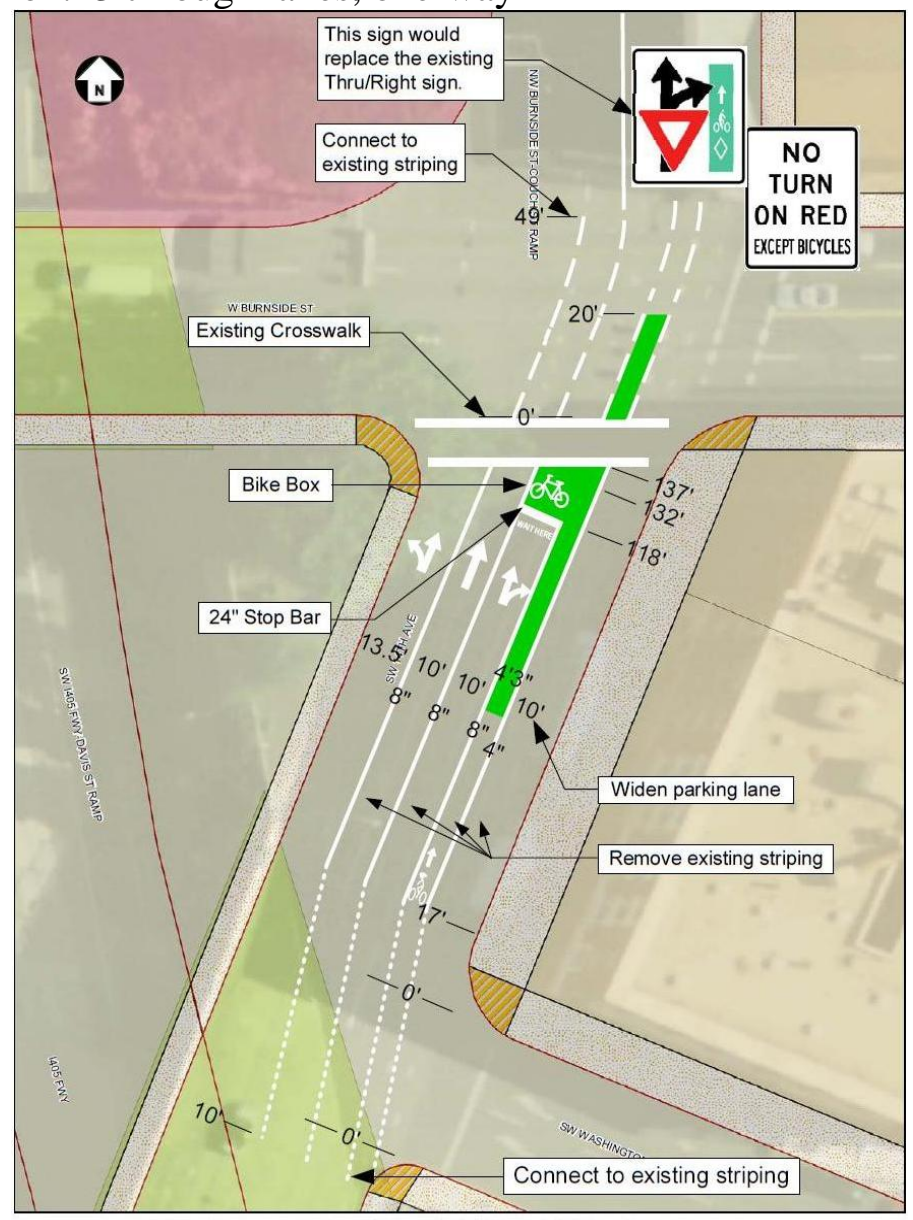

W Burnside St at SW 14th Avenue

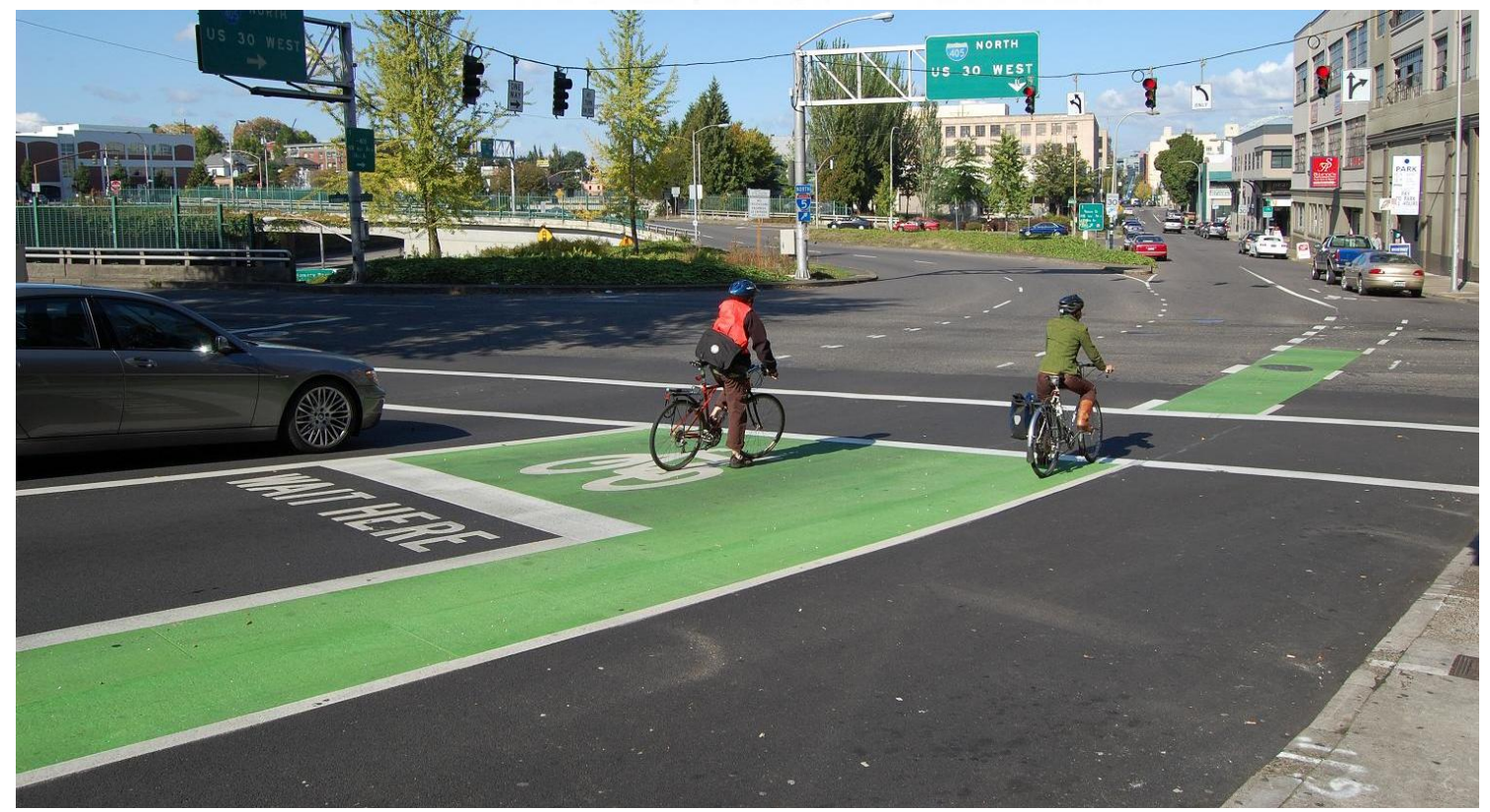


NW Broadway at NW Hoyt Street (No Color Bike Box)

Approach with Bike Box: Two approaching through lanes, two-way (4 lanes total)

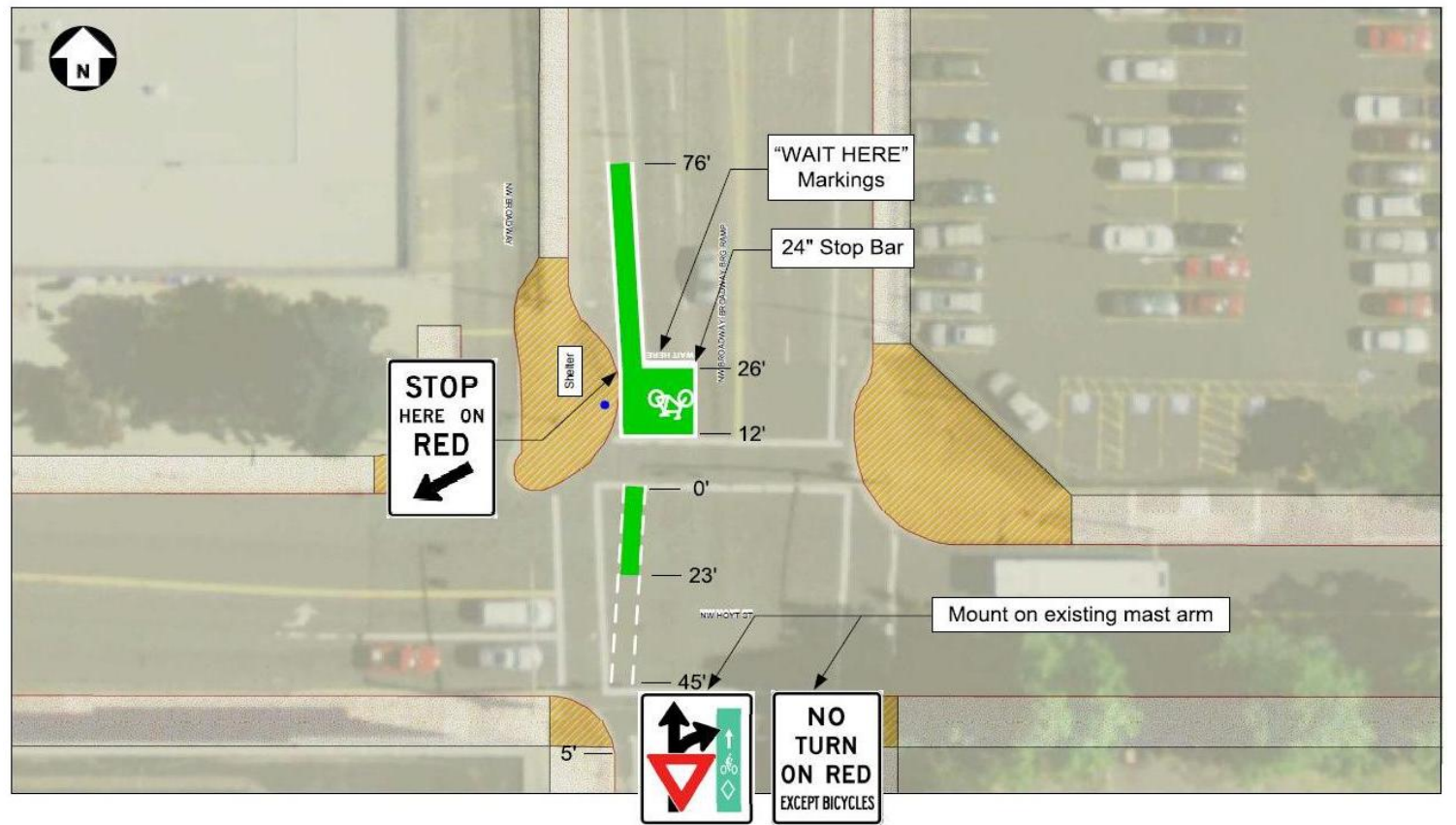

NW Broadway at NW Hoyt St

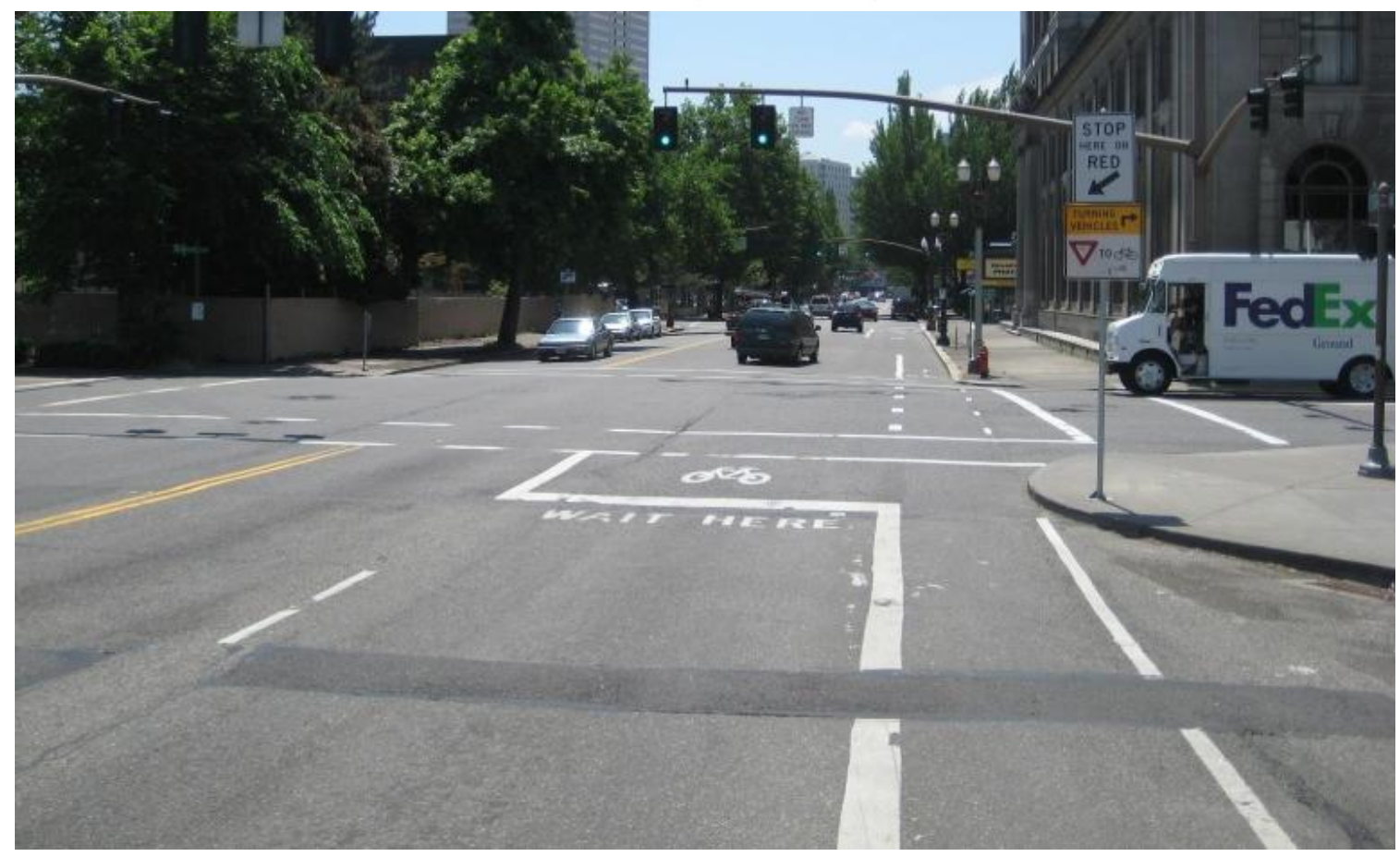

*Note: Although the plans indicate the installation has color, the City of Portland did not add color at this location, as seen in the photograph. 


\section{SW Terwilliger Boulevard at SW Taylors Ferry Road, Northbound (No Color Bike Box)}

Approach with Bike Box: 2 approaching lanes (1 through, 1 left-turn), two-way (4 lanes total)

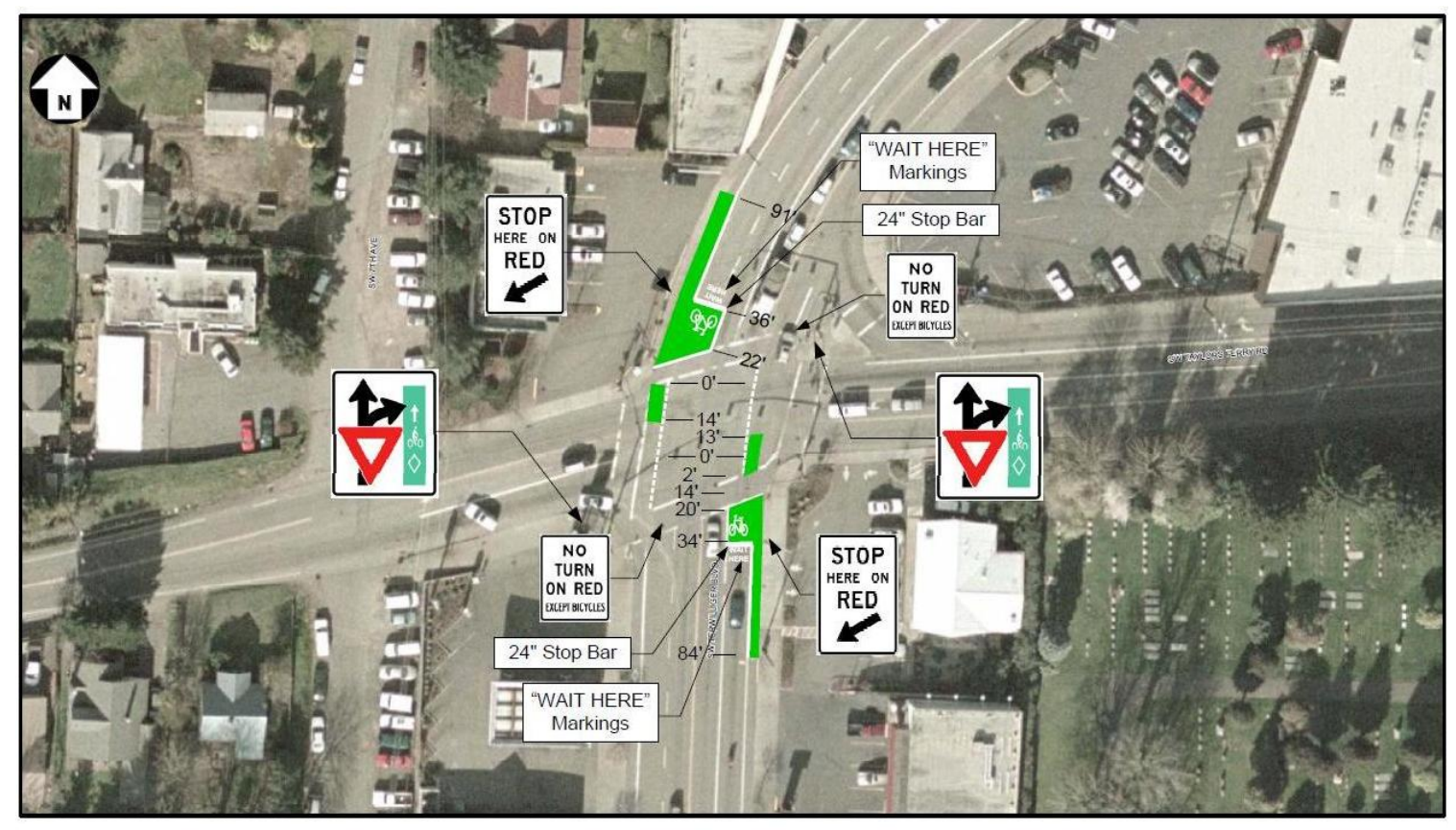

SW Terwilliger Blvd at SW Taylors Ferry Rd

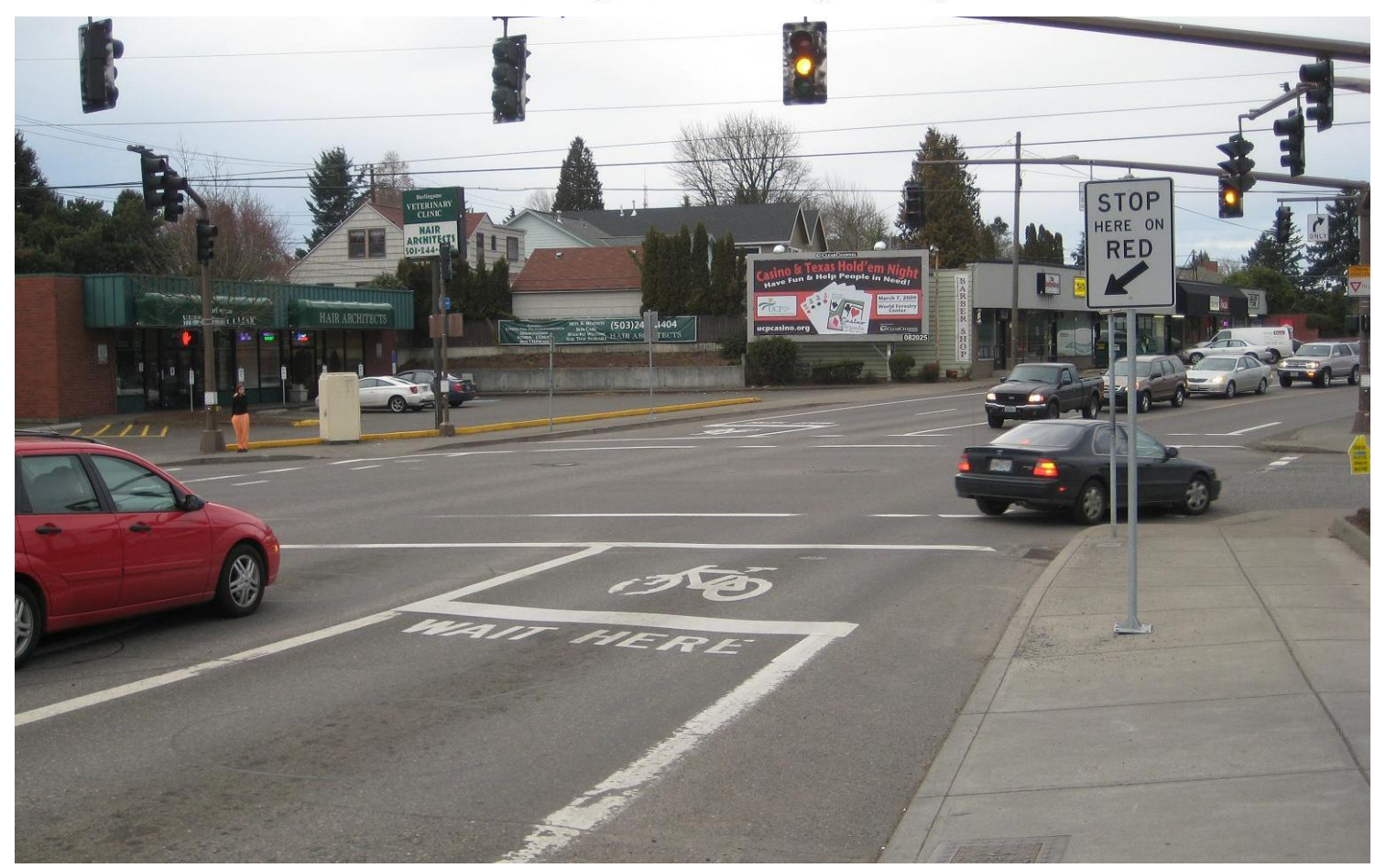

*Note: Although the plans indicate the installation has color, the City of Portland did not add color at this location, as seen in the photograph. 


\section{SW Terwilliger Boulevard at SW Taylors Ferry Road, Southbound (No Color Bike Box)}

Approach with Bike Box: 3 approaching lanes (2 through, 1 left-turn), two-way (4 lane total)

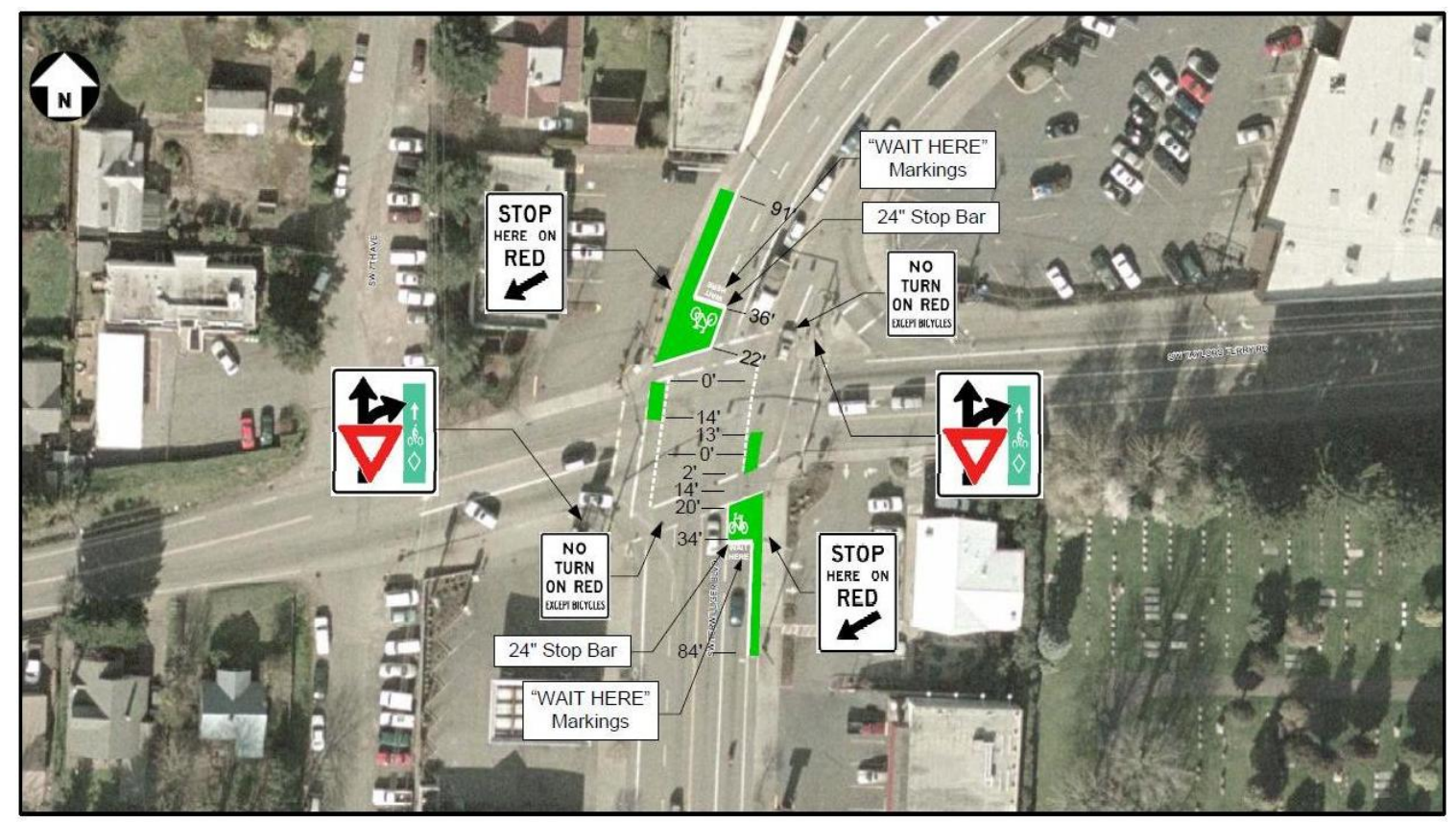

SW Terwilliger Blvd at SW Taylors Ferry Rd

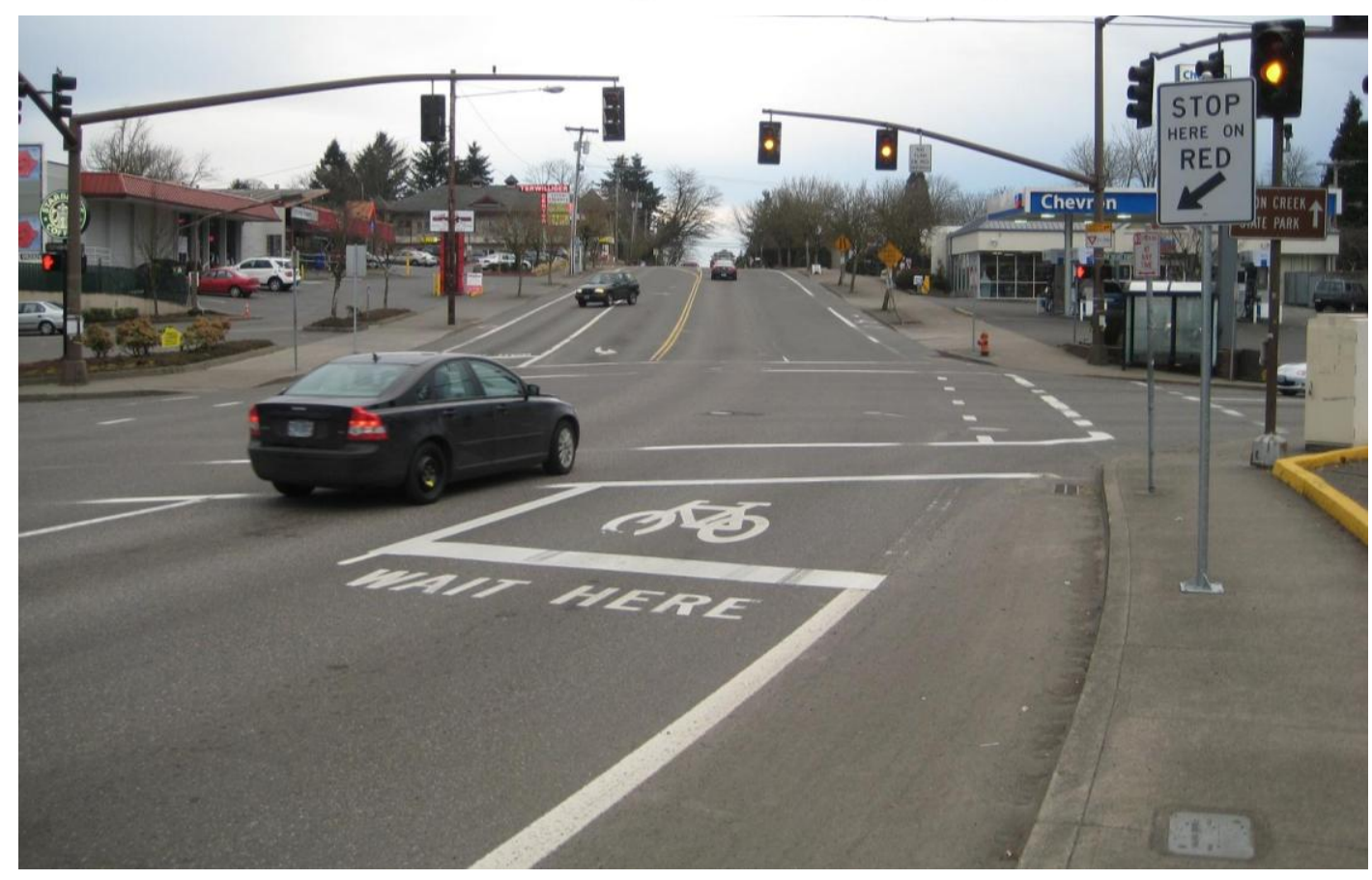

*Note: Although the plans indicate the installation has color, the City of Portland did not add color at this location, as seen in the photograph. 
NE Weidler Street at NE $16^{\text {th }}$ Avenue (Control Intersection)

Approach: 3 lanes ( 2 through, 1 left-turn), one-way
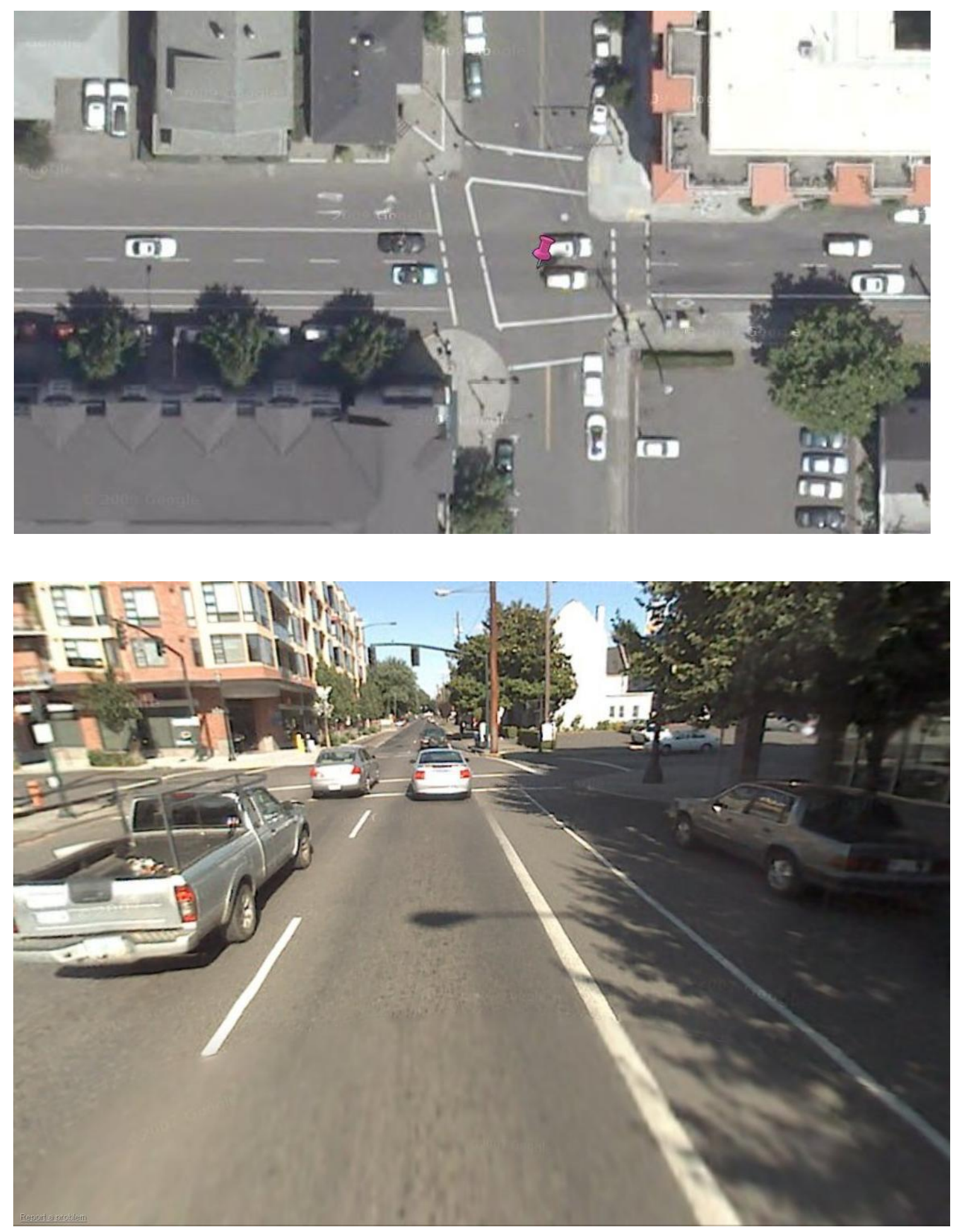
NE Weidler Street at NE $7^{\text {th }}$ Avenue (Control Intersection)

Approach: 3 through lanes, one-way
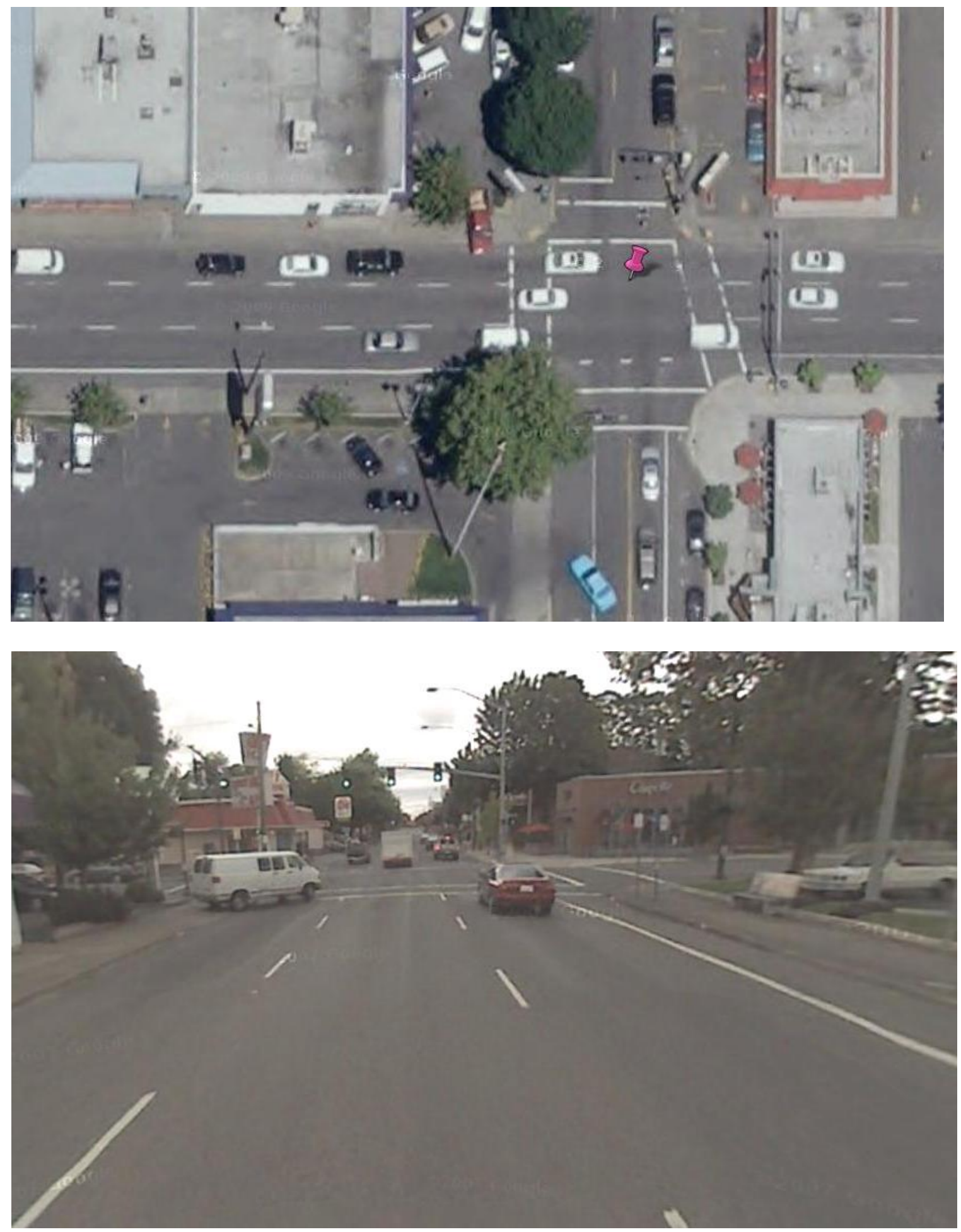


\section{PHOTOGRAPHS OF BIKE BOX WEAR}




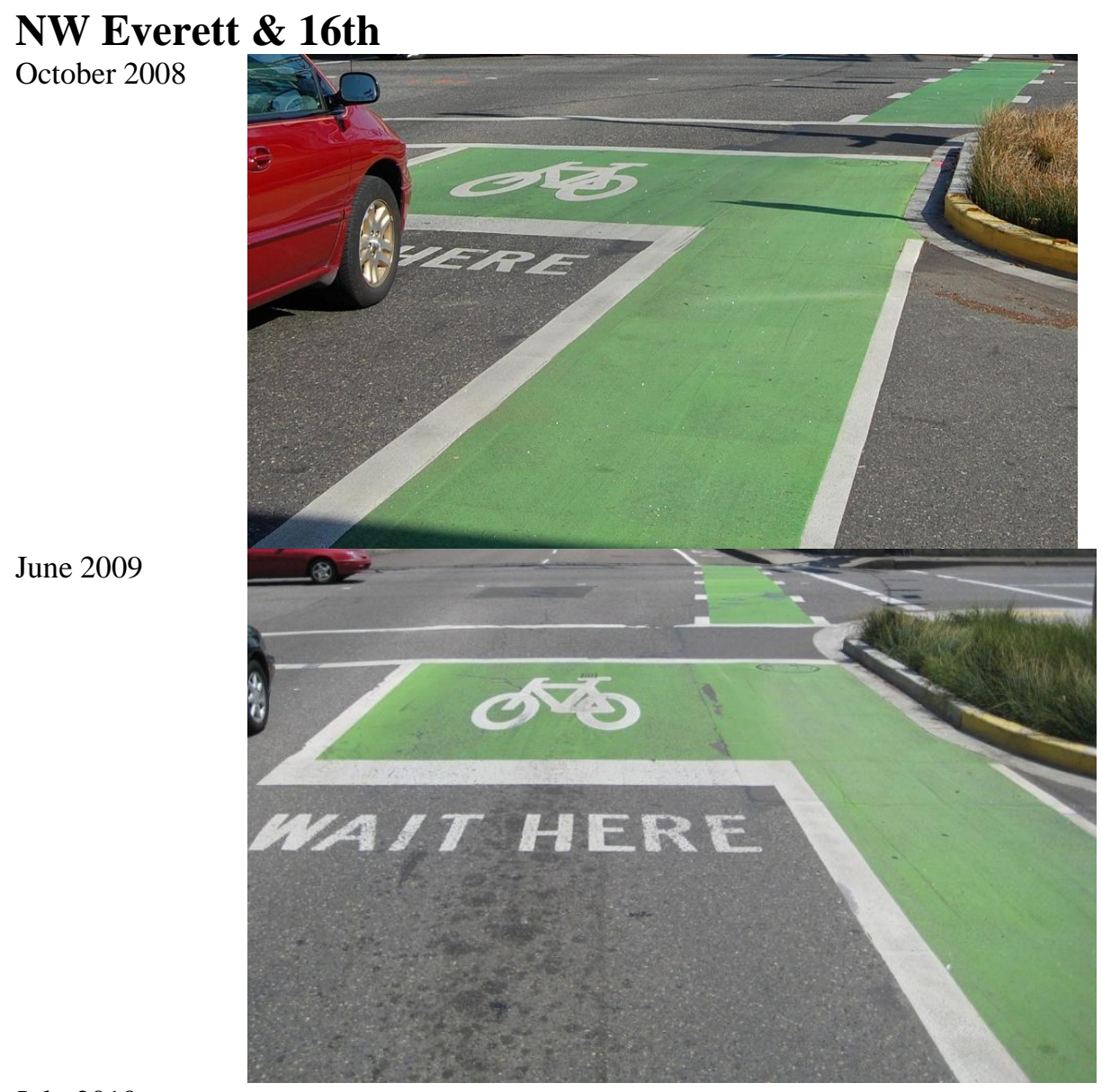

July 2010
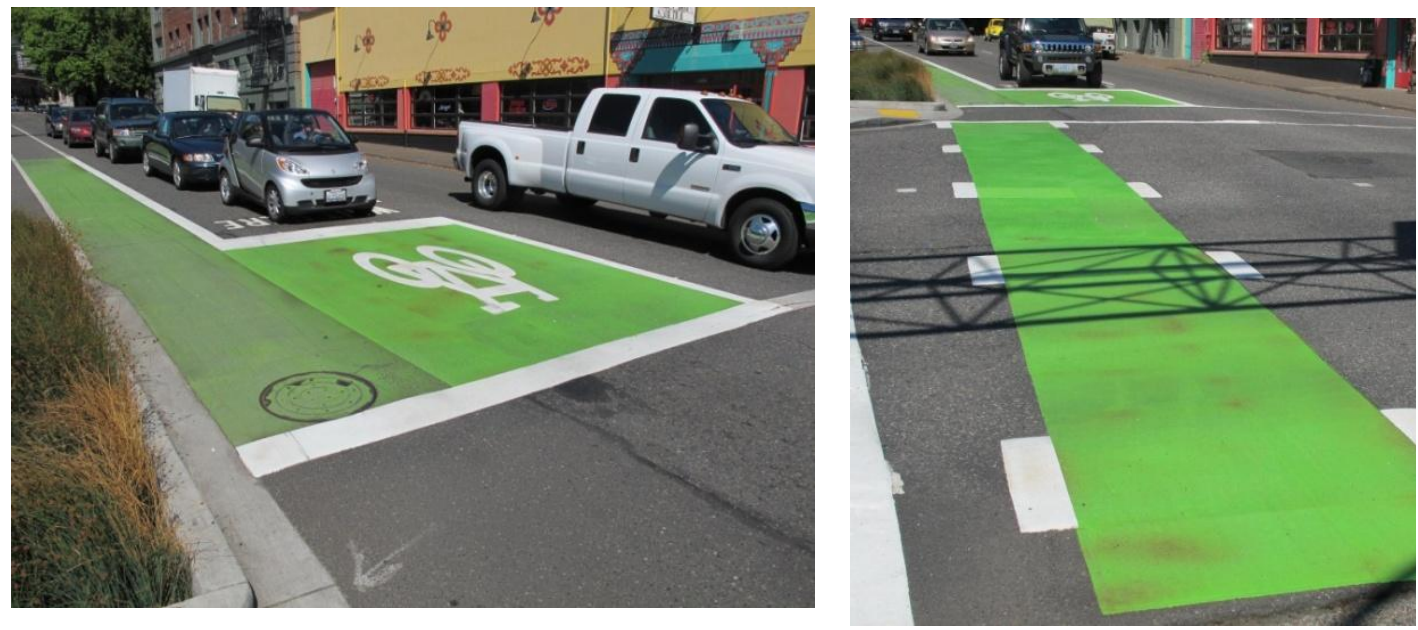

Daily Traffic Data from City of Portland:

\begin{tabular}{|c|c|c|c|c|c|c|c|}
\hline Location & Date & Type & Total & East & West & North & South \\
\hline NW 16th Ave, N/NW Everett St & 18-Jun-01 & Vol & 17798 & & & & 17798 \\
\hline NW Everett St, W/NW 16th Ave & 4-Aug-99 & Vol & 14739 & 14739 & & & \\
\hline
\end{tabular}




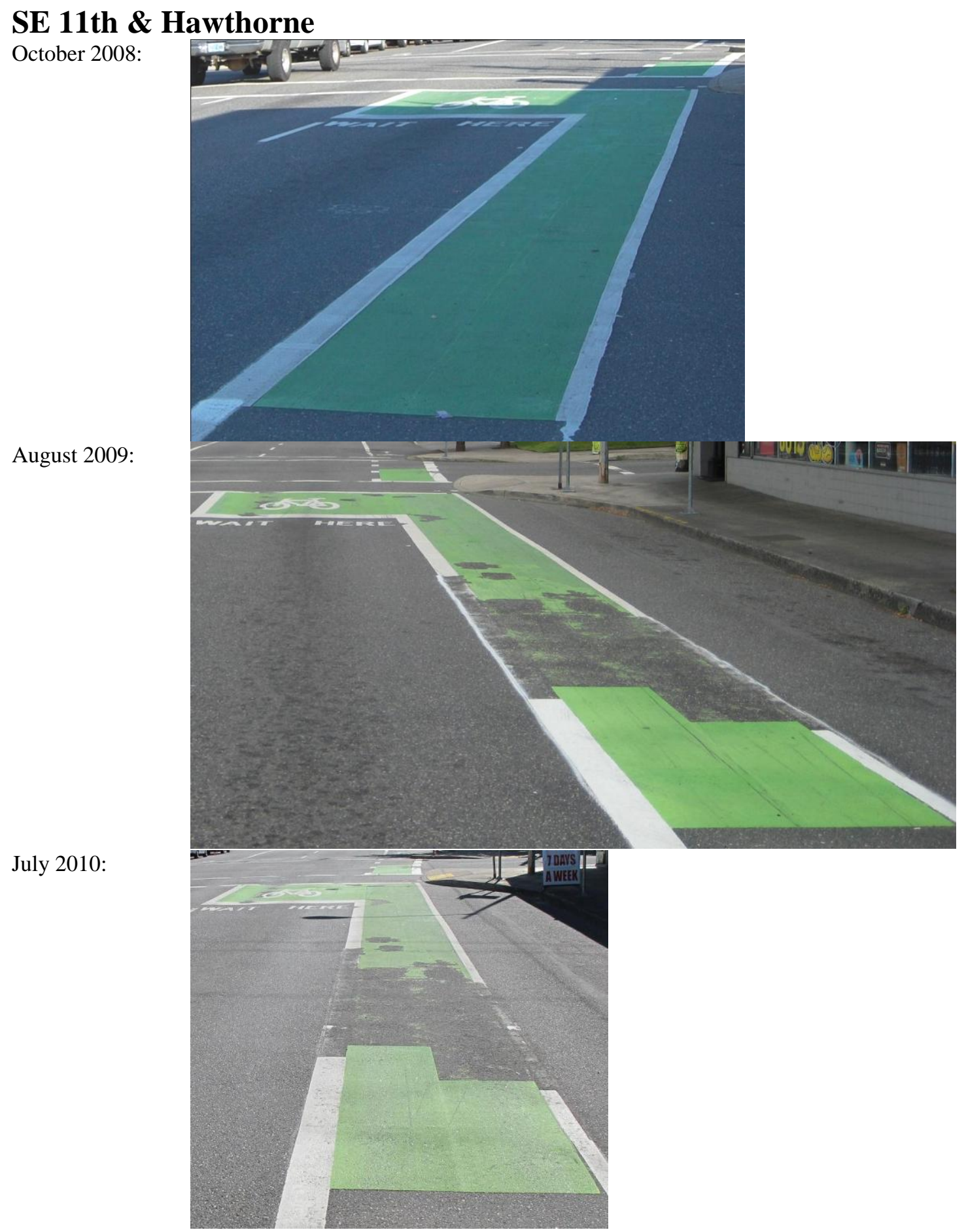

Daily Traffic Data from City of Portland:

\begin{tabular}{|c|c|c|r|c|c|c|c|}
\hline Location & Date & Type & Total & East & West & North & South \\
\hline SE Hawthorne Blv, W/SE 11th Ave & 25-Sep-00 & Vol & 11548 & 11548 & & & \\
\hline SE 11th Ave, N/SE Hawthorne Blv & 25-Sep-00 & Vol & 8666 & & & & 8666 \\
\hline
\end{tabular}

\section{SE 7th \& Hawthorne}




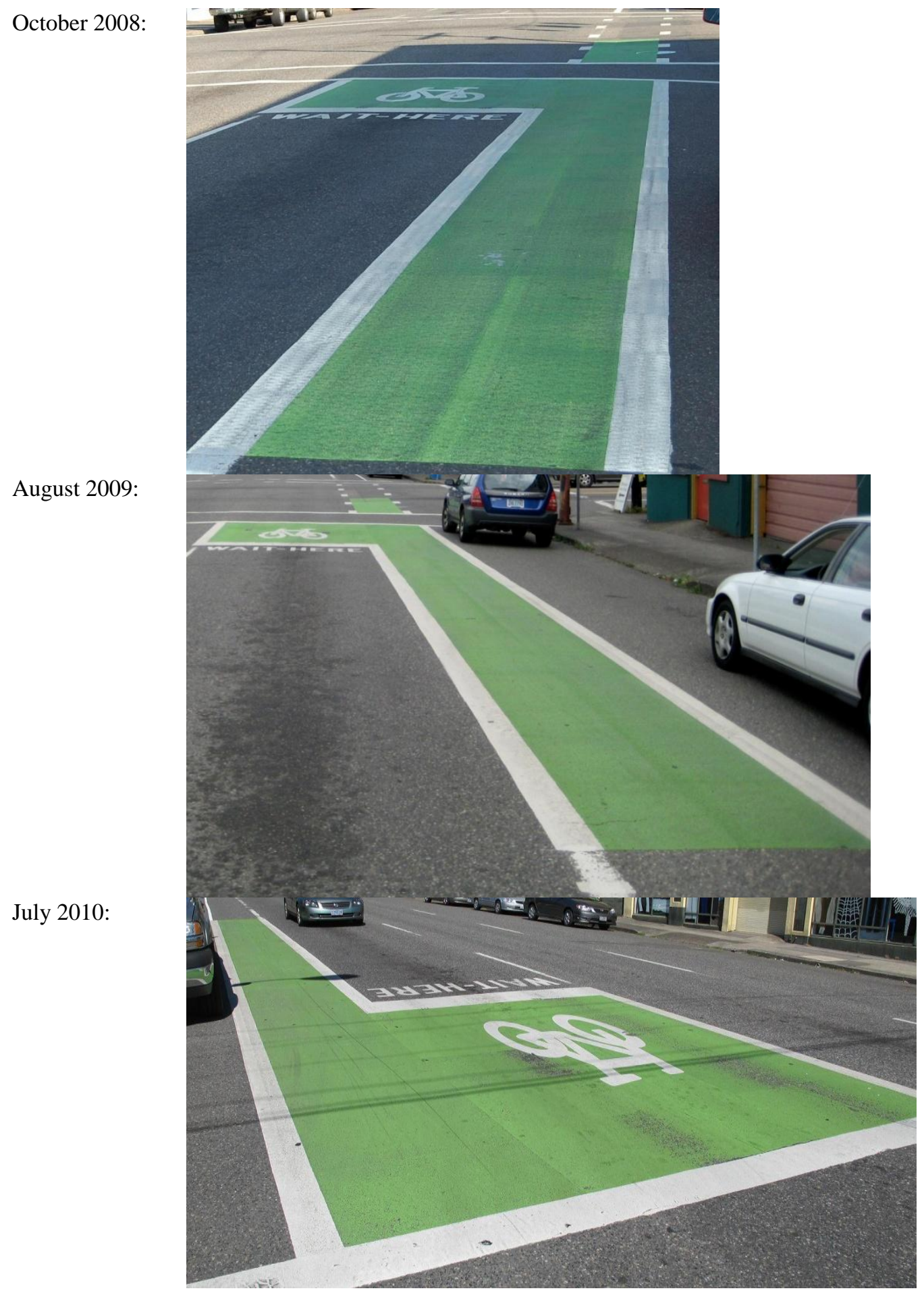

Daily Traffic Data from City of Portland:

\begin{tabular}{|c|c|c|c|c|c|r|r|}
\hline Location & Date & Type & Total & East & West & North & South \\
\hline SE 7th Ave ent SE Hawthorne Blvd. & 25-Sep-00 & Vol & 8491 & & & 3538 & 4953 \\
\hline SE Hawthorne Blv, W/SE 7th Ave & 25-Sep-00 & Vol & 10398 & 10398 & & & \\
\hline
\end{tabular}

SW 3rd \& Madison 
October 2008:

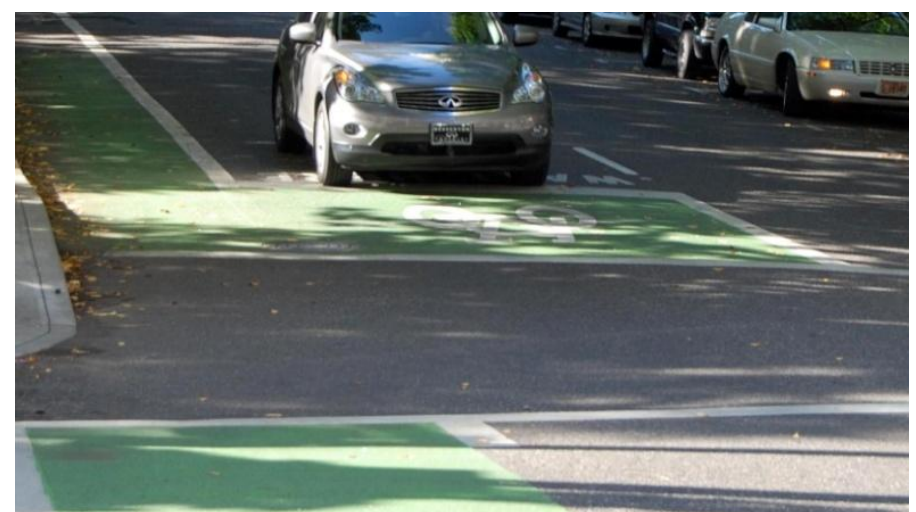

February 2009:

July 2010:

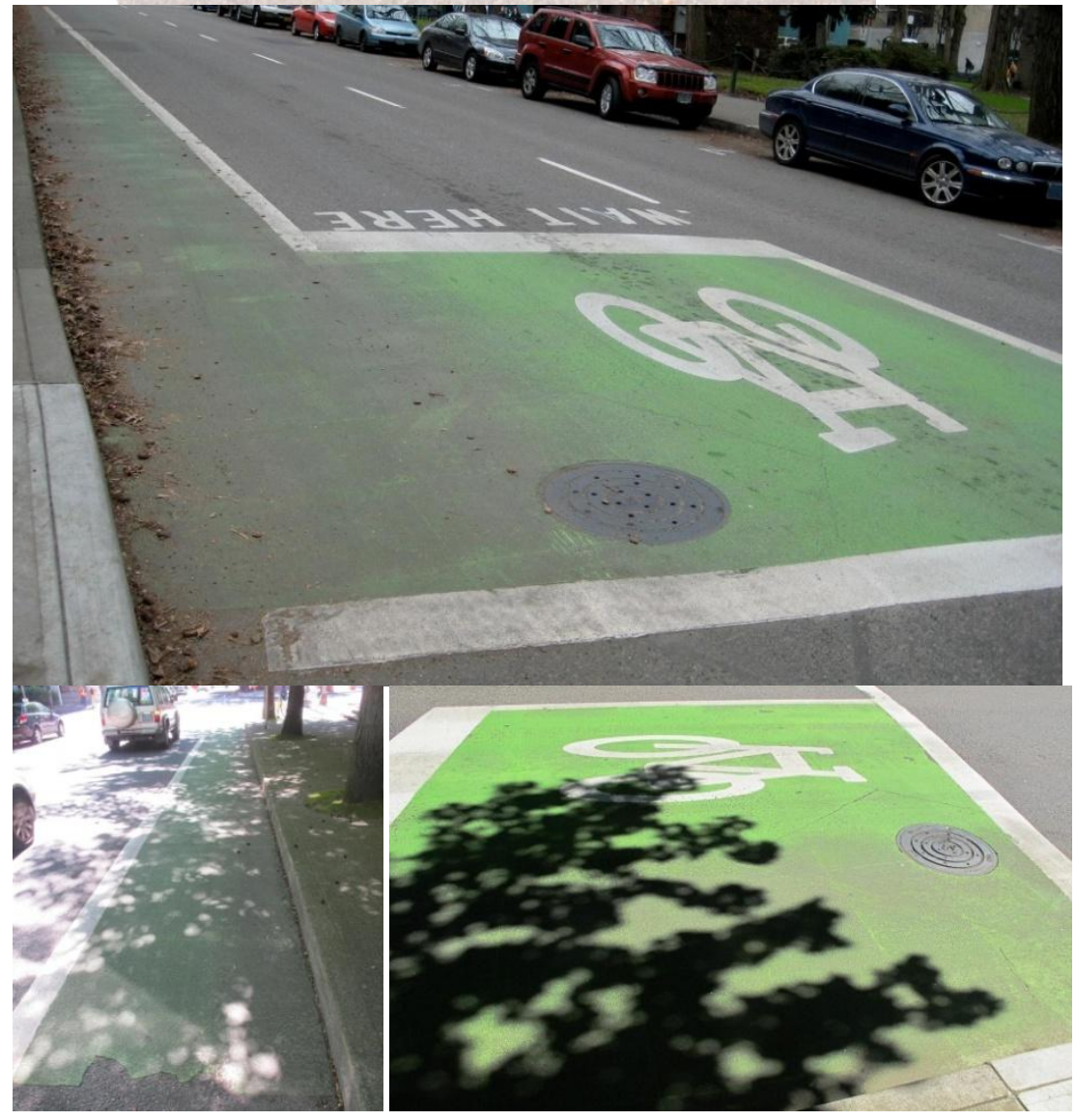




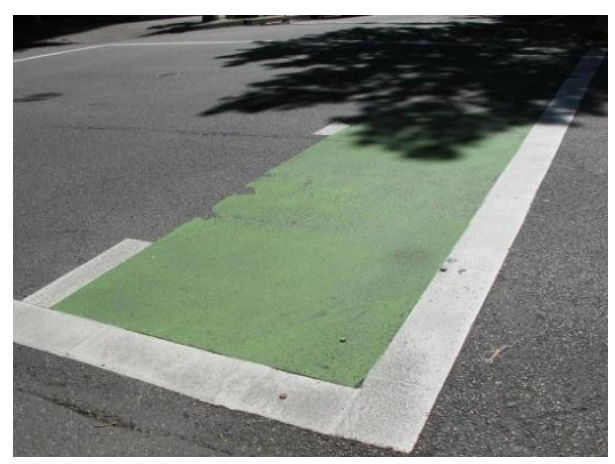

Daily Traffic Data from City of Portland:

\begin{tabular}{|c|c|c|c|c|c|c|c|}
\hline Location & Date & Type & Total & East & West & North & South \\
\hline SW Madison St, W/SW 3rd Ave & 5-Sep-00 & Vol & 6858 & 6858 & & & \\
\hline SW 3rd Ave, N/SW Madison St & 5-Sep-00 & Vol & 11713 & & & & 11713 \\
\hline
\end{tabular}




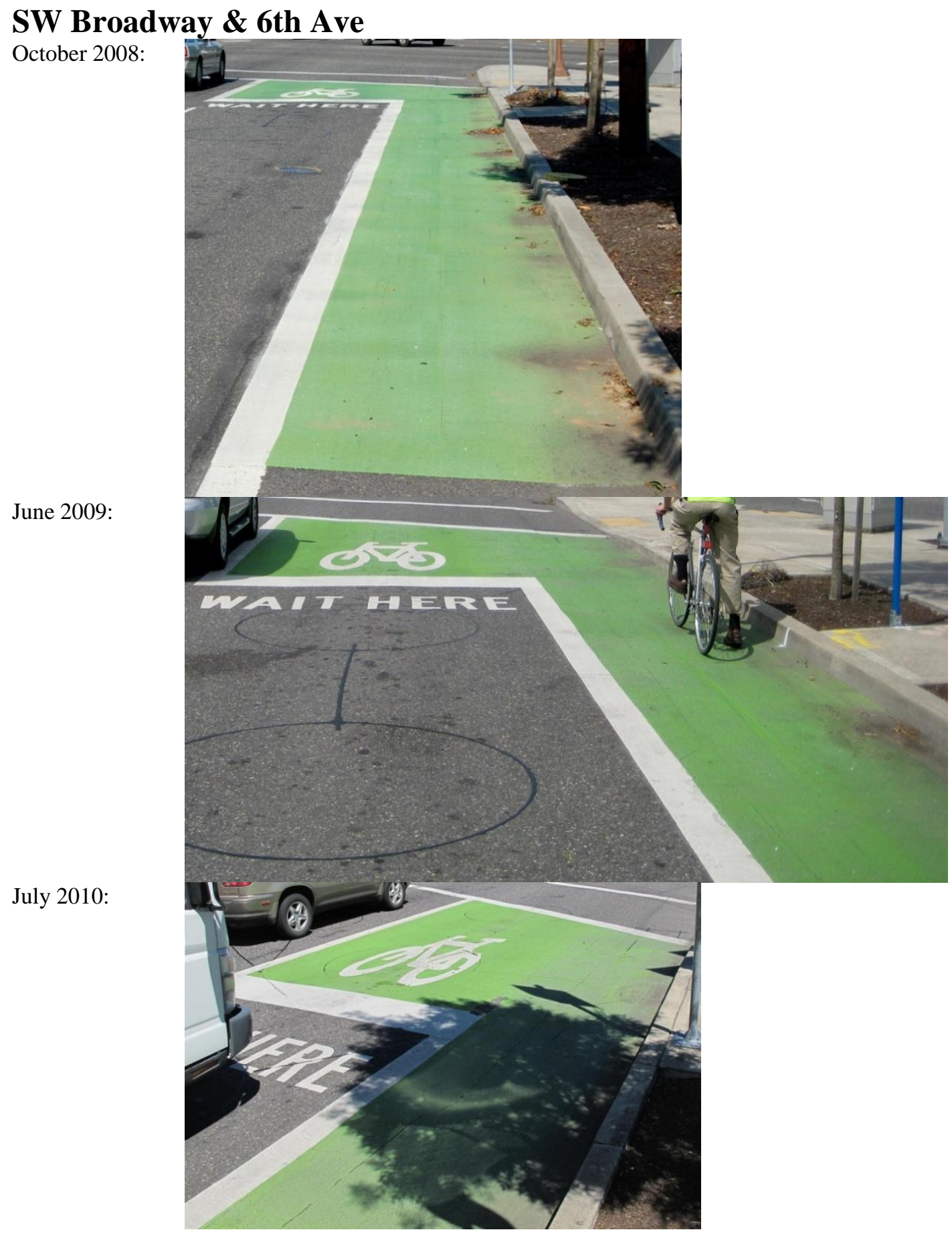

Daily Traffic Data from City of Portland:

\begin{tabular}{|c|c|c|c|c|c|c|c|}
\hline Location & Date & Type & Total & East & West & North & South \\
\hline SW 6th Ave, N/SW Broadway & 12-May-97 & Vol & 10841 & & & 10841 & \\
\hline NE BROADWAY E of 6TH AVE & 21-May-07 & Vol & 23467 & & 23467 & & \\
\hline
\end{tabular}




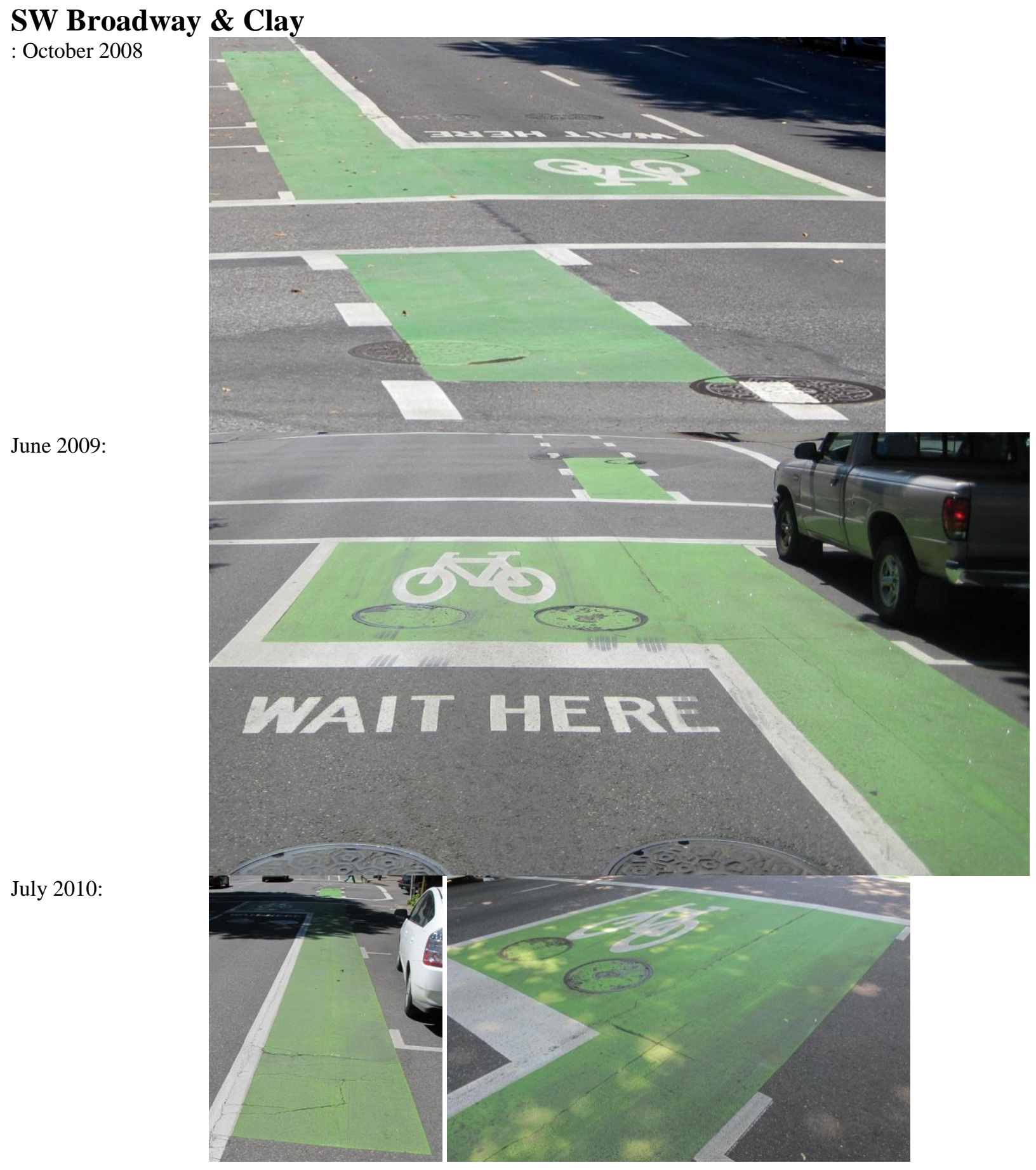




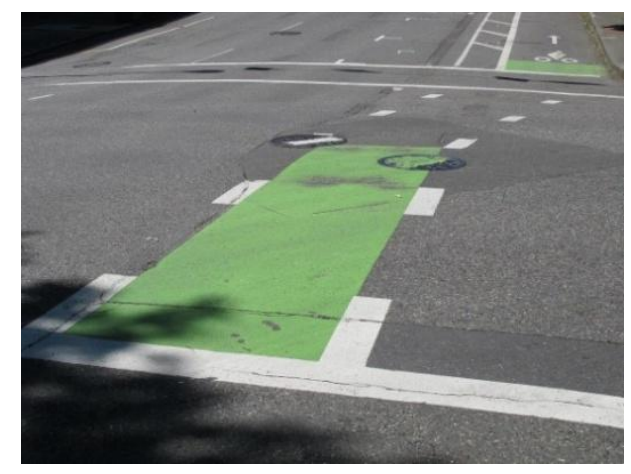

Daily Traffic Data from City of Portland:

\begin{tabular}{|c|c|c|c|c|c|c|c|}
\hline Location & Date & Type & Total & East & West & North & South \\
\hline SW CLAY ST, E/SW 3RD AVE & 14-Dec-06 & Vol & 8345 & & 8345 & & \\
\hline SW Clay St, E/SW Naito Pky (Front Ave) & 14-May-97 & Vol & 12708 & & 12708 & & \\
\hline SW Clay St, W/SW 13th Ave & $14-$ May-97 & Vol & 14223 & & 14223 & & \\
\hline
\end{tabular}




\section{SW Broadway \& Taylor}

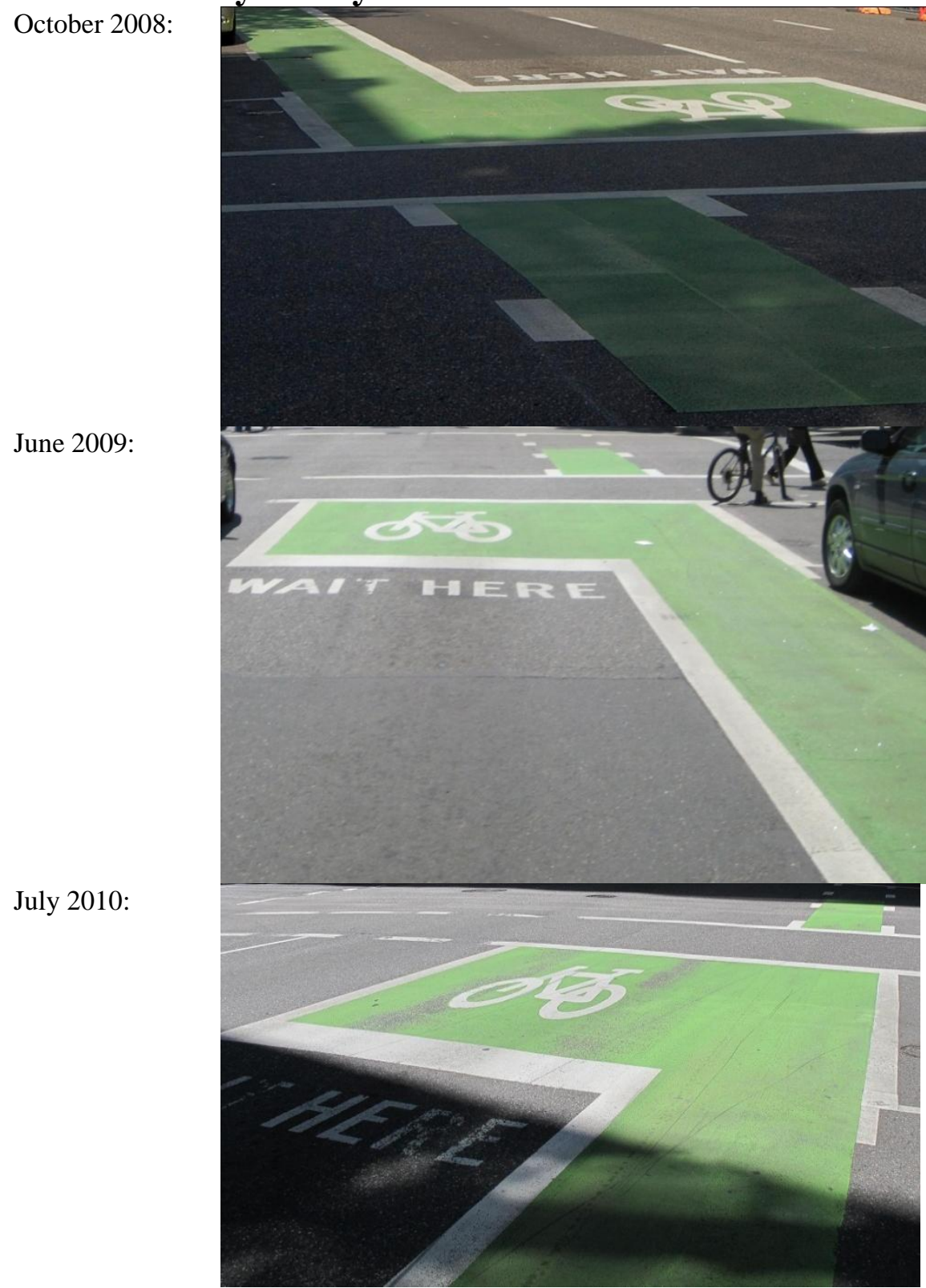

Daily Traffic Data from City of Portland:

\begin{tabular}{|l|c|c|c|c|r|r|r|}
\hline Location & Date & Type & Total & East & West & North & South \\
\hline SW Taylor St, E/SW Broadway & $17-S e p-01$ & Vol & 6747 & & 6747 & & \\
\hline SW Taylor St, E/SW Broadway & 13 -Dec-01 & Vol & 11921 & & 11921 & & \\
\hline SW Taylor St, E/SW Broadway & 25-Mar-02 & Vol & 7014 & & 7014 & & \\
\hline SW Taylor St, E/SW Broadway & $18-J u n-02$ & Vol & 9969 & & 9969 & & \\
\hline SW Broadway, N/SW Taylor St & $17-S e p-01$ & Vol & 14053 & & & & 14053 \\
\hline SW Broadway, N/SW Taylor St & 25-Mar-02 & Vol & 11761 & & & & 11761 \\
\hline SW Broadway, N/SW Taylor St & $18-J u n-02$ & Vol & 13352 & & & & 13352 \\
\hline
\end{tabular}

W Burnside \& 14th Ave 
October 2008:

August 2009:
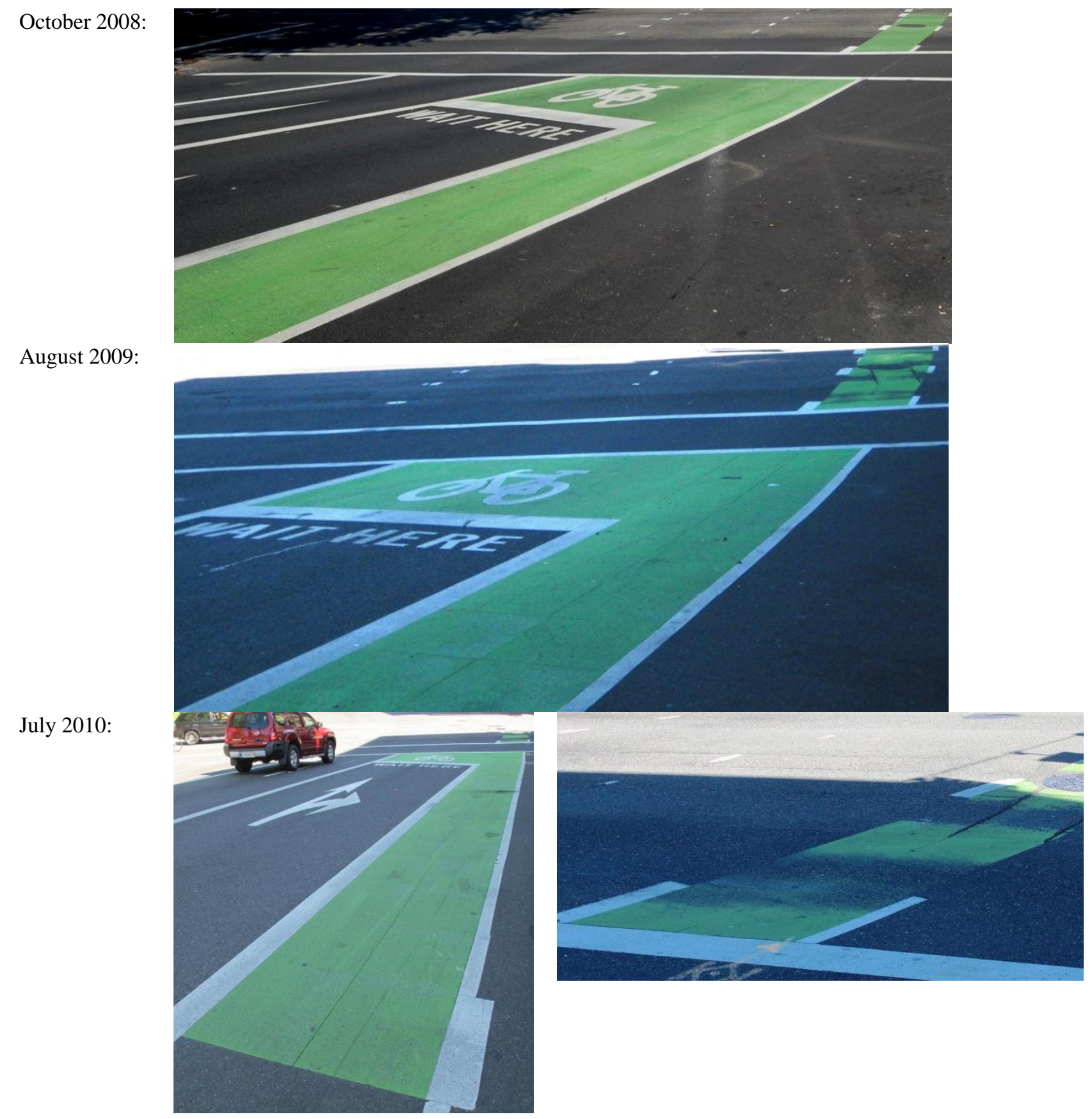

Daily Traffic Data from City of Portland:

\begin{tabular}{|c|c|c|c|c|c|c|c|}
\hline Location & Date & Type & Total & East & West & North & South \\
\hline SW 14th Ave, S/W Burnside St & 23-Sep-96 & Vol & 11550 & & & 11550 & \\
\hline SW 14th Ave, S/W Burnside St & 26-Mar-01 & Vol & 10625 & & & 10625 & \\
\hline SW 14th Ave, S/W Burnside St & 22-May-01 & Vol & 13102 & & & 13102 & \\
\hline W Burnside St, E/NW 14th Ave & 29-Apr-99 & Vol & 36144 & 17876 & 18268 & & \\
\hline W Burnside St, E/NW 14th Ave & 16-May-01 & Vol & 39231 & 19481 & 19750 & & \\
\hline
\end{tabular}




\section{APPENDIX B}

\section{B. CYCLIST AND MOTORIST SURVEYS}




\section{TEXT OF CYCLIST SURVEY}

\section{PSU Bicyclist Survey}

\section{Portland State}

\section{Dear Bicyclist,}

My name is Jennifer Dill, and I am a faculty member at Portland State University's Center for Transportation Studies. I am conducting a study about the bike boxes installed at several intersections in Portland. We hope that the results will help in future plans for improving bicycling in Portland and other cities.

Hearing from bicyclists like yourself is a very important part of this study. We have only invited a sample of bicyclists to participate in the study, by handing out postcards near several of the bike boxes. Therefore, every response is very important and we hope you will participate. To do so, you need to complete a survey, starting on the next page. It should take about 20 minutes.

Your participation in the survey is voluntary. We will protect the confidentiality of your individual survey responses. The postcard that you received has a unique number that you will need to enter on the next page. That number only identifies where and when we handed you the postcard. We will use your individual responses only for the purposes of this study and they will not be linked to your name or other identifying information. You may also stop taking the survey at any time, with no consequences.

At the end of the survey, you will be directed to another webpage with an offer to submit your name into a drawing for two $\$ 100$ gift certificates to the Bike Gallery. That information will not be linked with your survey responses. The survey must be completed by 10/31/09.

If you have concerns or problems about your participation in this study or your rights as a research subject, please contact the Human Subjects Research Review Committee, Office of Research and Sponsored Projects, 600 Unitus Bldg., Portland State University, (503) 725-4288 / 1-877-480-4400. If you have questions about the study itself, contact me at jdill@pdx.edu or 503-725-5173. If you are interested in learning more about me and the kind of research I do, please visit my web site at http://web.pdx.edu/ jdill/.

Sincerely, Jennifer Dill, Ph.D. Associate Professor Center for Transportation Studies 
Do you agree to participate in this survey?

$$
\begin{aligned}
& \text { No } \\
& \text { Yes }
\end{aligned}
$$

If you are under the age of $\mathbf{1 8}$, does your parent or guardian give permission for you to participate in this survey?

$\square$ Not applicable. I am 18 years or older.

No

participate

Yes, my parent or guardian has reviewed the information above and given me permission to

Please enter the unique ID number from the postcard you received about this survey.

When you received the postcard for this survey, where were you ...

coming FROM on your bicycle?

Work or school

Shopping, errands, personal business (e.g. bank, doctor), eating out, visiting friends, etc.

Home

No particular destination, exercise

I don't remember

Other (please specify)

If you selected other, please specify

going TO on your bicycle?

Work or school

Shopping, errands, personal business (e.g. bank, doctor), eating out, visiting friends, etc.

Home

No particular destination, exercise

I don't remember

Other (please specify)

If you selected other, please specify 
The postcard was handed to you at an intersection at or near a bike box. Please enter that intersection below.

SE Hawthorne and 7th Avenue (or SE Hawthorne and Grand)

NW Hoyt and Broadway (or NW Broadway/Lovejoy)

$\square$ West Burnside and 14th Avenue

SW Taylor and Broadway

SW Terwilliger and Taylors Ferry Road

Other (please specify)

If you selected other, please specify

The City of Portland installed a "bike box" at SE Hawthorne and 7th Avenue, for bikes traveling East on SE Hawthorne (see photo). Do you remember ever riding through the bike box area since it was installed?

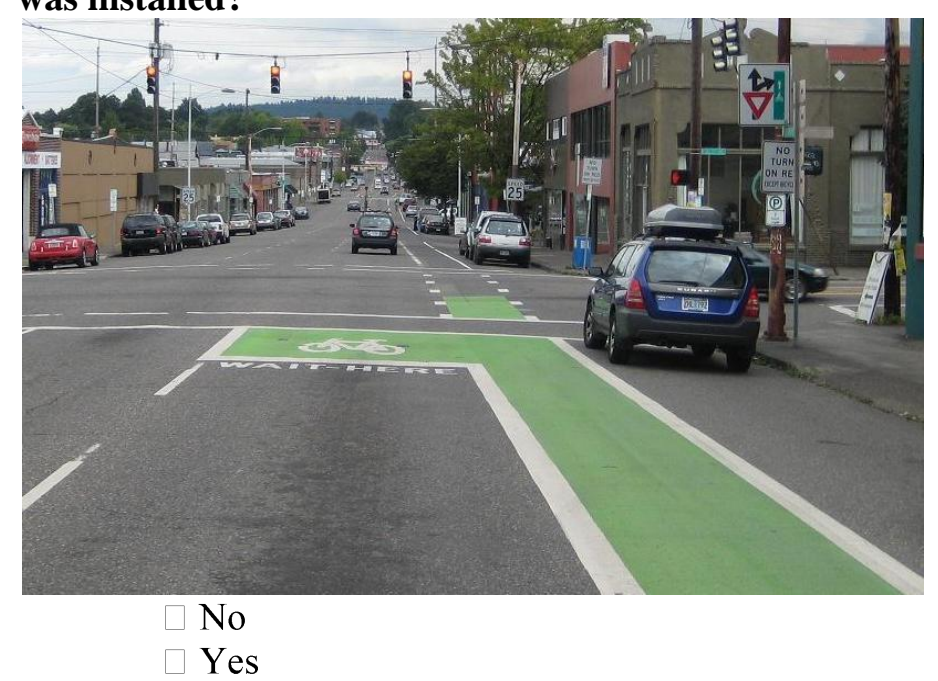

Before the bike box was installed, about how often did you ride your bicycle through this intersection, headed East on Hawthorne?

Never

Less than one day a month

1-3 days a month

1-3 days a week

4 or more days a week

I don't remember

Since the bike box was installed, about how often do you ride your bicycle through this intersection, headed East on Hawthorne?

1 Never

Less than one day a month

1-3 days a month

1-3 days a week

4 or more days a week

I don't know 
What do you think the purpose of the bike box is?

When should a bicyclist be in the box area, where the bike symbol is (see picture)?

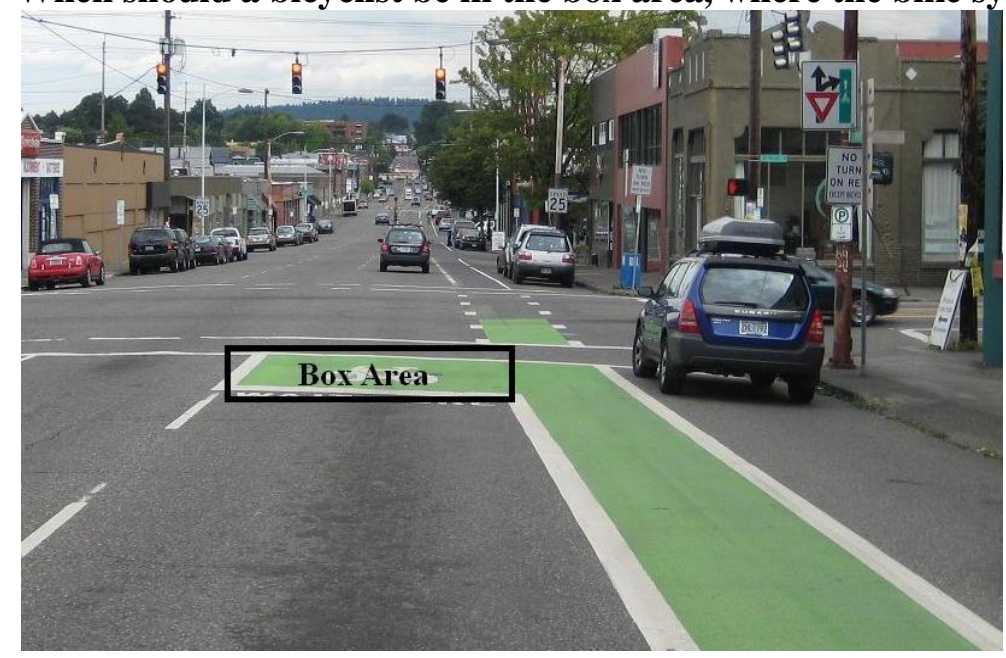

After the bike box, there is a painted area with dashed lines on each side (see photo). What do you think the purpose of that marking is?

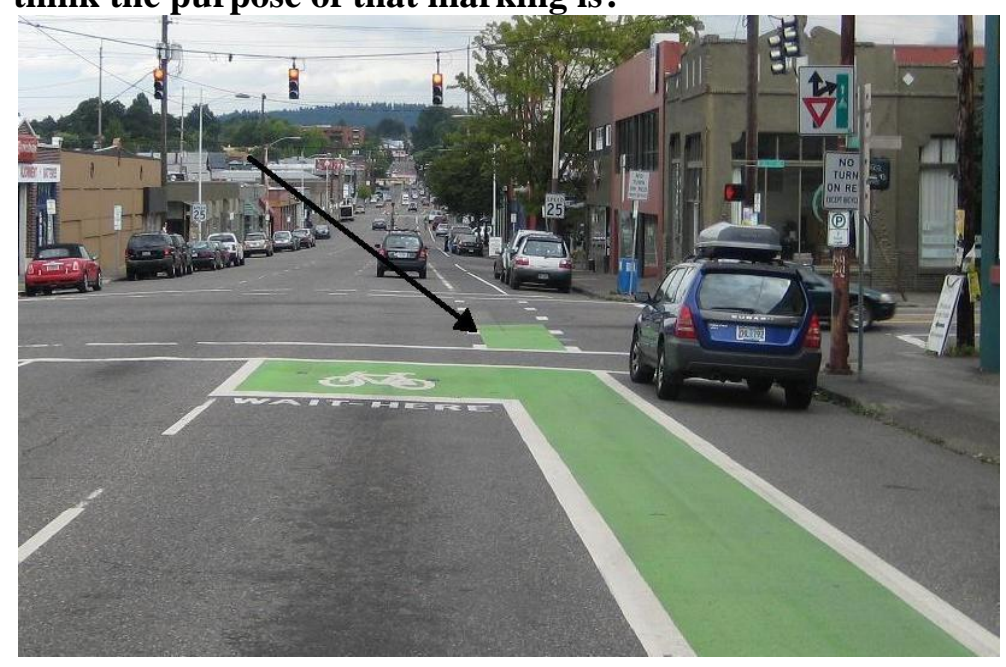


When you ride your bicycle through this intersection, which direction are you traveling most often? Choose only one answer

Going straight (East on Hawthorne)

Turning right (from Hawthorne to 7th Avenue headed South)

Turning left (from Hawthorne to 7th Avenue headed North)

When you ride your bicycle through this intersection, how often do you arrive at a red light?

Choose only one answer

Never

Rarely

Often, but less than half the time

About half the time

More than half the time

When you stop at a red light in the bike box area, where do you normally stop and wait? See photo. Choose only one answer

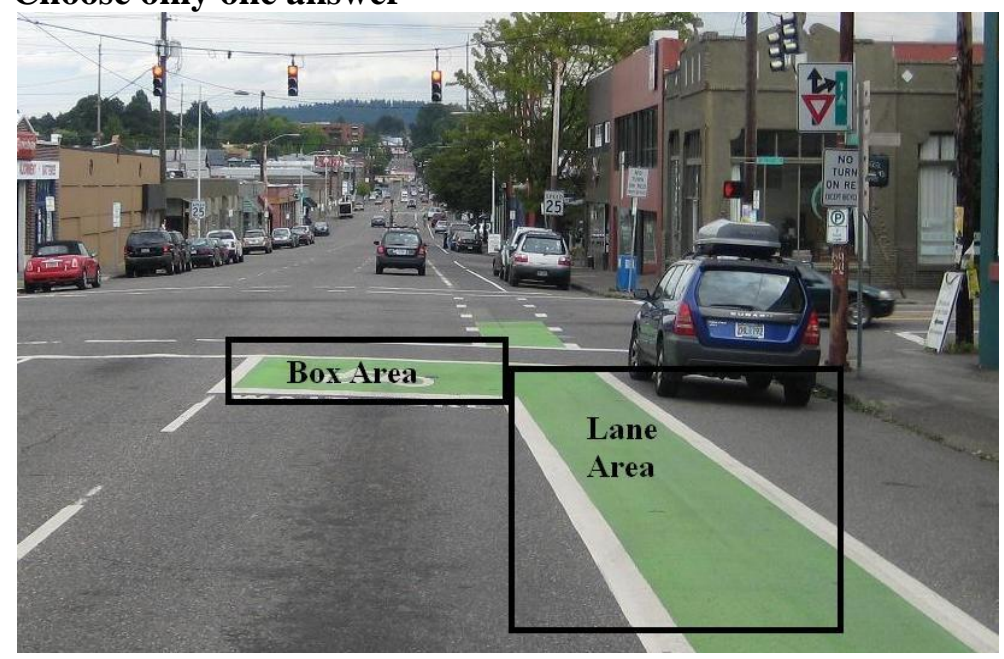

Within the box area, whether or not there are other bikes around

Within the box area, but only when there are other bikes around

In the bike lane area

Neither

I don't know

As a bicyclist, are you allowed to legally turn right on a red light, after stopping, at this location? Choose only one answer

$$
\begin{aligned}
& \square \text { Yes } \\
& \square \text { No } \\
& \square \text { I don't know }
\end{aligned}
$$

Are motor vehicles allowed to legally turn right on a red light, after stopping, at this location? Choose only one answer

$$
\begin{aligned}
& \text { Yes } \\
& \text { No } \\
& \text { I don't know }
\end{aligned}
$$


Do you think the bike box has made the intersection safer or more dangerous for you as a cyclist? Choose only one answer
A lot safer
A little safer
No Difference
A little more dangerous
A lot more dangerous
I don't know

If you answered that the bike box made the intersection safer or more dangerous, please specify why you believe that to be so?

Do you think the bike box has made the intersection easier or more difficult to use as a cyclist? Choose only one answer
A lot easier
A little easier
No Difference
A little more difficult
A lot more difficult
I don't know

If you answered that the bike box made the intersection easier or more difficult, please specify why you believe that to be so?

Do you think most motorists understand the purpose of the bike box at this intersection?
Yes
No
I don't know

While on your bicycle at this intersection, how often have you seen motor vehicles stopped at a red light partially or completely inside the bike box? Choose only one answer

Never

Rarely, less than $10 \%$ of the time

Often, about $10-50 \%$ of the time

Very Often, more than half of the time

Is there anything you think should be changed about the bike box at this intersection?

$$
\text { Yes }
$$

I don't know 
What should be changed about this intersection?

Has the installation of the bike box changed how you ride through this intersection?

No, I didn't ride through this intersection before it was installed

No, I ride through it the same as before

Yes

How has it changed how you ride through the intersection?

Have you ridden your bicycle through other intersections in Portland with bike boxes?

No, never

Yes, but not often

Yes, regularly

I don't know

Please indicate whether you agree or disagree with the following statements.

Motorists are more aware of cyclists because of the bike boxes in Portland.

Strongly disagree

Somewhat disagree

Neither

Somewhat agree

Strongly Agree

I don't know

The bike boxes make for a better environment for bicycling in Portland.

Strongly disagree

Somewhat disagree

Neither

Somewhat agree

Strongly Agree

I don't know

Do you think the City should install bike boxes at other intersections?
No
Yes
I don't know

Where should the city install other bike boxes? 
Do you have any other thoughts you would like to share about bike boxes?

On average during summer months (June-September), how many days per month do you ride your bicycle?
1
$\square 2$

$\sim$

30

31

During the non-summer months, about how many days per month do you ride your bicycle?

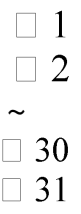

Which of these statements best describes your bicycling travel habits? Please choose only one answer.

My bicycle is my main mode of transportation year-round

My bicycle is my main mode of transportation during good weather. I drive or take transit more when the weather is bad. main mode.

$\checkmark$ I bicycle regularly for transportation (e.g. to work, school, shopping, errands), but it's not my

I rarely bicycle for transportation (e.g. to work, school, shopping, errands)

$\square$ I only bicycle for recreation or exercise, and not to get to places, such as work, school, shopping, errands, etc.

About how many years have you been bicycling regularly for transportation?

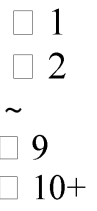

Please rate how comfortable you generally feel when cycling in heavy motor vehicle traffic. Please choose only one answer.

Very uncomfortable

Somewhat uncomfortable

Neither

Somewhat comfortable

Very comfortable 
In the past five years, how many (if any) of the following types of crashes have you been involved in as a bicyclist? Include all crashes, not just those that occurred in the City of Portland.

\begin{tabular}{|c|c|c|c|c|c|}
\hline & 0 & \begin{tabular}{|l|l|l|}
2 & 3 & 4 \\
\end{tabular} & \begin{tabular}{|l|l|l|l|l}
5 & 6 & 7 & 8 \\
\end{tabular} & 39 & $10+$ \\
\hline Crash with a motor vehicle where I was not injured & & & & & \\
\hline If one or more, how many of these crashes occurred at an intersection? & & & & & $\square$ \\
\hline Crash with a motor vehicle where I was injured & & & & & \\
\hline If one or more, how many of these crashes occurred at an intersection? & & & & & \\
\hline
\end{tabular}

\section{Some Questions about You}

We have a few questions about you and where you live, so that we may understand the characteristics of our survey respondents. Please remember that we will keep this information confidential.

Do you have a valid driver's license?

$$
\begin{aligned}
& \square \text { Yes } \\
& \text { No }
\end{aligned}
$$

On average, about how many miles per week do you drive any motor vehicle, including Zipcar (e.g. car, truck, van, motorcycle, SUV, etc.)? Enter 0 if none. Do not enter a range.

How many motor vehicles does your household own or lease? (Include motorcycles, cars, pick-up truck, vans, and SUVs, but not motorhomes, motor scooters, mopeds, or Zipcar).

What is your age?

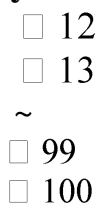

What is your gender?

Male

Female 
What is the highest grade or level of school you have completed?

Less than a high school diploma

High school Diploma or GED

Associate Degree (for example: AA, AS) or technical or vocational school

$\checkmark$ Some college, but no degree

Bachelor's degree (for example: BA, AB, BS)

$\checkmark$ Some graduate study, but no degree

Graduate or professional degree (Master's, professional, (e.g. law, medicine, doctorate)

Are you currently... Check as many as apply.

Employed full-time

Employed part-time

Unemployed and looking for work

Retired

Going to school

Homemaker

$\checkmark$ Disabled and on disability, not working

Other (please specify)

If you selected other, please specify

What is the nearest intersection to your home? (NOT necessarily an intersection with a bike box.)

Is there anything else you would like to share with us?

Those are all of the questions we have. Thank you very much for your time. Please click the "submit survey" button below.

If you would like to enter the random drawing for two $\$ 100$ gift certificates to the Bike Gallery, enter your information on the next page.

Thank you!

Jennifer Dill, Ph.D.

Portland State University

jdill@pdx.edu 


\section{TEXT OF MOTORIST SURVEY}

\section{PSU Intersection Study: Driver Survey}

Hello!

My name is Jennifer Dill, and I am a faculty member at Portland State University. I am conducting a study on traffic and the design of intersections in the City of Portland. As part of the study, we need to learn from the experiences of drivers in the area around downtown. This research will be useful in helping design roads in the future.

Hearing from drivers like yourself is a very important part of this study. You were invited to participate in this study because you live or work in one of the neighborhoods we are studying. Every response is very important and we hope you will participate. To do so, you need to complete a survey, starting on the next page. It should take about 20 minutes.

Your participation in the survey is voluntary. We will protect the confidentiality of your individual survey responses. We will use your individual responses only for the purposes of this study and they will not be linked to your name or other identifying information. You may also stop taking the survey at any time, with no consequences.

At the end of the survey, you will be directed to another webpage with an offer to submit your name into a random drawing for three $\$ 100$ gift certificates to your choice of four merchants (Fred Meyer, New Seasons, Powell's, or Starbucks). In addition, the first ten (10) respondents will receive gift certificates of $\$ 25$ to the merchant of their choice (from the list above). Contact information for the drawing will be used to notify certificate recipients and will not be linked with your survey responses. The survey must be completed by Tuesday, December 1st, 2009.

If you have concerns or problems about your participation in this study or your rights as a research subject, please contact the Human Subjects Research Review Committee, Office of Research and Sponsored Projects, 600 Unitus Bldg., Portland State University, (503) 725-4288 / 1-877-480-4400. If you have questions about the study itself, contact me at jdill@pdx.edu or 503-725-5173. If you are interested in learning more about me and the kind of research I do, please visit my web site at http://web.pdx.edu/ jdill/.

Sincerely,

Jennifer Dill, Ph.D.

Associate Professor

Center for Transportation Studies 
1) Do you agree to participate in this survey?

$\square$ No

$\square$ Yes

2) If you are under the age of 18 , does your parent or guardian give permission for you to participate in this survey?
Not applicable. I am 18 years or older.
No
Yes, my parent or guardian has reviewed the information above and given me permission to

participate

3) This survey is intended for people with a valid driver's license who have driven a motor vehicle in Portland during 2009. Do you have a valid driver's license?

$$
\begin{aligned}
& \text { No } \\
& \text { Yes }
\end{aligned}
$$

4) During 2009, about how often have you driven a motor vehicle within the city limits of the City of Portland?

Never

Less than once a week

1-3 days per week

4 or more days per week

5) Have you ever driven a motor vehicle through an intersection in the City of Portland with a pavement marking, as shown in the photos below?

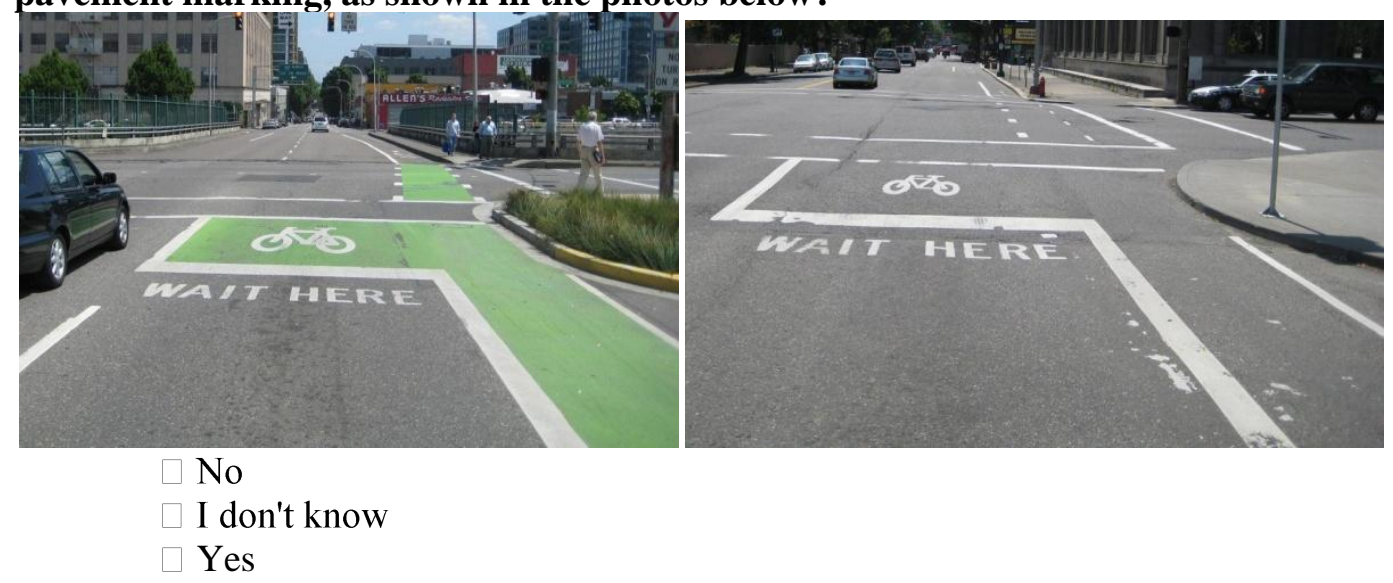

6) What do you think the purpose of this pavement marking is? 
7) If you approached an intersection with a red light and there were no bicycles at the intersection, where should you stop your car to wait for the green light? Please refer to Figure A and Figure B.

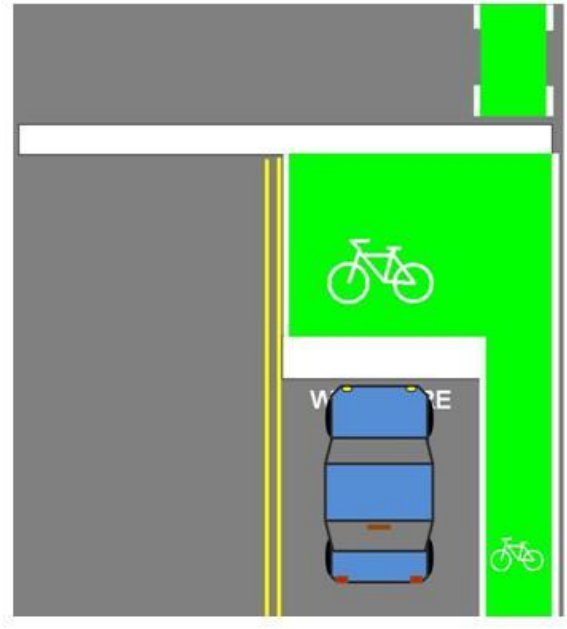

Figure A

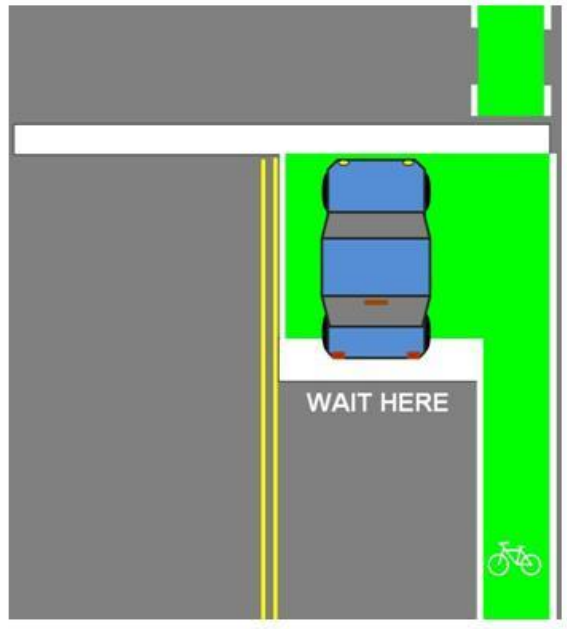

Figure B

Figure A

Figure B

Figure A or Figure B

Neither

I don't know

8) If you approached an intersection with a red light and there was a bicycle, as shown in Figure A and Figure B, where should you stop your car to wait for the green light?

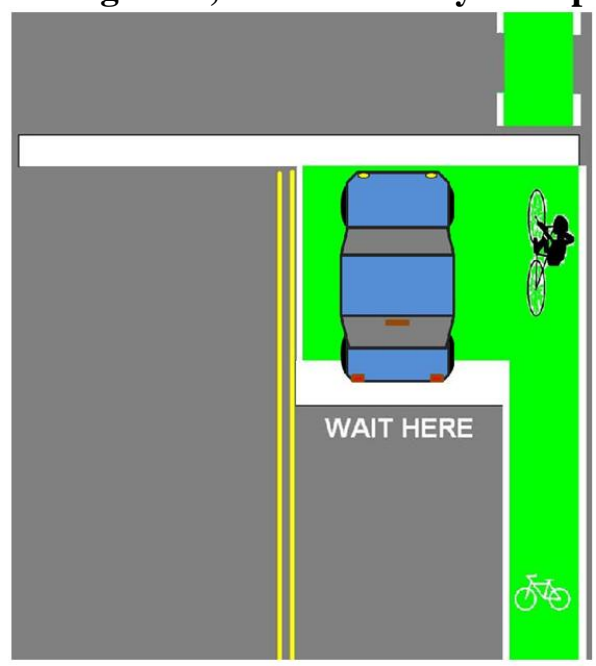

Figure A

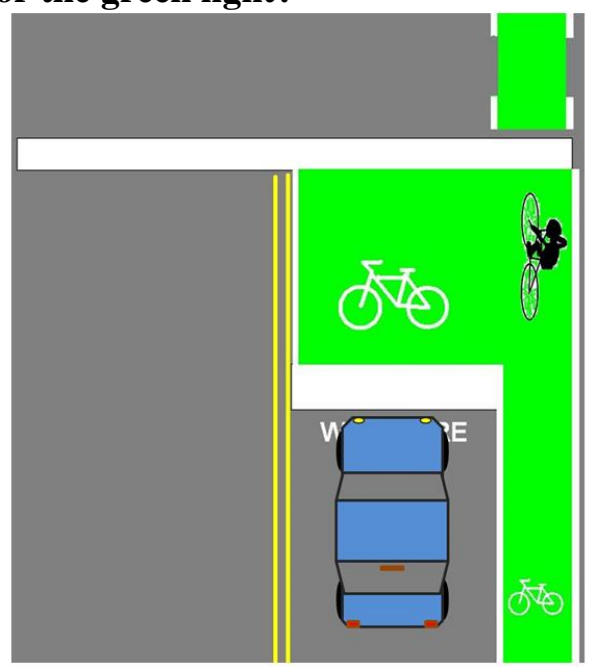

Figure B

Figure A

Figure B

Figure A or Figure B

Neither

I don't know 
9) In the picture below, the white car is waiting at a red light. Is the car stopped in the correct location?

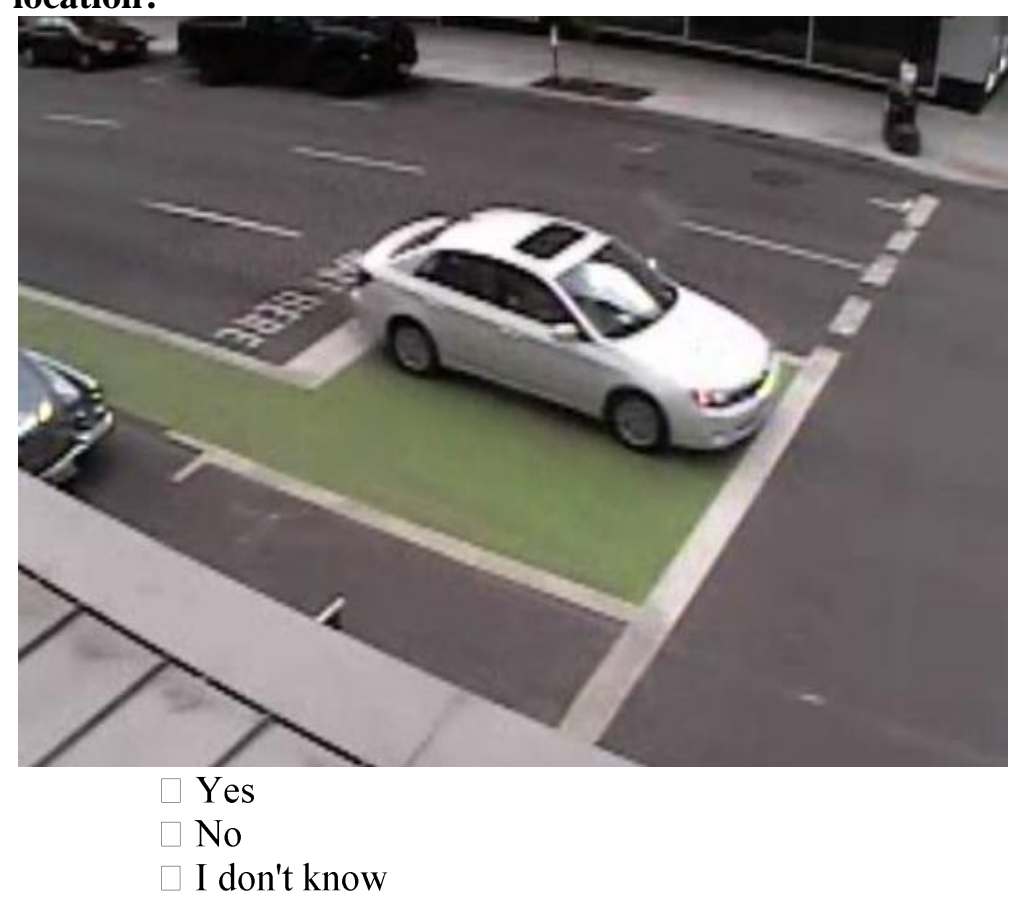

10) In the picture below, the white SUV and the bicycle are waiting at a red light. Is the SUV stopped in the correct location?

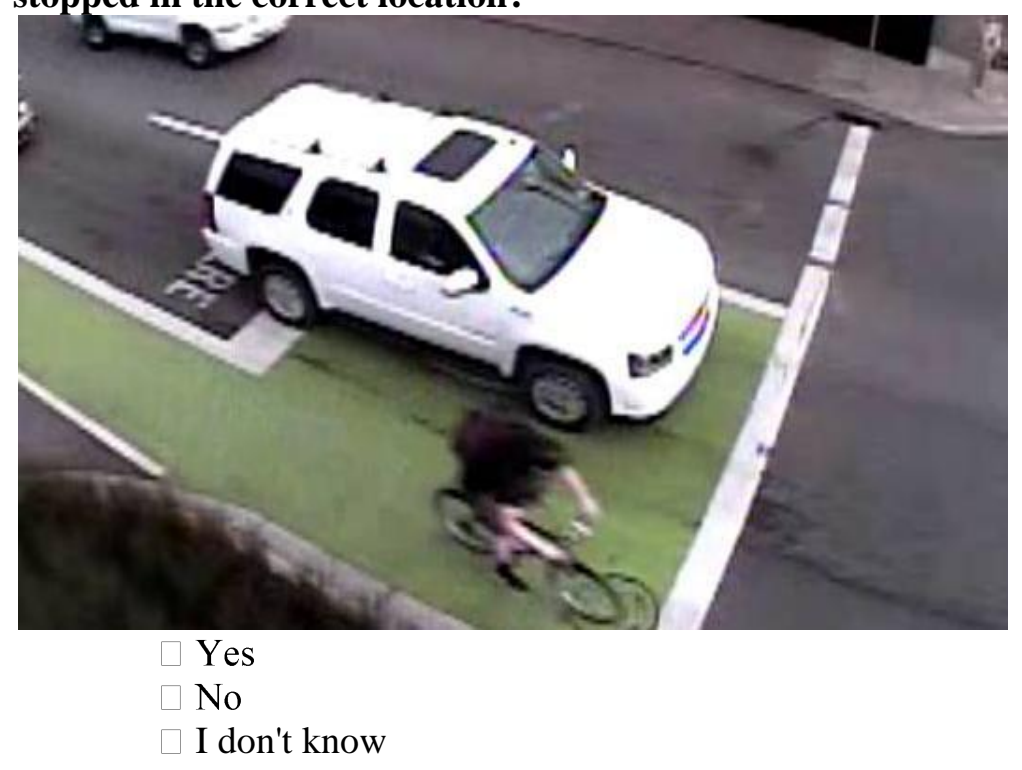


11) The pavement markings in the previous photos are called "bike boxes." Looking at the photo below, imagine that you are driving a car in the same lane as the bicyclist. The light is green and you plan on driving straight. Are you supposed to change lanes to the left to avoid driving in the bike box?

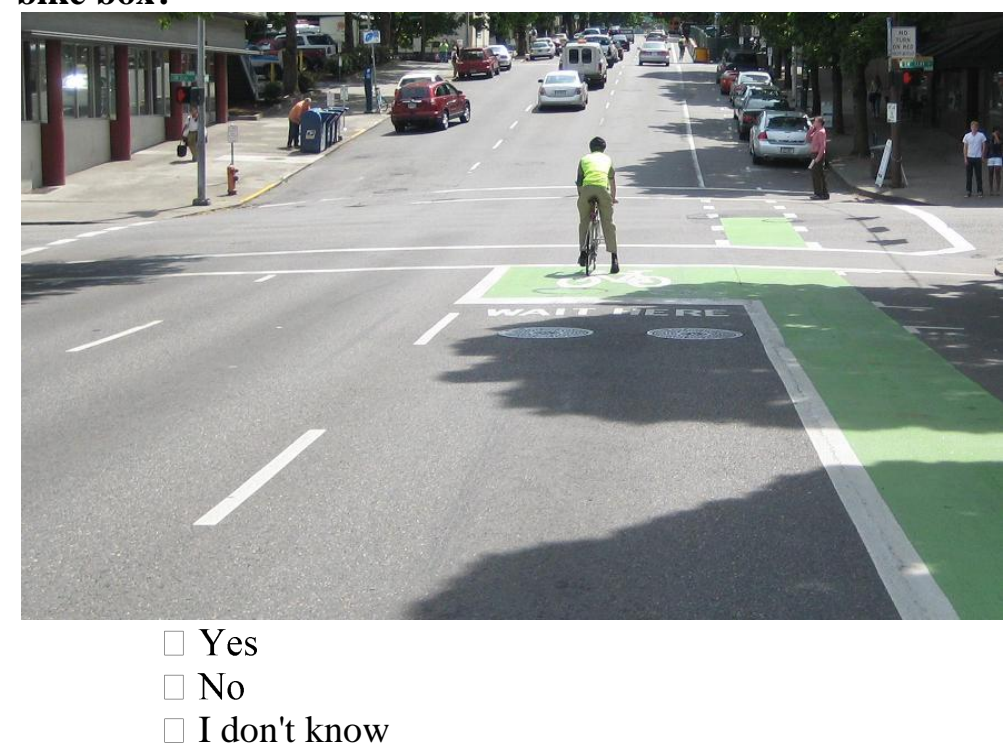

12) About how often have you driven a motor vehicle through a City of Portland intersection with a bike box, in the direction of the bike box (e.g. driving in the lane with the box or the lane(s) next to it)?

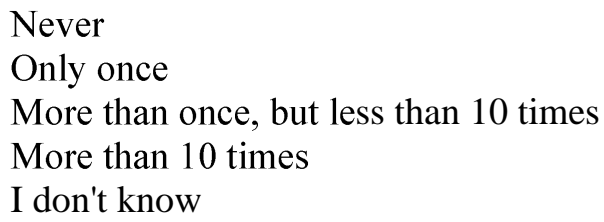

13) When you have driven through Portland intersections with bike boxes, did you see any traffic signs about the bike box at the intersection?
Yes
No
I don't know

14) What did the signs say? 
15) Looking at the picture below, what do you think the sign means?

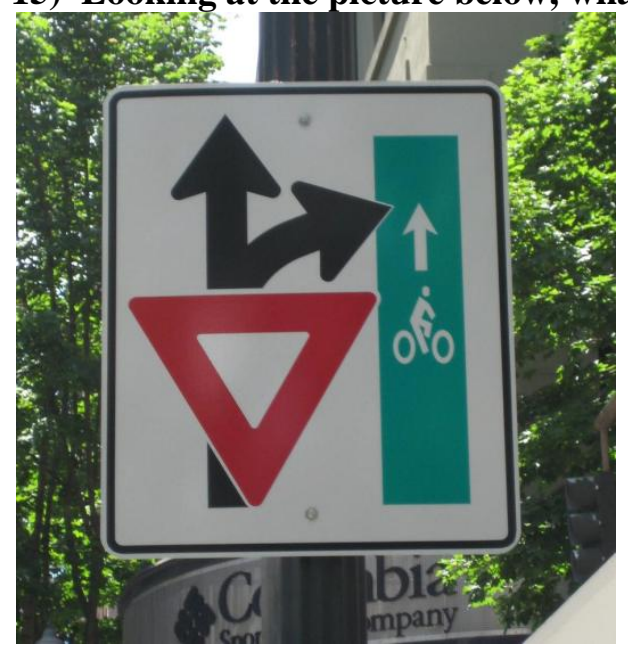

16) Looking at the picture below, what do you think the sign means?

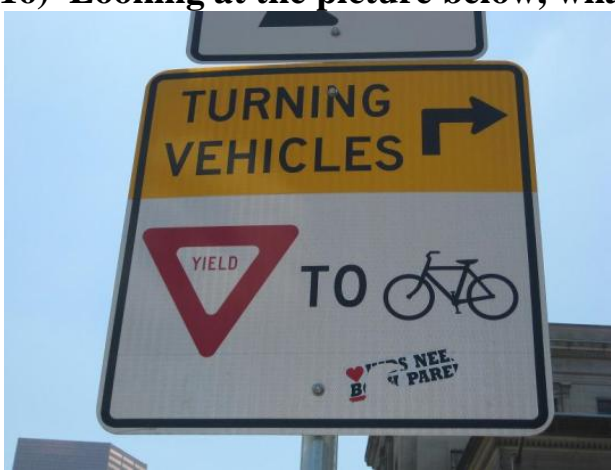

17) In the past year, do you remember seeing any billboards in the City of Portland about bike boxes?

Yes
No
I don't know

18) If yes, what did the billboards say? 
19) There are two types of bike boxes in the City of Portland, both shown in the photos below. As a driver, do you think one of the pavement marking designs is better than the other?

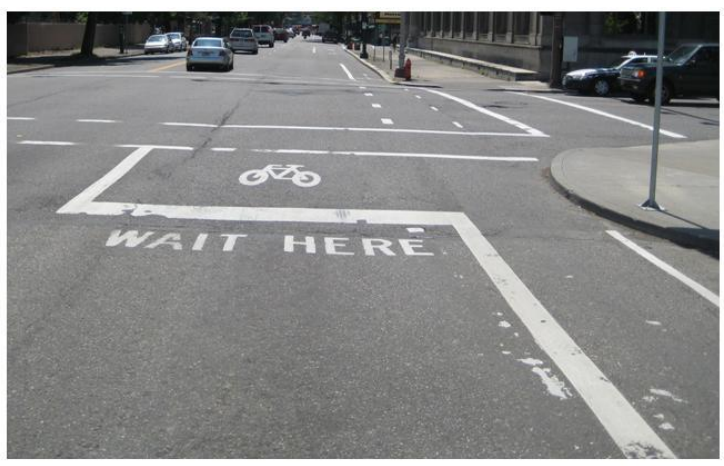

Figure A

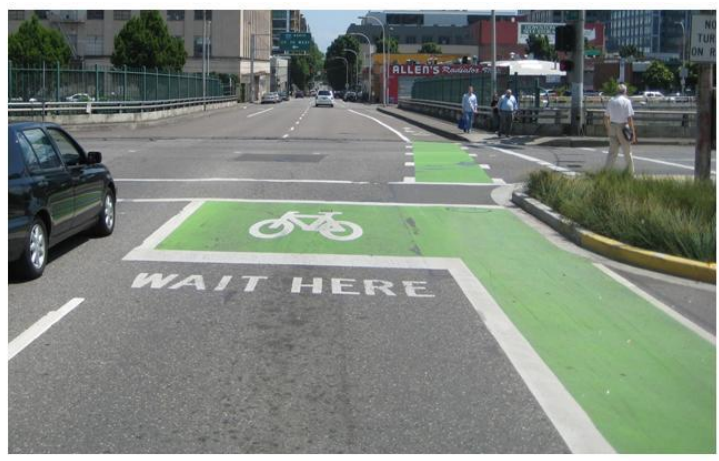

Figure B

The pavement marking in Figure A is better than in Figure B

The pavement marking in Figure B is better than in Figure A

Both are about the same

I don't know

20) If you preferred one pavement marking over the other, why? If you had no preference, you may leave this question blank.

21) Do you think the bike box has made driving safer or more dangerous at the intersections where they are installed?

Choose only one answer
A lot safer
A little safer
No difference
A little more dangerous
A lot more dangerous
I don't know

22) Why do you think the bike box has made driving safer or less safe? If you answered "no difference" on the previous question, you may leave this answer blank.

23) About how often have you ridden a bicycle through a City of Portland intersection with a bike box, in the direction of the bike box?

Never

Only once

More than once, but less than 10 times

More than 10 times

I don't know 
24) Do you think the bike boxes have made bicycling safer or more dangerous at the intersections where they are installed?

Choose only one answer
A lot safer
A little safer
No difference
A little more dangerous
A lot more dangerous
$\exists$ I don't know

25) Why do you think the bike boxes have made bicycling safer or less safe? If you answered "no difference" on the previous question, you may leave this answer blank.

26) Do you think motorists drive more safely because of the bike boxes?

$$
\begin{aligned}
& \square \text { Yes } \\
& \text { No } \\
& \text { I don't know }
\end{aligned}
$$

27) Do you think bicyclists ride more safely because of the bike boxes?

$$
\begin{aligned}
& \square \text { Yes } \\
& \text { No } \\
& \text { I don't know }
\end{aligned}
$$

28) Do you think the bike boxes have made driving more or less convenient at the intersections where they are installed? Choose only one answer
A lot more convenient
A little more convenient
No difference
A little less convenient
$\square$ A lot less convenient
I don't know

29) Why do you think that the bike boxes have made driving more or less convenient? If you answered "no difference" on the previous question, you may leave this answer blank.

30) Do you think the bike boxes have made you feel more comfortable driving through the intersections when bicyclists are nearby? Choose only one answer
A lot more comfortable
A little more comfortable
No difference
A little less comfortable
A lot less comfortable
I don't know 
31) Why have the bike boxes made you feel more or less comfortable when driving through the intersections? If you answered "no difference" on the previous question, you may leave this answer blank.

32) Has the installation of the bike boxes changed how you drive through the intersections with bike boxes?

No

Yes

33) How has it changed how you drive through the intersection?

34) Has the installation of the bike boxes changed how you drive through intersections without bike boxes?

No

Yes

35) How has it changed how you drive through other intersections?

36) Do you have any other thoughts you would like to share about bike boxes?

37) On streets and traffic signs, different colors often have a particular meaning. What, if any, color(s) on roads and signs do you associate with bicycles or bicycling?

Check all that apply.

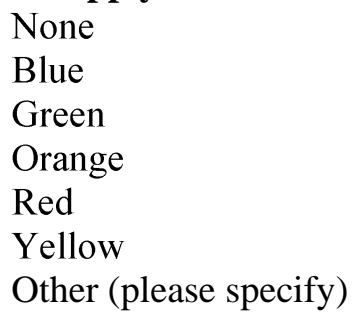

None

Blue

Green

Orange

Red

Yellow

Other (please specify)

If you selected other, please specify 
Please indicate whether you agree or disagree with the following statements.

38) The City of Portland should be doing more to improve bicycle safety.

Strongly disagree

Somewhat disagree

Somewhat agree

$\checkmark$ Strongly agree

No opinion

39) Do you think the bike boxes make drivers more aware of bicyclists generally, not just at the intersections?

No

Yes

$\neg$ I don't know

40) Do you agree or disagree with the following statement? Many bicyclists disobey traffic laws, causing problems for motorists and traffic.

Choose only one answer

Strongly agree

Somewhat agree

$\checkmark$ Neither

Somewhat disagree

Strongly disagree

I don't know

41) Do you think the City should install bike boxes at other intersections or remove them from some intersections?

The City should install more bike boxes

The City should remove some or all of the bike boxes

Neither. The City should not install more bike boxes or remove any of the existing ones

$\square$ I don't know

42) The City of Portland should be doing more to increase the number of people bicycling.

Strongly disagree

Somewhat disagree

Somewhat agree

Strongly agree

No opinion

43) In the past few years in Portland, do you remember reading or hearing about any motor vehicles turning right and hitting a bicyclist?
No
Yes
I don't know

44) As a driver, have you ever been involved in a crash with a bicyclist?

No

Yes

I don't know 
45) As a driver, have you ever been involved in a near miss with a bicyclist (e.g. almost crashing)? No

Yes

I don't know

46) As a bicyclist, have you ever been involved in a crash with a motor vehicle?

$\square$ No, I do not bicycle

$\square$ No, I bicycle, but have not been in a crash with a motor vehicle

Yes

I don't know

47) Do you own a working bicycle?

\section{No}

Yes

48) On average during summer months (June-September), how many days per month do you ride your bicycle?

$\square 0$
$\square 1$
$\sim$
$\square 30$
$\square 31$

49) During the non-summer months, about how many days per month do you ride your bicycle?

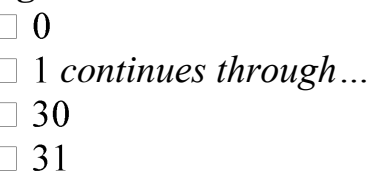

50) On average, about how many miles per week do you drive a motor vehicle (e.g. car, truck, van, motorcycle, SUV, etc.)? Enter 0 if none. Do not enter a range.

51) What is your age?

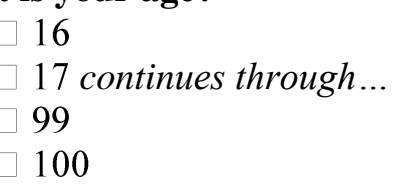

52) What is your gender?

Male

Female

53) What is the highest grade or level of school you have completed?

Less than a high school diploma

High school Diploma or GED

$\square$ Associate Degree (for example: AA, AS) or technical or vocational school

Some college, but no degree

Bachelor's degree (for example: BA, AB, BS)

Some graduate study, but no degree

Graduate or professional degree (Master's, professional, (e.g. law, medicine), doctorate) 
54) Are you currently... Check as many as apply.

Employed full-time

Employed part-time

Unemployed and looking for work

Retired

Going to school

Homemaker

Disabled and on disability, not working

Other (please specify)

If you selected other, please specify

55) What city do you live in?

Portland

Gresham

Beaverton

Hillsboro

Vancouver, WA

List of cities continued....

Other (please specify)

If you selected other, please specify

56) What is the nearest intersection to your home? (NOT necessarily an intersection with a bike box.)

57) Is there anything else you would like to share with us?

Those are all of the questions we have. Thank you very much for your time. After you press "submit survey" you will be redirected to another page where you may enter a random drawing for three $\$ 100$ gift certificates to your choice of four merchants (Fred Meyer, New Seasons, Powell's, or Starbucks), and for the ten $\$ 25$ gift certificates for the first ten respondents.

Thank you!

Jennifer Dill, Ph.D.

Portland State University

jdill@pdx.edu 



\section{APPENDIX C}

\section{C.SURVEY RESPONSES}




\section{CYCLIST SURVEY RESPONSES}

Where were you coming FROM on your bicycle?

\begin{tabular}{ll}
\hline & Percent \\
\hline Other & 0.7 \\
Work or school & 49.3 \\
Shopping, errands, personal business (e.g. bank, doctor), eating out, visiting friends, etc. & 1.7 \\
Home & 47.8 \\
No particular destination, exercise & 0.4 \\
Total & 100.0 \\
$\mathrm{n}$ & 458 \\
\hline
\end{tabular}

Where were you going TO on your bicycle?

\begin{tabular}{ll}
\hline & Percent \\
\hline Other & 1.6 \\
Work or school & 52.3 \\
Shopping, errands, personal business (e.g. bank, doctor), eating out, visiting friends, etc. & 4.4 \\
Home & 41.1 \\
No particular destination, exercise & 0.7 \\
Total & 100.0 \\
$\mathrm{n}$ & 436 \\
\hline
\end{tabular}

The postcard was handed to you at an intersection at or near a bike box. Please enter that intersection below.

\begin{tabular}{ll}
\hline & Percent \\
\hline SE Hawthorne and 7th Avenue (or SE Hawthorne and Grand) & 43.8 \\
NW Hoyt and Broadway (or NW Broadway/Lovejoy) & 46.2 \\
West Burnside and 14th Avenue & 6.0 \\
SW Taylor and Broadway & 2.8 \\
SW Terwilliger and Taylors Ferry Road & 1.3 \\
Total & 100.0 \\
$\mathrm{n}$ & 468 \\
\hline
\end{tabular}

The City of Portland installed a "bike box" at [the intersection where the cyclist received the postcard], for bikes travelling [in the approaching direction] on [street]. Do you remember ever riding through the bike box area since it was installed?

\begin{tabular}{lllllll}
\hline & $\begin{array}{c}\text { SE } \\
\text { Hawthorne } \\
\text { at 7th }\end{array}$ & $\begin{array}{c}\text { NW } \\
\text { Broadway } \\
\text { at Hoyt }\end{array}$ & $\begin{array}{c}\text { SW } \\
\text { Broadway } \\
\text { at Taylor }\end{array}$ & $\begin{array}{c}\text { SW } \\
\text { Terwilliger } \\
\text { at Taylors } \\
\text { Ferry }\end{array}$ & $\begin{array}{c}\text { SW 14 } \\
\text { Burnside }\end{array}$ & Total \\
\hline No & 5.0 & 7.9 & 0.0 & 0.0 & 3.7 & 6.0 \\
Yes & 95.0 & 92.1 & 100.0 & 100.0 & 96.3 & 94.0 \\
Total & 100.0 & 100.0 & 100.0 & 100.0 & 100.0 & 100.0 \\
$\mathrm{n}$ & 220 & 203 & 12 & 6 & 27 & 468 \\
\hline
\end{tabular}


Before the bike box was installed, about how often did you ride your bicycle through this intersection, headed [in the approaching direction] on [street]?

\begin{tabular}{lllllll}
\hline & $\begin{array}{c}\text { SE } \\
\text { Hawthorne } \\
\text { at 7th }\end{array}$ & $\begin{array}{c}\text { NW } \\
\text { Broadway } \\
\text { at Hoyt }\end{array}$ & $\begin{array}{c}\text { SW } \\
\text { Broadway } \\
\text { at Taylor }\end{array}$ & $\begin{array}{c}\text { SW } \\
\text { Terwilliger } \\
\text { at Taylors } \\
\text { Ferry }\end{array}$ & $\begin{array}{c}\text { SW 14 } \\
\text { Burnside }\end{array}$ & Total \\
\hline Never & 16.3 & 9.7 & 8.3 & 16.7 & 30.8 & 14.1 \\
Less than one day a month & 7.7 & 5.9 & 0.0 & 0.0 & 19.2 & 7.3 \\
1-3 days a month & 9.6 & 5.9 & 16.7 & 16.7 & 7.7 & 8.2 \\
1-3 days a week & 18.7 & 11.8 & 16.7 & 50 & 11.5 & 15.7 \\
4 or more days a week & 44.5 & 60.2 & 50 & 16.7 & 19.2 & 49.4 \\
I don't remember & 3.3 & 6.5 & 8.3 & 0.0 & 11.5 & 5.2 \\
Total & 100.0 & 100.0 & 100.0 & 100.0 & 100.0 & 100.0 \\
$\mathrm{n}$ & 209 & 186 & 12 & 6 & 26 & 439 \\
\hline
\end{tabular}

Since the bike box was installed, about how often did you ride your bicycle through this intersection, headed [in the approaching direction] on [street]?

\begin{tabular}{lllllll}
\hline & $\begin{array}{c}\text { SE } \\
\text { Hawthorne } \\
\text { at 7th }\end{array}$ & $\begin{array}{c}\text { NW } \\
\text { Broadway } \\
\text { at Hoyt }\end{array}$ & $\begin{array}{c}\text { SW } \\
\text { Broadway } \\
\text { at Taylor }\end{array}$ & $\begin{array}{c}\text { SW } \\
\text { Terwilliger } \\
\text { at Taylors } \\
\text { Ferry }\end{array}$ & $\begin{array}{c}\text { SW 14 } \\
\text { Burnside }\end{array}$ & Total \\
\hline Less than one day a month & 4.8 & 3.7 & 8.3 & 16.7 & 15.4 & 5.2 \\
1-3 days a month & 11 & 3.7 & 25 & 16.7 & 11.5 & 8.4 \\
1-3 days a week & 23 & 17.6 & 16.7 & 33.3 & 23.1 & 20.7 \\
4 or more days a week & 61.2 & 74.9 & 50 & 33.3 & 46.2 & 65.5 \\
I don't know & 0.0 & 0.0 & 0.0 & 0.0 & 3.8 & 0.2 \\
Total & 100.0 & 100.0 & 100.0 & 100.0 & 100.0 & 100.0 \\
n & 209 & 187 & 12 & 6 & 26 & 440 \\
\hline
\end{tabular}

When you ride your bicycle through this intersection, which direction are you traveling most often?

\begin{tabular}{lllllll}
\hline & $\begin{array}{c}\text { SE } \\
\text { Hawthorne } \\
\text { at 7th }\end{array}$ & $\begin{array}{c}\text { NW } \\
\text { Broadway } \\
\text { at Hoyt }\end{array}$ & $\begin{array}{c}\text { SW } \\
\text { Broadway } \\
\text { at Taylor }\end{array}$ & $\begin{array}{c}\text { SW } \\
\text { Terwilliger } \\
\text { at Taylors } \\
\text { Ferry }\end{array}$ & $\begin{array}{c}\text { SW 14 } \\
\text { Burnside }\end{array}$ & Total \\
\hline Going straight & 85.8 & 96.6 & 91.7 & 100.0 & 100.0 & 91.6 \\
Turning right & 5.5 & 3.4 & 8.3 & 0.0 & 0.0 & 4.3 \\
Turning left & 8.7 & 0.0 & 0.0 & 0.0 & 0.0 & 4.1 \\
Total & 100.0 & 100.0 & 100.0 & 100.0 & 100.0 & 100.0 \\
$\mathrm{n}$ & 218 & 203 & 12 & 6 & 27 & 466 \\
\hline
\end{tabular}


When you ride your bicycle through this intersection, how often do you arrive at a red light?

\begin{tabular}{|c|c|c|c|c|c|c|}
\hline & $\begin{array}{c}\text { SE } \\
\text { Hawthorne } \\
\text { at } 7 \text { th }\end{array}$ & $\begin{array}{c}\text { NW } \\
\text { Broadway } \\
\text { at Hoyt }\end{array}$ & $\begin{array}{c}\text { SW } \\
\text { Broadway } \\
\text { at Taylor }\end{array}$ & $\begin{array}{c}\text { SW } \\
\text { Terwilliger } \\
\text { at Taylors } \\
\text { Ferry }\end{array}$ & $\begin{array}{c}\text { SW 14 } \\
\text { Burnside }\end{array}$ & Total \\
\hline Never & 0.9 & 0.5 & 0.0 & 0.0 & 3.7 & 0.9 \\
\hline Rarely & 37.2 & 11.3 & 27.3 & 0.0 & 0.0 & 22.9 \\
\hline $\begin{array}{l}\text { Often, but less than half the } \\
\text { time }\end{array}$ & 26 & 20.7 & 45.5 & 16.7 & 0.0 & 22.5 \\
\hline About half the time & 23.3 & 47.3 & 18.2 & 50 & 14.8 & 33.5 \\
\hline More than half the time & 12.6 & 20.2 & 9.1 & 33.3 & 81.5 & 20.1 \\
\hline Total & 100.0 & 100.0 & 100.0 & 100.0 & 100.0 & 100.0 \\
\hline $\mathrm{n}$ & 215 & 203 & 11 & 6 & 27 & 462 \\
\hline
\end{tabular}

When you stop at a red light in the bike box area, where do you normally stop and wait? See photo. Choose only one answer.

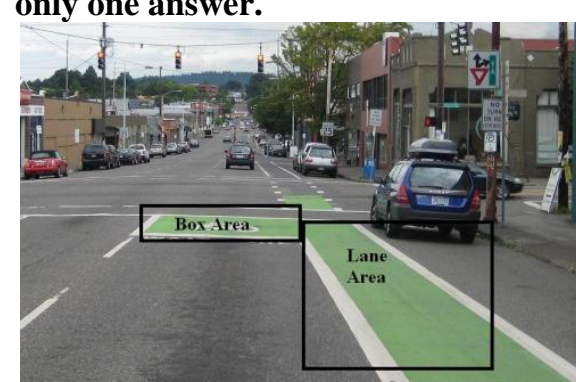

\begin{tabular}{|c|c|c|c|c|c|c|}
\hline & $\begin{array}{c}\text { SE } \\
\text { Hawthorne } \\
\text { at 7th }\end{array}$ & $\begin{array}{c}\text { NW } \\
\text { Broadway } \\
\text { at Hoyt }\end{array}$ & $\begin{array}{c}\text { SW } \\
\text { Broadway } \\
\text { at Taylor }\end{array}$ & $\begin{array}{c}\text { SW } \\
\text { Terwilliger } \\
\text { at Taylors } \\
\text { Ferry } \\
\end{array}$ & $\begin{array}{l}\text { SW 14 }{ }^{\text {th }} \text { at } \\
\text { Burnside }\end{array}$ & Total \\
\hline $\begin{array}{l}\text { Within the box area, } \\
\text { whether or not there are } \\
\text { other bikes around }\end{array}$ & 9.7 & 20.8 & 8.3 & 33.3 & 26.9 & 15.8 \\
\hline $\begin{array}{l}\text { Within the box area, but } \\
\text { only when there are other } \\
\text { bikes around }\end{array}$ & 19.4 & 12.4 & 8.3 & 0.0 & 3.8 & 14.9 \\
\hline In the bike lane area & 68.7 & 64.9 & 75 & 66.7 & 69.2 & 67.2 \\
\hline Neither & 0.5 & 0.5 & 0.0 & 0.0 & 0.0 & 0.4 \\
\hline I don't know & 1.8 & 1.5 & 8.3 & 0.0 & 0.0 & 1.7 \\
\hline Total & 100.0 & 100.0 & 100.0 & 100.0 & 100.0 & 100.0 \\
\hline $\mathrm{n}$ & 217 & 202 & 12 & 6 & 26 & 463 \\
\hline
\end{tabular}


As a bicyclist, are you allowed to legally turn right on a red light, after stopping, at this location?

\begin{tabular}{ll}
\hline & Percent \\
\hline Yes & 83.3 \\
No & 4.9 \\
I don't know & 11.8 \\
Total & 100.0 \\
$\mathrm{n}$ & 466 \\
\hline
\end{tabular}

Note: "Yes" is the correct response.

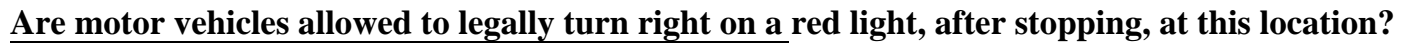

\begin{tabular}{ll} 
& Percent \\
\hline Yes & 38.1 \\
No & 40.5 \\
I don't know & 21.4 \\
Total & 100.0 \\
$\mathrm{n}$ & 467 \\
\hline
\end{tabular}

Note: "No" is the correct response.

Do you think the bike box has made the intersection safer or more dangerous for you as a cyclist?

\begin{tabular}{ll}
\hline & Percent \\
\hline A lot safer & 19.5 \\
A little safer & 57.3 \\
No Difference & 13.5 \\
A little more dangerous & 1.7 \\
I don't know & 7.9 \\
Total & 100.0 \\
$\mathrm{n}$ & 466 \\
\hline
\end{tabular}

Do you think the bike box has made the intersection easier or more difficult to use as a cyclist?

\begin{tabular}{ll}
\hline & Percent \\
\hline A lot easier & 15.9 \\
A little easier & 42.2 \\
No Difference & 30.3 \\
A little more difficult & 4.9 \\
A lot more difficult & .4 \\
I don't know & 6.2 \\
Total & 100.0 \\
$\mathrm{n}$ & 465 \\
\hline
\end{tabular}


Do you think most motorists understand the purpose of the bike box at this intersection?

\begin{tabular}{ll}
\hline & Percent \\
\hline Yes & 37.0 \\
No & 34.9 \\
I don't know & 28.1 \\
Total & 100.0 \\
$\mathrm{n}$ & 467 \\
\hline
\end{tabular}

While on your bicycle at this intersection, how often have you seen motor vehicles stopped at a red light partially or completely inside the bike box?

\begin{tabular}{ll} 
& Percent \\
\hline Never & 15.6 \\
Rarely, less than $10 \%$ of the time & 58.1 \\
Often, about $10-50 \%$ of the time & 23.9 \\
Very Often, more than half of the time & 2.4 \\
Total & 100.0 \\
$\mathrm{n}$ & 461 \\
\hline
\end{tabular}

Is there anything you think should be changed about the bike box at this intersection?

\begin{tabular}{ll} 
& Percent \\
\hline Yes & 39.9 \\
No & 28.8 \\
I don't know & 31.3 \\
Total & 100.0 \\
$\mathrm{n}$ & 466 \\
\hline
\end{tabular}

Has the installation of the bike box changed how you ride through this intersection?

\begin{tabular}{ll}
\hline & Percent \\
\hline No, I didn't ride through this intersection & 14.2 \\
before it was in & \\
No, I ride through it the same as before & 66.5 \\
Yes & 19.3 \\
Total & 100.0 \\
$\mathrm{n}$ & 466 \\
\hline
\end{tabular}

Have you ridden your bicycle through other intersections in Portland with bike boxes?

\begin{tabular}{ll}
\hline & Percent \\
\hline No, never & 1.9 \\
Yes, but not often & 30.4 \\
Yes, regularly & 65.7 \\
I don't know & 1.9 \\
Total & 100.0 \\
$\mathrm{n}$ & 467 \\
\hline
\end{tabular}


Please indicate whether you agree or disagree with the following statement: Motorists are more aware of cyclists because of the bike boxes in Portland.

\begin{tabular}{ll} 
& Percent \\
\hline Strongly disagree & 2.4 \\
Somewhat disagree & 8.3 \\
Neither & 5.6 \\
Somewhat agree & 56.4 \\
Strongly Agree & 24.6 \\
I don't know & 2.8 \\
Total & 100.0 \\
$\mathrm{n}$ & 468 \\
\hline
\end{tabular}

Please indicate whether you agree or disagree with the following statement: The bike boxes make for a better environment for bicycling in Portland.

\begin{tabular}{ll}
\hline & Percent \\
\hline Strongly disagree & 2.6 \\
Somewhat disagree & 5.1 \\
Neither & 6.2 \\
Somewhat agree & 46.4 \\
Strongly Agree & 36.8 \\
I don't know & 3.0 \\
Total & 100.0 \\
$\mathrm{n}$ & 468 \\
\hline
\end{tabular}

Do you think the City should install bike boxes at other intersections?

\begin{tabular}{ll}
\hline & Percent \\
\hline No & 7.1 \\
Yes & 72.4 \\
I don't know & 20.6 \\
Total & 100.0 \\
$\mathrm{n}$ & 467 \\
\hline
\end{tabular}

On average during summer months (June-September), how many days per month do you ride your bicycle?

\begin{tabular}{ll}
\hline & Percent \\
\hline Minimum & 2 \\
Maximum & 31 \\
Mean & 22.66 \\
Median & 24 \\
Mode & 20 \\
Standard Deviation & 6.68 \\
$\mathrm{n}$ & 465 \\
\hline
\end{tabular}


During the non-summer months, about how many days per month do you ride your bicycle?

\begin{tabular}{ll} 
& Percent \\
\hline Minimum & 1 \\
Maximum & 31 \\
Mean & 18.57 \\
Median & 20 \\
Mode & 20 \\
Standard Deviation & 7.82 \\
$\mathrm{n}$ & 459 \\
\hline
\end{tabular}

Which of these statements best describes your bicycling travel habits?

\begin{tabular}{ll}
\hline & Percent \\
\hline My bicycle is my main mode of transportation year-round & 56.4 \\
$\begin{array}{l}\text { My bicycle is my main mode of transportation during good weather. I drive or take } \\
\text { transit more when the weather is bad. }\end{array}$ & 21.4 \\
$\begin{array}{l}\text { I bicycle regularly for transportation (e.g. to work, school, shopping, errands), but it's not } \\
\text { my main mode. }\end{array}$ & 20.7 \\
$\begin{array}{l}\text { I rarely bicycle for transportation (e.g. to work, school, shopping errands) } \\
\text { I only bicycle for recreation or exercise, and not to get to places, such as work, school, }\end{array}$ & 1.1 \\
shopping, errands, etc. & 0.4 \\
Total & 100.0 \\
$\mathrm{n}$ & 468 \\
\hline
\end{tabular}

\begin{tabular}{ll} 
About how many years have you been bicycling regula \\
\hline & Percent \\
\hline 1 & 15.3 \\
2 & 14.8 \\
3 & 11.1 \\
4 & 7.4 \\
5 & 10.3 \\
6 & 4.8 \\
7 & 3.5 \\
8 & 4.4 \\
9 & 1.5 \\
$10+$ & 26.9 \\
Total & 100.0 \\
$\mathrm{n}$ & 458 \\
\hline
\end{tabular}


Please rate how comfortable you generally feel when cycling in heavy motor vehicle traffic.

\begin{tabular}{ll} 
& Percent \\
\hline Very uncomfortable & 10.1 \\
Somewhat uncomfortable & 28.5 \\
Neither & 3.0 \\
Somewhat comfortable & 37.0 \\
Very comfortable & 21.4 \\
Total & 100.0 \\
$\mathrm{n}$ & 467 \\
\hline
\end{tabular}

In the past five years, how many (if any) of the following types of crashes have you been involved in as a bicyclist? Include all crashes, not just those in the City of Portland.

\begin{tabular}{lcccccccccc}
\multicolumn{1}{c}{ Percent } & $\mathbf{0}$ & $\mathbf{1}$ & $\mathbf{2}$ & $\mathbf{3}$ & $\mathbf{4}$ & $\mathbf{5}$ & $\mathbf{6}$ & $\mathbf{7 +}$ & Total & $\mathbf{n}$ \\
\hline $\begin{array}{l}\text { Crash with a motor vehicle where I was not } \\
\text { injured }\end{array}$ & 76.8 & 14.7 & 6.6 & 1.3 & 0.4 & 0 & 0.2 & 0 & 100.0 & 457 \\
$\begin{array}{l}\text { If one or more, how many of these crashes } \\
\text { occurred at an intersection? }\end{array}$ & 24.5 & 51.9 & 19.8 & 1.9 & 1.9 & 0 & 0 & 0 & 100.0 & 106 \\
$\begin{array}{l}\text { Crash with a motor vehicle where I was } \\
\text { injured }\end{array}$ & 88.6 & 10.0 & 1.1 & 0.2 & 0 & 0 & 0 & 0 & 100.0 & 440 \\
If one or more, how many of these crashes & 34.0 & 60.0 & 6.0 & 0 & 0 & 0 & 0 & 0 & 100.0 & 50
\end{tabular}
occurred at an intersection?

Do you have a valid driver's license?

\begin{tabular}{ll}
\hline & Percent \\
\hline Yes & 97.0 \\
No & 3.0 \\
Total & 100.0 \\
$\mathrm{n}$ & 468 \\
\hline
\end{tabular}

On average, about how many miles per week do you drive any motor vehicle, including Zipcar (e.g. car, truck, van, motorcycle, SUV, etc.)?

\begin{tabular}{ll}
\hline & Percent \\
\hline Minimum & 0 \\
Maximum & 490 \\
Mean & 30.99 \\
Median & 20 \\
Mode & 10 \\
Standard Deviation & 47.42 \\
$\mathrm{n}$ & 448 \\
\hline
\end{tabular}


How many motor vehicles does your household own or lease? (Include motorcycles, cars, pick-up truck, vans, and SUVs, but not motorhomes, motor scooters, mopeds, or Zipcar).

\begin{tabular}{ll} 
& Percent \\
\hline Minimum & 0 \\
Maximum & 7 \\
Mean & 1.48 \\
Median & 1 \\
Mode & 1 \\
Standard Deviation & 0.88 \\
$\mathrm{n}$ & 451 \\
\hline
\end{tabular}

\begin{tabular}{ll} 
What is your age? & Percent \\
\hline Minimum & 15 \\
Maximum & 66 \\
Mean & 36.14 \\
Median & 34 \\
Mode & 28 \\
Standard Deviation & 9.35 \\
$\mathrm{n}$ & 465 \\
\hline
\end{tabular}

\section{What is your gender?}

\begin{tabular}{ll}
\hline & Percent \\
\hline Male & 61.9 \\
Female & 38.1 \\
Total & 100.0 \\
$\mathrm{n}$ & 457 \\
\hline
\end{tabular}

What is the highest grade or level of school you have completed?

\begin{tabular}{ll}
\hline & Percent \\
\hline Less than a high school diploma & 0.6 \\
High school Diploma or GED & 1.5 \\
Associate Degree (for example: AA, AS) or technical or vocational school & 2.4 \\
Some college, but no degree & 8.4 \\
Bachelor's degree (for example: BA, AB, BS) & 37.5 \\
Some graduate study, but no degree & 11.2 \\
Graduate or professional degree (Master's, professional, (e.g. law, medicine, doctorate) & 38.4 \\
Total & 100.0 \\
$\mathrm{n}$ & 464 \\
\hline
\end{tabular}


Are you currently...

Check as many as apply. :

\begin{tabular}{ll}
\hline & Percent \\
\hline Employed full-time & 82.3 \\
Employed part-time & 9.6 \\
Unemployed and looking for work & 2.6 \\
Retired & 0.4 \\
Going to school & 11.8 \\
Homemaker & 1.1 \\
Disabled and on disability, not working & 0.0 \\
Other & 1.1 \\
$\mathrm{n}$ & 468 \\
\hline
\end{tabular}

C-11 


\section{MOTORIST SURVEY RESPONSES}

During 2009, about how often have you driven a motor vehicle within the city limits of the City of Portland?

\begin{tabular}{lll}
\hline Never & $\begin{array}{c}\text { All } \\
\text { (Percent) }\end{array}$ & $\begin{array}{c}\text { Non- } \\
\text { Cyclists } \\
\text { (Percent) }\end{array}$ \\
Less than once a week & $.6 \%$ & $.0 \%$ \\
1-3 days per week & $11.1 \%$ & $10.0 \%$ \\
4 or more days per week & $29.4 \%$ & $21.5 \%$ \\
Total & $58.9 \%$ & $68.5 \%$ \\
$\mathrm{n}$ & $100.0 \%$ & $100.0 \%$ \\
\hline
\end{tabular}

Have you ever driven a motor vehicle through an intersection in the City of Portland with a pavement marking, as shown in the photos below?

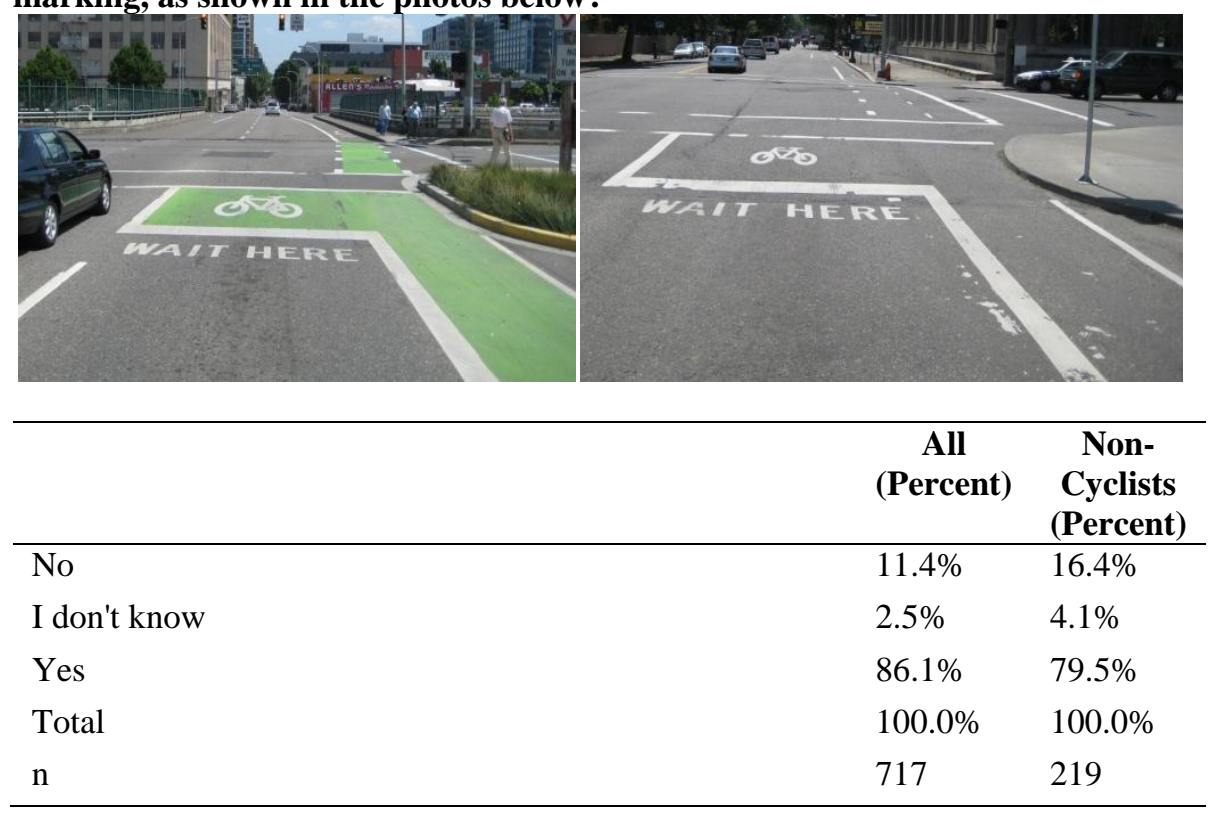


If you approached an intersection with a red light and there were no bicycles at the intersection, where should you stop your car to wait for the green light? Please refer to Figure A and Figure B.

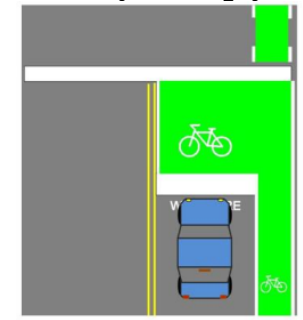

Figure A

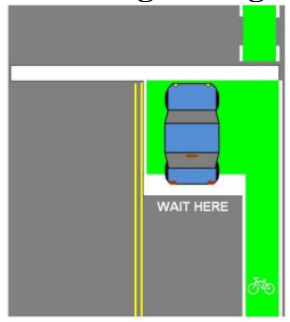

Figure B

\begin{tabular}{ll}
$\begin{array}{c}\text { All } \\
\text { Percent) }\end{array}$ & $\begin{array}{c}\text { Non- } \\
\text { Cyclists } \\
\text { (Percent) }\end{array}$ \\
\hline $94.1 \%$ & $92.2 \%$ \\
$2.1 \%$ & $2.3 \%$ \\
$7 \%$ & $.5 \%$ \\
$3.1 \%$ & $5.0 \%$ \\
$00.0 \%$ & $100.0 \%$ \\
717 & 219
\end{tabular}

Note: "Figure A" is correct.

If you approached an intersection with a red light and there was a bicycle, as shown in Figure A and Figure $B$, where should you stop your car to wait for the green light?

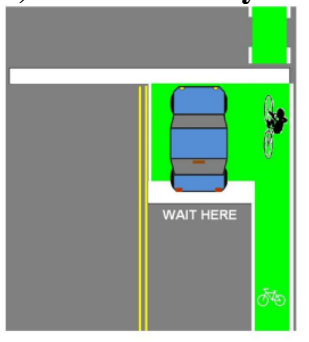

Figure A

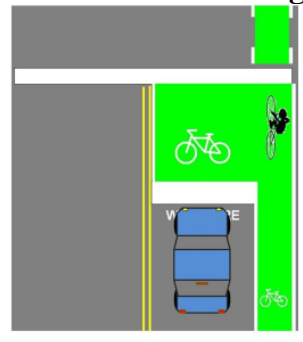

Figure B

\begin{tabular}{llc}
\multicolumn{1}{c}{ Figure A } & Figure B & All \\
& $\begin{array}{c}\text { Non- } \\
\text { Cyclists } \\
\text { (Percent) }\end{array}$ & $\begin{array}{c}\text { Cycent) } \\
\text { (Percent }\end{array}$ \\
\hline Figure A & $9.3 \%$ & $11.9 \%$ \\
Figure B & $89.4 \%$ & $86.3 \%$ \\
Figure A or Figure B & $4 \%$ & $.5 \%$ \\
I don't know & $.8 \%$ & $1.4 \%$ \\
Total & $100.0 \%$ & $100.0 \%$ \\
n & 717 & 219 \\
\hline
\end{tabular}

Note: "Figure A" is correct. 
In the picture below, the white car is waiting at a red light. Is the car stopped in the correct location?

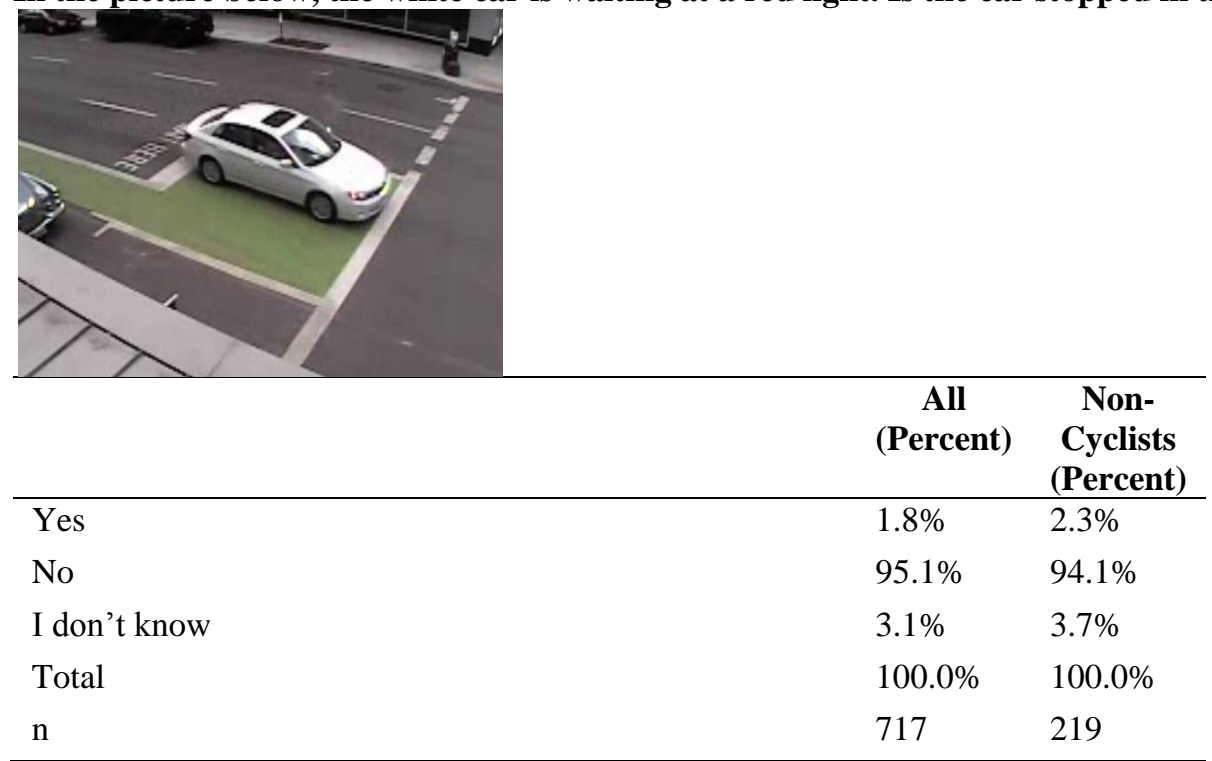

Note: "No" is the correct answer.

In the picture below, the white SUV and the bicycle are waiting at a red light. Is the SUV stopped in the correct location?

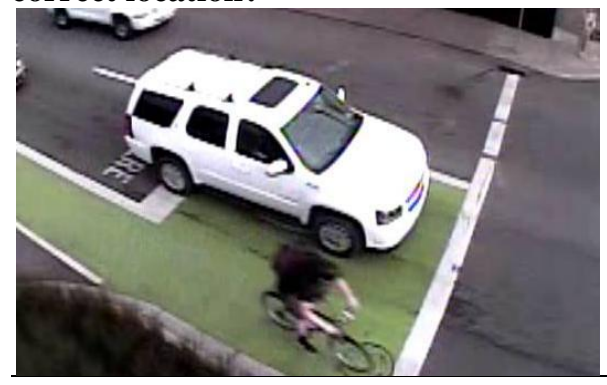

\begin{tabular}{lll}
\hline & \multicolumn{1}{c}{$\begin{array}{c}\text { All } \\
\text { (Percent) }\end{array}$} & $\begin{array}{c}\text { Non- } \\
\text { Cyclists } \\
\text { (Percent) }\end{array}$ \\
\hline Yes & $.6 \%$ & $.5 \%$ \\
No & $98.3 \%$ & $98.2 \%$ \\
I don't know & $1.1 \%$ & $1.4 \%$ \\
Total & $100.0 \%$ & $100.0 \%$ \\
n & 717 & 219
\end{tabular}

Note: "No" is the correct answer. 
The pavement markings in the previous photos are called "bike boxes." Looking at the photo below, imagine that you are driving a car in the same lane as the bicyclist. The light is green and you plan on driving straight. Are you supposed to change lanes to the left to avoid driving in the bike box?

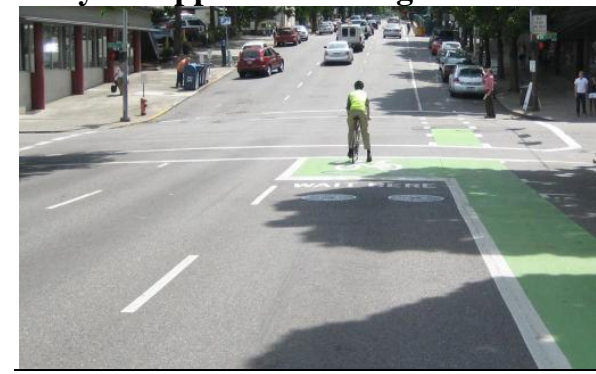

\begin{tabular}{lll}
\hline & \multicolumn{1}{c}{$\begin{array}{c}\text { All } \\
\text { (Percent) }\end{array}$} & $\begin{array}{c}\text { Non- } \\
\text { Cyclists } \\
\text { (Percent) }\end{array}$ \\
\hline Yes & $5.4 \%$ & $9.1 \%$ \\
No & $86.1 \%$ & $77.6 \%$ \\
I don't know & $8.5 \%$ & $13.2 \%$ \\
Total & $100.0 \%$ & $100.0 \%$ \\
$\mathrm{n}$ & 717 & 219 \\
\hline
\end{tabular}

Note: "No" is the correct answer.

About how often have you driven a motor vehicle through a City of Portland intersection with a bike box, in the direction of the bike box (e.g. driving in the lane with the box or the lane(s) next to it)?

\begin{tabular}{lll}
\hline & $\begin{array}{c}\text { All } \\
\text { (Percent) }\end{array}$ & $\begin{array}{c}\text { Non- } \\
\text { Cyclists } \\
\text { (Percent) }\end{array}$ \\
\hline Never & $10.2 \%$ & $14.2 \%$ \\
Only once & $3.6 \%$ & $3.7 \%$ \\
More than once, but less than 10 times & $26.6 \%$ & $27.4 \%$ \\
More than 10 times & $52.7 \%$ & $42.5 \%$ \\
I don't know & $6.8 \%$ & $12.3 \%$ \\
Total & $100.0 \%$ & $100.0 \%$ \\
$\mathrm{n}$ & 717 & 219 \\
\hline
\end{tabular}

When you have driven through Portland intersections with bike boxes, did you see any traffic signs about the bike box at the intersection?

\begin{tabular}{lll}
\hline & $\begin{array}{c}\text { All } \\
\text { (Percent) }\end{array}$ & $\begin{array}{c}\text { Non- } \\
\text { Cyclists } \\
\text { (Percent) }\end{array}$ \\
\hline Yes & $17.9 \%$ & $13.3 \%$ \\
No & $43.9 \%$ & $44.7 \%$ \\
I don't know & $38.2 \%$ & $42.0 \%$ \\
Total & $100.0 \%$ & $100.0 \%$ \\
$\mathrm{n}$ & 644 & $17.9 \%$ \\
\hline
\end{tabular}


In the past year, do you remember seeing any billboards in the City of Portland about bike boxes?

\begin{tabular}{lll}
\hline & $\begin{array}{c}\text { All } \\
\text { (Percent) }\end{array}$ & $\begin{array}{c}\text { Non- } \\
\text { Cyclists } \\
\text { (Percent) }\end{array}$ \\
\hline Yes & $25.2 \%$ & $21.0 \%$ \\
No & $57.6 \%$ & $61.2 \%$ \\
I don't know & $17.2 \%$ & $17.8 \%$ \\
Total & $100.0 \%$ & $100.0 \%$ \\
$\mathrm{n}$ & 717 & 219 \\
\hline
\end{tabular}

There are two types of bike boxes in the City of Portland, both shown in the photos below. As a driver, do you think one of the pavement marking designs is better than the other?

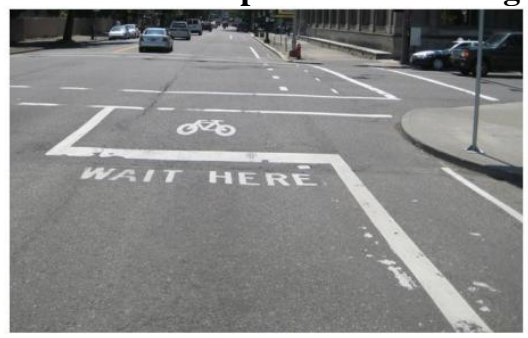

Figure A

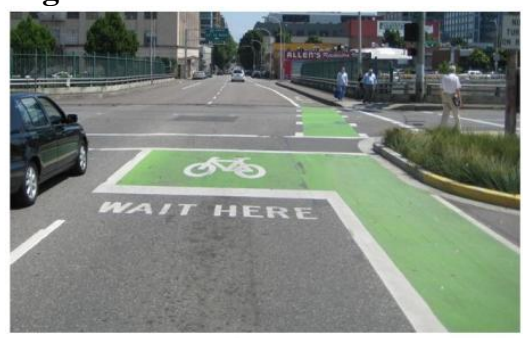

Figure B

\begin{tabular}{lll}
\hline & $\begin{array}{c}\text { All } \\
\text { (Percent) }\end{array}$ & $\begin{array}{c}\text { Non- } \\
\text { Cyclists } \\
\text { (Percent) }\end{array}$ \\
\hline The pavement marking in Figure A is better than in Figure B & $5.6 \%$ & $5.5 \%$ \\
The pavement marking in Figure B is better than in Figure A & $89.3 \%$ & $90.0 \%$ \\
Both are about the same & $4.6 \%$ & $4.1 \%$ \\
I don't know & $.6 \%$ & $.5 \%$ \\
Total & $100.0 \%$ & $100.0 \%$ \\
$\mathrm{n}$ & 717 & 219 \\
\hline
\end{tabular}

Do you think the bike box has made driving safer or more dangerous at the intersections where they are installed? Choose only one answer

\begin{tabular}{lll}
\hline & $\begin{array}{c}\text { All } \\
\text { (Percent) }\end{array}$ & $\begin{array}{c}\text { Non- } \\
\text { Cyclists } \\
\text { (Percent) }\end{array}$ \\
\hline A lot safer & $16.2 \%$ & $12.8 \%$ \\
A little safer & $35.8 \%$ & $29.2 \%$ \\
No difference & $18.1 \%$ & $16.9 \%$ \\
A little more dangerous & $9.1 \%$ & $10.5 \%$ \\
A lot more dangerous & $2.8 \%$ & $3.7 \%$ \\
I don't know & $18.0 \%$ & $26.9 \%$ \\
Total & $100.0 \%$ & $100.0 \%$ \\
$\mathrm{n}$ & 717 & 219 \\
\hline
\end{tabular}


About how often have you ridden a bicycle through a City of Portland intersection with a bike box, in the direction of the bike box?

\begin{tabular}{lll}
\hline & \multicolumn{1}{c}{$\begin{array}{c}\text { All } \\
\text { (Percent) }\end{array}$} & $\begin{array}{c}\text { Non- } \\
\text { Cyclists } \\
\text { (Percent) }\end{array}$ \\
\hline Never & $68.3 \%$ & $97.7 \%$ \\
Only once & $3.2 \%$ & $.0 \%$ \\
More than once, but less than 10 times & $11.7 \%$ & $.5 \%$ \\
More than 10 times & $15.3 \%$ & $.0 \%$ \\
I don't know & $1.4 \%$ & $1.8 \%$ \\
Total & $100.0 \%$ & $100.0 \%$ \\
$\mathrm{n}$ & 717 & 219 \\
\hline
\end{tabular}

Do you think the bike boxes have made bicycling safer or more dangerous at the intersections where they are installed? Choose only one answer

\begin{tabular}{lll}
\hline & $\begin{array}{c}\text { All } \\
\text { (Percent) }\end{array}$ & $\begin{array}{c}\text { Non- } \\
\text { Cyclists } \\
\text { (Percent) }\end{array}$ \\
\hline A lot safer & $19.0 \%$ & $17.4 \%$ \\
A little safer & $39.9 \%$ & $30.1 \%$ \\
No difference & $13.4 \%$ & $14.6 \%$ \\
A little more dangerous & $6.1 \%$ & $7.3 \%$ \\
A lot more dangerous & $1.7 \%$ & $1.4 \%$ \\
I don't know & $19.9 \%$ & $29.2 \%$ \\
Total & $100.0 \%$ & $100.0 \%$ \\
$\mathrm{n}$ & 717 & 219 \\
\hline
\end{tabular}

Do you think motorists drive more safely because of the bike boxes?

\begin{tabular}{lll}
\hline & $\begin{array}{c}\text { All } \\
\text { (Percent) }\end{array}$ & $\begin{array}{c}\text { Non- } \\
\text { Cyclists } \\
\text { (Percent) }\end{array}$ \\
\hline Yes & $44.1 \%$ & $37.0 \%$ \\
No & $20.9 \%$ & $21.0 \%$ \\
I don't know & $35.0 \%$ & $42.0 \%$ \\
Total & $100.0 \%$ & $100.0 \%$ \\
$\mathrm{n}$ & 717 & 219 \\
\hline
\end{tabular}

Do you think bicyclists ride more safely because of the bike boxes?

\begin{tabular}{lll}
\hline & $\begin{array}{c}\text { All } \\
\text { (Percent) }\end{array}$ & $\begin{array}{c}\text { Non- } \\
\text { Cyclists } \\
\text { (Percent) }\end{array}$ \\
\hline Yes & $28.2 \%$ & $22.8 \%$ \\
No & $40.0 \%$ & $40.2 \%$ \\
I don't know & $31.8 \%$ & $37.0 \%$ \\
Total & $100.0 \%$ & $100.0 \%$ \\
$\mathrm{n}$ & 717 & 219 \\
\hline
\end{tabular}


Do you think the bike boxes have made driving more or less convenient at the intersections where they are installed? Choose only one answer

\begin{tabular}{lll}
\hline & $\begin{array}{c}\text { All } \\
\text { (Percent) }\end{array}$ & $\begin{array}{c}\text { Non- } \\
\text { Cyclists } \\
\text { (Percent) }\end{array}$ \\
\hline A lot more convenient & $3.3 \%$ & $3.2 \%$ \\
A little more convenient & $7.5 \%$ & $6.4 \%$ \\
No difference & $41.3 \%$ & $38.8 \%$ \\
A little less convenient & $31.2 \%$ & $30.1 \%$ \\
A lot less convenient & $9.5 \%$ & $11.4 \%$ \\
I don't know & $7.1 \%$ & $10.0 \%$ \\
Total & $100.0 \%$ & $100.0 \%$ \\
$\mathrm{n}$ & 717 & 219 \\
\hline
\end{tabular}

Do you think the bike boxes have made you feel more comfortable driving through the intersections when bicyclists are nearby? Choose only one answer

\begin{tabular}{lll}
\hline & \multicolumn{1}{c}{$\begin{array}{c}\text { All } \\
\text { (Percent) }\end{array}$} & $\begin{array}{c}\text { Non- } \\
\text { Cyclists } \\
\text { (Percent) }\end{array}$ \\
\hline A lot more comfortable & $12.3 \%$ & $10.5 \%$ \\
A little more comfortable & $29.8 \%$ & $22.4 \%$ \\
No difference & $37.5 \%$ & $41.1 \%$ \\
A little less comfortable & $8.9 \%$ & $11.0 \%$ \\
A lot less comfortable & $5.6 \%$ & $5.5 \%$ \\
I don't know & $5.9 \%$ & $9.6 \%$ \\
Total & $100.0 \%$ & $100.0 \%$ \\
$\mathrm{n}$ & 717 & 219 \\
\hline
\end{tabular}

Has the installation of the bike boxes changed how you drive through the intersections with bike boxes?

\begin{tabular}{lll}
\hline No & $\begin{array}{c}\text { All } \\
\text { (Percent) }\end{array}$ & $\begin{array}{c}\text { Non- } \\
\text { Cyclists } \\
\text { (Percent) }\end{array}$ \\
Yes & $29.9 \%$ & $30.7 \%$ \\
Total & $70.1 \%$ & $69.3 \%$ \\
$\mathrm{n}$ & $100.0 \%$ & $100.0 \%$ \\
\hline
\end{tabular}

Has the installation of the bike boxes changed how you drive through intersections without bike boxes?

\begin{tabular}{lll}
\hline & $\begin{array}{c}\text { All } \\
\text { (Percent) }\end{array}$ & $\begin{array}{c}\text { Non- } \\
\text { Cyclists } \\
\text { (Percent) }\end{array}$ \\
\hline No & $76.4 \%$ & $77.0 \%$ \\
Yes & $23.6 \%$ & $23.0 \%$ \\
Total & $100.0 \%$ & $100.0 \%$ \\
$\mathrm{n}$ & 713 & 217 \\
\hline
\end{tabular}


On streets and traffic signs, different colors often have a particular meaning. What, if any, color(s) on roads and signs do you associate with bicycles or bicycling? Check all that apply

\begin{tabular}{lll}
\hline & $\begin{array}{c}\text { All } \\
\text { (Percent) }\end{array}$ & $\begin{array}{c}\text { Non- } \\
\text { Cyclists } \\
\text { (Percent) }\end{array}$ \\
\hline None & $4.3 \%$ & $6.8 \%$ \\
Blue & $3.1 \%$ & $1.8 \%$ \\
Green & $17.1 \%$ & $15.1 \%$ \\
Orange & $.1 \%$ & $.0 \%$ \\
Red & $.8 \%$ & $.9 \%$ \\
Yellow & $2.5 \%$ & $.9 \%$ \\
Other (please specify) & $.4 \%$ & $.0 \%$ \\
$\mathrm{n}$ & 721 & 219 \\
\hline
\end{tabular}

Please indicate whether you agree or disagree with the following statement: The City of Portland should be doing more to improve bicycle safety.

\begin{tabular}{lll}
\hline & \multicolumn{1}{c}{$\begin{array}{c}\text { All } \\
\text { (Percent) }\end{array}$} & $\begin{array}{c}\text { Non- } \\
\text { Cyclists } \\
\text { (Percent) }\end{array}$ \\
\hline Strongly disagree & $8.7 \%$ & $11.5 \%$ \\
Somewhat disagree & $7.0 \%$ & $9.6 \%$ \\
Somewhat agree & $40.7 \%$ & $46.2 \%$ \\
Strongly agree & $37.2 \%$ & $21.2 \%$ \\
No opinion & $6.4 \%$ & $11.5 \%$ \\
Total & $100.0 \%$ & $100.0 \%$ \\
$\mathrm{n}$ & 172 & 52 \\
\hline
\end{tabular}

Do you think the bike boxes make drivers more aware of bicyclists generally, not just at the intersections?

\begin{tabular}{lll}
\hline & $\begin{array}{c}\text { All } \\
\text { (Percent) }\end{array}$ & $\begin{array}{c}\text { Non- } \\
\text { Cyclists } \\
\text { (Percent) }\end{array}$ \\
\hline No & $18.1 \%$ & $20.1 \%$ \\
Yes & $58.9 \%$ & $52.1 \%$ \\
I don't know & $23.0 \%$ & $27.9 \%$ \\
Total & $100.0 \%$ & $100.0 \%$ \\
$\mathrm{n}$ & 717 & 219 \\
\hline
\end{tabular}


Do you agree or disagree with the following statement: Many bicyclists disobey traffic laws, causing problems for motorists and traffic.

\begin{tabular}{lll} 
& \multicolumn{1}{c}{$\begin{array}{c}\text { All } \\
\text { (Percent) }\end{array}$} & $\begin{array}{c}\text { Non- } \\
\text { Cyclists } \\
\text { (Percent) }\end{array}$ \\
\hline Strongly agree & $35.7 \%$ & $42.5 \%$ \\
Somewhat agree & $44.9 \%$ & $43.4 \%$ \\
Neither & $5.6 \%$ & $6.4 \%$ \\
Somewhat disagree & $9.1 \%$ & $5.5 \%$ \\
Strongly disagree & $3.5 \%$ & $.5 \%$ \\
I don't know & $1.3 \%$ & $1.8 \%$ \\
Total & $100.0 \%$ & $100.0 \%$ \\
$\mathrm{n}$ & 717 & 219 \\
\hline
\end{tabular}

Do you think the City should install bike boxes at other intersections or remove them from some intersections?

\begin{tabular}{lll}
\hline & $\begin{array}{c}\text { All } \\
\text { (Percent) }\end{array}$ & $\begin{array}{c}\text { Non- } \\
\text { Cyclists } \\
\text { (Percent) }\end{array}$ \\
\hline The City should install more bike boxes & $46.2 \%$ & $38.4 \%$ \\
The City should remove some or all of the bike boxes & $11.2 \%$ & $11.0 \%$ \\
Neither. The City should not install more bike boxes or & $18.0 \%$ & $20.1 \%$ \\
remove any of the existing ones & $24.7 \%$ & $30.6 \%$ \\
I don't know & $100.0 \%$ & $100.0 \%$ \\
Total & 717 & 219 \\
$\mathrm{n}$ & & \\
\hline
\end{tabular}

Do you agree or disagree with the following statement: The City of Portland should be doing more to increase the number of people bicycling

\begin{tabular}{lll}
\hline & \multicolumn{1}{c}{$\begin{array}{c}\text { All } \\
\text { (Percent) }\end{array}$} & $\begin{array}{c}\text { Non- } \\
\text { Cyclists } \\
\text { (Percent) }\end{array}$ \\
\hline Strongly disagree & $9.4 \%$ & $10.1 \%$ \\
Somewhat disagree & $11.9 \%$ & $15.1 \%$ \\
Somewhat agree & $33.9 \%$ & $33.9 \%$ \\
Strongly agree & $24.3 \%$ & $8.7 \%$ \\
No opinion & $20.5 \%$ & $32.1 \%$ \\
Total & $100.0 \%$ & $100.0 \%$ \\
$\mathrm{n}$ & 716 & 218 \\
\hline
\end{tabular}


In the past few years in Portland, do you remember reading or hearing about any motor vehicles turning right and hitting a bicyclist?

\begin{tabular}{lll}
\hline & \multicolumn{1}{c}{$\begin{array}{c}\text { All } \\
\text { (Percent) }\end{array}$} & $\begin{array}{c}\text { Non- } \\
\text { Cyclists } \\
\text { (Percent) }\end{array}$ \\
\hline No & $7.4 \%$ & $11.9 \%$ \\
Yes & $87.3 \%$ & $80.4 \%$ \\
I don't know & $5.3 \%$ & $7.8 \%$ \\
Total & $100.0 \%$ & $100.0 \%$ \\
$\mathrm{n}$ & 716 & 219 \\
\hline
\end{tabular}

As a driver, have you ever been involved in a crash with a bicyclist?

\begin{tabular}{lll}
\hline & $\begin{array}{c}\text { All } \\
\text { (Percent) }\end{array}$ & $\begin{array}{c}\text { Non- } \\
\text { Cyclists } \\
\text { (Percent) }\end{array}$ \\
\hline No & $95.8 \%$ & $95.9 \%$ \\
Yes & $3.9 \%$ & $3.7 \%$ \\
I don't know & $.3 \%$ & $.5 \%$ \\
Total & $100.0 \%$ & $100.0 \%$ \\
$\mathrm{n}$ & 714 & 218 \\
\hline
\end{tabular}

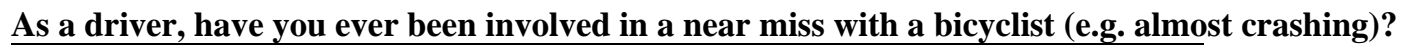

\begin{tabular}{lll}
\hline & $\begin{array}{c}\text { All } \\
\text { (Percent) }\end{array}$ & $\begin{array}{c}\text { Non- } \\
\text { Cyclists } \\
\text { (Percent) }\end{array}$ \\
\hline No & $53.2 \%$ & $54.3 \%$ \\
Yes & $45.0 \%$ & $42.9 \%$ \\
I don't know & $1.8 \%$ & $2.7 \%$ \\
Total & $100.0 \%$ & $100.0 \%$ \\
n & 713 & 219 \\
\hline
\end{tabular}

As a bicyclist, have you ever been involved in a crash with a motor vehicle?

\begin{tabular}{lll}
\hline \multicolumn{1}{|c}{ As a bicyclist, have you ever been involved in a crash with a motor vehicle? } & $\begin{array}{c}\text { All } \\
\text { (Percent) }\end{array}$ & $\begin{array}{c}\text { Non- } \\
\text { Cyclists } \\
\text { (Percent) }\end{array}$ \\
\hline No, I do not bicycle & $43.7 \%$ & $88.0 \%$ \\
No, I bicycle, but have not been in a crash with a motor vehicle & $43.0 \%$ & $6.9 \%$ \\
Yes & $12.3 \%$ & $2.8 \%$ \\
I don't know & $1.1 \%$ & $2.3 \%$ \\
Total & $100.0 \%$ & $100.0 \%$ \\
n & 710 & 216 \\
\hline
\end{tabular}


Do you own a working bicycle?

\begin{tabular}{lll}
\hline No & $\begin{array}{c}\text { All } \\
\text { (Percent) }\end{array}$ & $\begin{array}{c}\text { Non- } \\
\text { Cyclists } \\
\text { (Percent) }\end{array}$ \\
\hline Yes & $23.2 \%$ & $75.8 \%$ \\
Total & $76.8 \%$ & $24.2 \%$ \\
$\mathrm{n}$ & $100.0 \%$ & $100.0 \%$ \\
\hline
\end{tabular}

On average during summer months (June-September), how many days per month do you ride your bicycle?

\begin{tabular}{lll}
\hline & All & $\begin{array}{c}\text { Non- } \\
\text { Cyclists }\end{array}$ \\
\hline Minimum & 0 & 0 \\
Maximum & 31 & 13 \\
Mean & 6.64 & 0.23 \\
Median & 3 & 0 \\
Mode & 0 & 0 \\
$\mathrm{n}$ & 699 & 202 \\
\hline
\end{tabular}

During the non-summer months, about how many days per month do you ride your bicycle?

\begin{tabular}{lll}
\hline Minimum & All & $\begin{array}{c}\text { Non- } \\
\text { Cyclists }\end{array}$ \\
Maximum & 0 & 0 \\
Mean & 28 & 13 \\
Median & 2.21 & 0.10 \\
Mode & 0 & 0 \\
$\mathrm{n}$ & 0 & 0 \\
\hline
\end{tabular}

On average, about how many miles per week do you drive a motor vehicle (e.g. car, truck, van, motorcycle, SUV, etc.)?

\begin{tabular}{lll}
\hline & All & $\begin{array}{c}\text { Non- } \\
\text { Cyclists }\end{array}$ \\
\hline Minimum & 0 & 0 \\
Maximum & 600 & 600 \\
Mean & 85.90 & 92.85 \\
Median & 50 & 50 \\
Mode & 100 & 0 \\
N & 701 & 212 \\
\hline
\end{tabular}


What is your age?

\begin{tabular}{|c|c|c|}
\hline & All & $\begin{array}{c}\text { Non- } \\
\text { Cyclists }\end{array}$ \\
\hline Minimum & 21 & 21 \\
\hline Maximum & 72 & 72 \\
\hline Mean & 39.94 & 42.22 \\
\hline Median & 50 & 45 \\
\hline Mode & 39 & 52 \\
\hline $\mathrm{N}$ & 701 & 219 \\
\hline \multicolumn{3}{|c|}{ What is your gender? } \\
\hline & $\begin{array}{c}\text { All } \\
\text { (Percent) }\end{array}$ & $\begin{array}{c}\text { Non- } \\
\text { Cyclists } \\
\text { (Percent) }\end{array}$ \\
\hline Male & $26.9 \%$ & $16.7 \%$ \\
\hline Female & $73.1 \%$ & $83.3 \%$ \\
\hline Total & $100.0 \%$ & $100.0 \%$ \\
\hline $\mathrm{n}$ & 702 & 216 \\
\hline
\end{tabular}

What is the highest grade or level of school you have completed?

\begin{tabular}{lll}
\hline & \multicolumn{1}{c}{$\begin{array}{c}\text { All } \\
\text { (Percent) }\end{array}$} & $\begin{array}{c}\text { Non- } \\
\text { Cyclists } \\
\text { (Percent) }\end{array}$ \\
\hline High school Diploma or GED & $3.8 \%$ & $5.0 \%$ \\
Associate Degree (for example: AA, AS) or technical or vocational school & $8.5 \%$ & $10.1 \%$ \\
Some college, but no degree & $18.3 \%$ & $23.9 \%$ \\
Bachelor's degree (for example: BA, AB, BS) & $32.1 \%$ & $27.5 \%$ \\
Some graduate study, but no degree & $7.7 \%$ & $5.0 \%$ \\
Graduate or professional degree (Master's, professional, (e.g. law, & $29.6 \%$ & $28.4 \%$ \\
medicine), doctorate) & $100.0 \%$ & $100.0 \%$ \\
Total & 710 & 218 \\
\hline $\mathrm{n}$ & & \\
\hline
\end{tabular}

Are you currently... Check as many as apply:

\begin{tabular}{lll}
\hline & $\begin{array}{c}\text { All } \\
\text { (Percent) }\end{array}$ & $\begin{array}{c}\text { Non- } \\
\text { Cyclists } \\
\text { (Percent) }\end{array}$ \\
\hline Employed full-time & $91.7 \%$ & $95.0 \%$ \\
Employed part-time & $5.3 \%$ & $3.7 \%$ \\
Unemployed and looking for work & $1.1 \%$ & $.5 \%$ \\
Retired & $.3 \%$ & $.0 \%$ \\
Going to school & $3.7 \%$ & $1.8 \%$ \\
Homemaker & $1.2 \%$ & $.9 \%$ \\
Disabled and on disability, not working & $.1 \%$ & $.5 \%$ \\
Other & $.8 \%$ & $1.4 \%$ \\
$\mathrm{n}$ & 721 & 219 \\
\hline
\end{tabular}


C-24 



\section{SOTREC \\ AND EDUCATION CONSORTIUM}

P.O. Box 751

Portland, OR 97207

OTREC is dedicated to stimulating and conducting collaborative multi-disciplinary research on multi-modal surface transportation issues, educating a diverse array of current practitioners and future leaders in the transportation field, and encouraging implementation of relevant research results. 